Environmental Security Technology Certification Program

\title{
Treatability Study for Biologically Active Zone Enhancement (BAZE) for In Situ RDX Degradation in Groundwater
}

Altaf H. Wani, Brenda R. O'Neal, Jeffrey L. Davis,

October 2002 and Lance D. Hansen

US Army Corps of Engineers ${ }_{\circledast}$

Engineer Research and Development Center

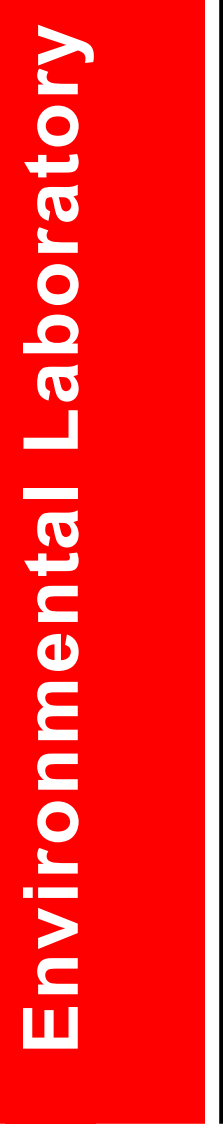


The contents of this report are not to be used for advertising, publication, or promotional purposes. Citation of trade names does not constitute an official endorsement or approval of the use of such commercial products.

The findings of this report are not to be construed as an official Department of the Army position, unless so designated by other authorized documents. 


\title{
Treatability Study for Biologically Active Zone Enhancement (BAZE) for In Situ RDX Degradation in Groundwater
}

\author{
by Altaf H. Wani, Brenda R. O'Neal \\ Applied Research Associates \\ Southern Division \\ 112 Monument Place \\ Vicksburg, MS 39180 \\ Jeffrey L. Davis, Lance D. Hansen \\ Environmental Laboratory \\ U.S. Army Engineer Research and Development Center \\ 3909 Halls Ferry Road \\ Vicksburg, MS 39180-6199
}

Final report

Approved for public release; distribution is unlimited 


\section{Contents}

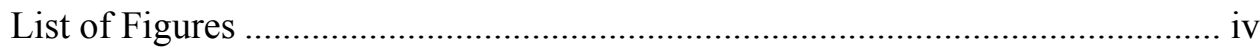

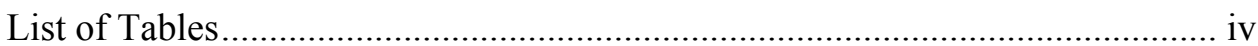

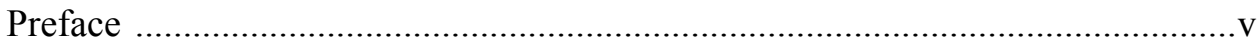

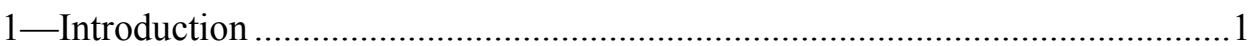

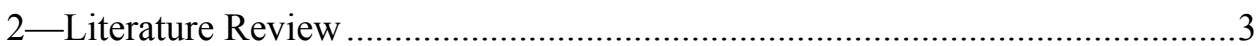

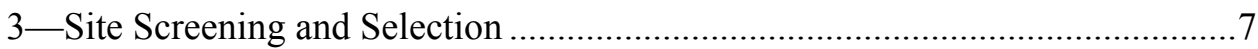

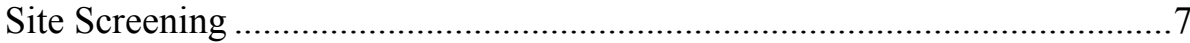

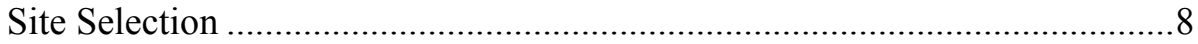

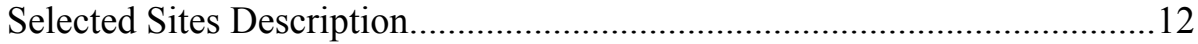

Nebraska Ordnance Plant (NOP) ...........................................................12

Cornhusker Army Ammunition Plant (CHAAP) ....................................13

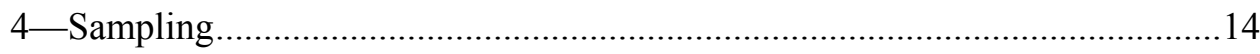

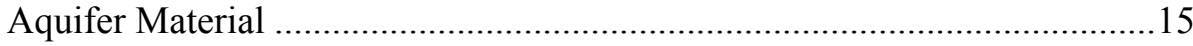

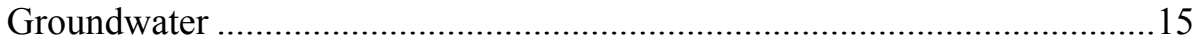

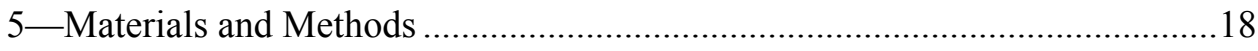

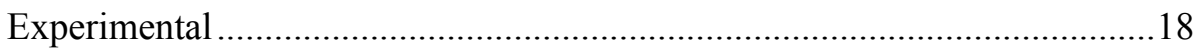

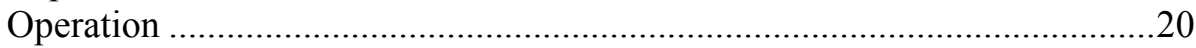

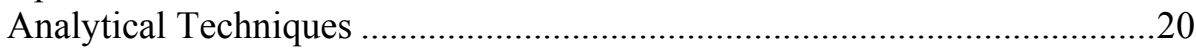

Hydrodynamics and Biodegradation Kinetics ...........................................21

Toxicological Analysis ...........................................................................23

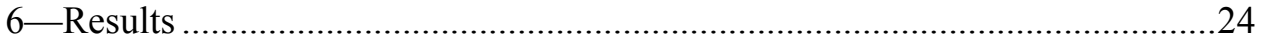

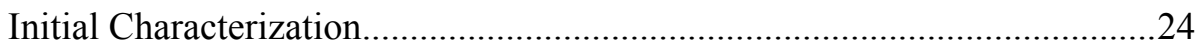

Column Hydrodynamics ......................................................................24

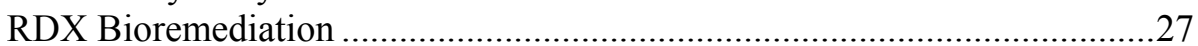

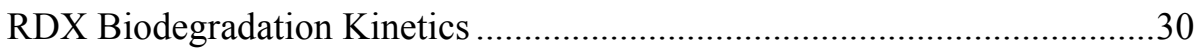

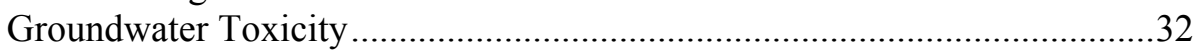

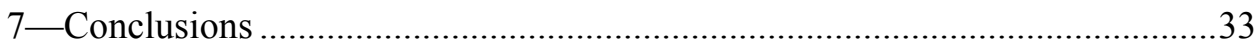

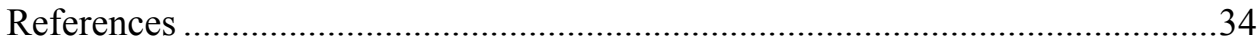

Appendix A: Site Screening Process ...............................................................

Appendix B: Plots of Results for Individual Columns ....................................... B1

SF 298 


\section{List of Figures}

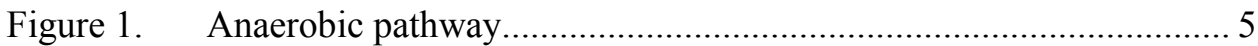

Figure 2. Location of selected sites............................................................... 11

Figure 3. Sampling location at NOP site ..................................................... 14

Figure 4. Sampling location at CHAAP site.................................................. 15

Figure 5. Direct-push sampling device .......................................................... 16

Figure 6. Aquifer material in acetate liners.................................................. 16

Figure 7. Site groundwater in 55-gal drums ................................................. 17

Figure 8. Schematics of column setup ......................................................... 19

Figure 9. Experimental column setup ........................................................ 19

Figure 10. Chloride tracer breakthrough curve for NOP

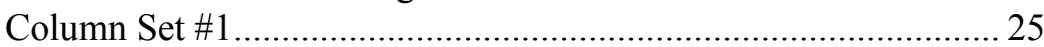

Figure 11. Hydraulic conductivity of NOP aquifer material

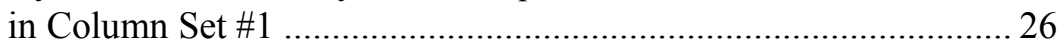

Figure 12. Column operating parameters for NOP Column Set \#1 ................. 28

Figure 13. RDX removal from NOP groundwater amended with acetate (Acetate concentration $=500 \mathrm{mg} \mathrm{L}^{-1}$ as $\mathrm{C}$ ) .

Figure 14. RDX biodegradation kinetics in NOP aquifer material (Column Set \#1)

\section{List of Tables}

Table 1. Criteria for Site Screening ........................................................... 7

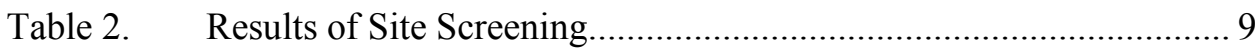

Table 3. Selection Criteria......................................................................... 9

Table 4. Summary of Selection Process ........................................................ 11

Table 5. Operating Conditions …................................................................ 20

Table 6. Initial Characterization of Groundwater ......................................... 24

Table 7. Porosity and Diffusivity of Aquifer Material in Each Column........ 26

Table 8. Hydraulic Conductivity of Aquifer Material in Each Column......... 27

Table 9. Biodegradation Kinetics of RDX in NOP and CHAAP Aquifer

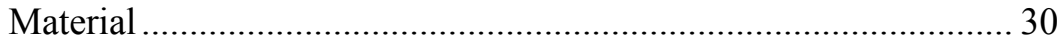

Table 10. Toxicity Levels of Influent and Effluent from Each Column.......... 32 


\section{Preface}

The work reported here is the first phase of a 4-year field demonstration project. The purpose of this treatability study was to determine the suitability of either Nebraska Ordnance Plant (NOP), Mead, NE, or Cornhusker Army Ammunition Plant (CHAAP), Grand Island, NE, for pilot-scale demonstration/ validation of in situ remediation of hexahydro-1,3,5-trinitro-1,3,5-triazine (RDX) contaminated groundwater under the Environmental Security Technology Certification Program (ESTCP). A series of column studies were conducted using site-specific soil and groundwater to determine the feasibility of using the biologically active zone enhancement (BAZE) process to remediate RDXcontaminated groundwater.

The work reported herein was conducted at the U.S. Army Engineer Research and Development Center (ERDC), Vicksburg, MS. The funding for this project was provided by the ESTCP under project ESTCP CU-0110.

This report was prepared by Dr. Altaf Wani and Ms. Brenda O'Neal, Applied Research Associates (ARA), Inc., Vicksburg, MS; and Dr. Jeffrey Davis and Mr. Lance D. Hansen, Environmental Laboratory (EL), ERDC. Chemical analyses were performed by the Environmental Chemistry Branch (ECB), ERDC, and the analytical assistance of Ms. Anne Weathersby is highly appreciated. Technical assistance provided by Dr. Terry Thonen, Dr. Curt Elmore, Mr. Jesse Kaldig, and Ms. Lisa Travelin, URS Greiner Woodward Clyde, Overland Park, Missouri, in aquifer material and groundwater sampling is highly acknowledged. Mr. Jeff Breckenridge, U.S. Army Corps of Engineers Center of Expertise, assisted in the collection of site data and will be involved in the field demonstration to ensure transition of the technology throughout the Army and Department of Defense (DoD). We gratefully acknowledge the assistance of Mr. Al Kam (CHAAP site manager) and Mr. Tom Graff (NOP site manager) that was necessary for the completion of the sampling effort.

This study was conducted in EL under the direct supervision of Dr. Patrick N. Deliman, Chief, Environmental Engineering Branch (EEB), and Dr. Richard E. Price, Chief, Environmental Processes and Engineering Division, and under the general supervision of Dr. Edwin A. Theriot, Director, EL.

At the time of publication of this report, Dr. James R. Houston was Director, and COL John W. Morris III, EN, was Commander and Executive Director of ERDC. 
This report should be cited as follows:

Wani, A. H., O’Neal, B. R., Davis, J. L., and Hansen, L. D. (2002).

"Treatability study for biologically active zone enhancement (BAZE) for in situ RDX degradation in groundwater," ERDC/EL TR-02-35, U.S. Army Engineer Research and Development Center, Vicksburg, MS.

The contents of this report are not to be used for advertising, publication, or promotional purposes. Citation of trade names does not constitute an official endorsement or approval of the use of such commercial products. 


\section{Introduction}

Explosive polynitroorganic contamination is present at many active and formerly used federal facilities. Nitroaromatics like 2,4,6-trinitrotoluene (TNT) and nitramines like hexahydro-1,3,5-trinitro-1,3,5-triazine (RDX) and octahydro1,3,5,7-tetranitro-tetrazocine (HMX) are the most common munition-derived pollutants encountered at military installations. Although related to nitrotoluene and nitric ester explosives by the presence of multiple nitro functional groups, nitramine explosives are unique in that the nitro groups are bounded to the central ring via nitrogen-nitrogen single bonds. These nitramines are xenobiotics. These explosive compounds have entered the environment from sites where they were manufactured, stored, disposed, or used in military training. Currently, the U.S. Army has 583 sites at 82 installations nationwide that are confirmed with explosives-contaminated groundwater. Additional 87 sites at 22 other installations are suspected of groundwater contamination with explosives and organics (Defense Environmental Network and Information Exchange (DENIX) 2001). Many more contaminated sites exist at Navy and Air Force facilities. Similar patterns of contamination are found throughout Europe and the former Soviet Union. Most of this contamination occurred during major conflicts when environmental health concerns were not an immediate priority. Recently, emphasis has increased on the health risks, both to humans and the environment, encountered from the potential exposures to these explosive compounds. Ordnance manufacturing facilities and other sites that have been heavily contaminated with energetic compounds are currently in the process of evaluation and remediation by the U.S. Army.

Munitions production wastewaters are most often treated by activated carbon adsorption of the organic pollutants followed by incineration of the spent carbon (VanderLoop et al. 1997). Currently, there is no generally accepted in situ process for the remediation of RDX in groundwater. Available remediation alternatives are limited to long-term groundwater pumping and ex situ treatment followed by discharge or reinjection of the treated water. The Best Available Technology (BAT) is sorption to granular activated carbon (GAC). Shortcomings of this approach include high initial capital cost for system emplacement, high costs associated with disposal of GAC, long-term operation and maintenance costs, and the anticipated long-term duration of proposed remediation activities (100 years at the Nebraska Ordnance Plant (NOP)) (Graff 2001).

The potential advantages of in situ biological treatment include low cost, ease of operation, and public acceptance. This study is the first phase of a 4-year field demonstration project, under the Environmental Security Technology Certification Program (ESTCP), for bioremediation of RDX-contaminated groundwater by 
Certification Program (ESTCP), for bioremediation of RDX-contaminated groundwater by enhancement of the biologically active zone. The purpose of this treatability study was to determine the suitability of either the NOP or Corhnusker Army Ammunition Plant (CHAAP) site for pilot-scale demonstration/validation of in situ remediation of RDX-contaminated groundwater. A series of column studies were conducted using site-specific aquifer material and groundwater to determine the feasibility of using the biologically active zone enhancement (BAZE) process to remediate groundwater. The study also delineated the reaction rate kinetics of RDX bioremediation and the effects of other parameters, such as carbon source (electron donors) on RDX bioremediation for subsequent use in pilot-scale field demonstration. 


\section{Literature Review}

TNT, RDX, and HMX are the most commonly encountered energetic contaminants found at military installations. These explosives have been manufactured on a massive scale in the past. Presently, soil and groundwater contamination by these explosives is a worldwide problem that started following intensive military activities in World War I (Akhavan 1998). In the United States, however, the contamination of soil and groundwater is attributed to World War II and the Korean conflict (Pennington 1999).

RDX falls under the nitramine class of explosive compounds in which nitro groups are attached to nitrogen components of a heterocyclic ring. The cyclic nitramines (RDX and HMX) are widely used in explosives because of their great explosive power, around one and a half to two times that of TNT, and rapid detonating velocity, approximately 1.3 times that of TNT. Because of their chemical similarities, most weapons grades of RDX contain 6 to 10 percent HMX as an impurity (Headquarters, Department of the Army (HQDOA) 1994).

Among these explosives, RDX is of particular environmental concern because it is generally resistant to microbial transformation in aerobic soils (McCormick, Cornell, and Kaplan 1981) and is readily leachable (Singh et al. 1998, Sheremata et al. 2001). Remediating soil and water contaminated with RDX is of vital importance because ingestion of RDX can adversely affect the central nervous system, gastro-intestinal tract, and kidneys. Common symptoms of RDX intoxication include nausea, vomiting, hyperirritability, headaches, and unconsciousness (Eitner 1989). RDX has also been associated with systemic poisoning usually affecting bone marrow and the liver (ATSDR 1996). Because of these effects shown in humans, the U.S. Environmental Protection Agency (USEPA) has established drinking water health advisories (HA) of $2 \mu \mathrm{g} \mathrm{L}^{-1}$ for exposure to RDX (USEPA 2000). RDX can be absorbed by plants from both soil and irrigation water. In radiolabeled RDX studies, Cataldo, Harvey, and Fellows (1990), Harvey et al. (1991), and Larson et al. (1999) have demonstrated that RDX was readily absorbed and migrated as intact compound and as metabolites throughout the plant tissue. The RDX uptake and distribution was more efficient than TNT. In support of these findings, subsequent studies by Fellows, Harvey, and Cataldo (1995) demonstrated that RDX was absorbed at about 2 to 16 times the rate of TNT in different plant species. Unlike TNT, the majority of the radiolabel remained as RDX within the plant, and the rate of conversion of RDX to metabolites in soil was insignificant. The evidence for bioaccumulation of explosive compounds in animals is incomplete and often contradictory (Major, Johnson, and Salice 2002). A study of the movement of RDX through trophic levels was conducted by Driver and Fellows (2000). Corn and alfalfa leaves 
grown on soil amended with radiolabeled RDX were added to commercial rabbit chow and fed to prairie voles (Microtus ochrogaster). About 7 and 11 percent of the plant-incorporated radiolabel was exhaled or excreted in the urine, respectively, and around 60 percent was excreted in the feces suggesting that the $\mathrm{RDX}$ in the plant tissue was bound to the less digestible (fiber) component of the diet. Retention of nearly 20 percent of the radiolabel in the tissues of the voles indicated that herbivorous animals that are capable of retaining and fermenting less digestible dietary components can bioaccumulate RDX and its metabolic intermediates. Relative bioaccumulation of RDX in herbivores or omnivores (including humans) will likely depend on their ability to facilitate fermentation of dietary fiber.

The fate and transport of RDX in the environment can be influenced by many factors including photolysis by sunlight, hydrolysis, and biologically mediated degradation. Under normal environmental conditions, photo degradation of RDX occurs rapidly. The half-life of RDX when exposed to direct sunlight was approximately $11 \mathrm{hr}$ (Sikka et al. 1980). The transformation products identified from the photolysis of RDX include nitrate, nitrite, formaldehyde, and nitrogen. Although significant hydrolysis of RDX has been shown to occur, it is unlikely that hydrolysis will be a significant factor in the fate of RDX under the conditions normally found in the environment (Sikka et al. 1980; Hoffsommer and Rosen 1973).

Biodegradation studies of RDX and/or HMX can be dated back to 1970s. Two decades ago, McCormick, Cornell, and Kaplan (1981) reported RDX biodegra-dation with municipal anaerobic sludge and proposed a pathway (Figure 1) based on sequential reduction of RDX to hexahydro-1-nitroso-3,5dinitro-1,3,5-triazine (MNX), hexahydro-1,3-dinitroso-5-nitro-1,3,5-triazine (DNX), and hexahydro-1,3,5-trinitroso-1,3,5-triazine (TNX). The proposed pathway suggests that the one or more nitro groups are reduced to the point where destabilization of the triazine ring occurs, and the ring is fragmented by hydrolytic cleavage. Fragments of the ring are further reduced resulting in a mixture of hydrazines, formaldehyde, and methanol (McCormick, Cornell, and Kaplan 1981, Walker and Kaplan 1992). Sikka et al. (1980) reported that in radio labeled studies, 80 percent of the $\left[{ }^{14} \mathrm{C}\right] \mathrm{RDX}$ added was evolved as ${ }^{14} \mathrm{CO}_{2}$ when 1 percent river sediment was added to the flasks. Evolution of ${ }^{14} \mathrm{CO}_{2}$ was preceded by a 10-day lag phase. Freedman and Sutherland (1998) studied RDX degradation under nitrate-reducing conditions and found that RDX biotransforms only after nitrate is completely consumed and nitroso derivatives are found as metabolites.

The anaerobic degradation pathway currently accepted is problematic because of the existence of the proposed nitroso intermediates, some of which are genotoxic carcinogens (Pitot and Dragan 1996). Furthermore, DNX is a proven human carcinogen in comparison to the parent compound - RDX - whose carcinogenicity is currently under review (Major, Johnson, and Salice 2002). Accumulation of these transformation products would require more stringent remedial action than the parent compound. Therefore, a biologically mediated RDX degradation process should result in further breakdown of these nitroso intermediates to reach an acceptable environmental end point. Hawari et al. 


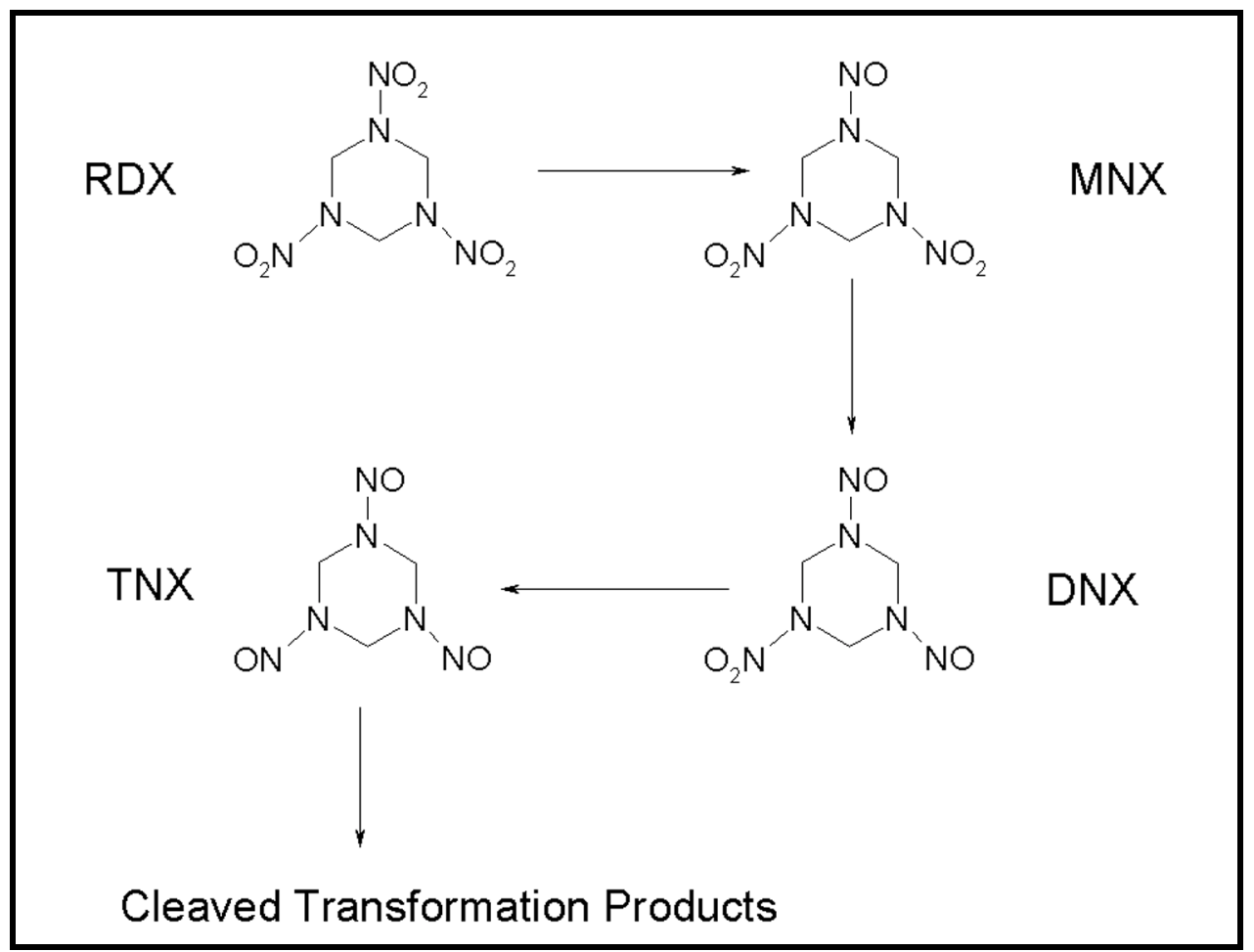

Figure 1. Anaerobic pathway

(2000) have claimed evidence of formation of two-ring cleavage metabolites (methylenedinitramine and bis-hydroxymethyl-nitramine) during the treatment of RDX with domestic anaerobic sludge. Both of these metabolites are reported to decompose in water to produce nitramine and formaldehyde, which in turn biotransform to nitrous oxide and carbon dioxide. These findings were confirmed recently by Halasz et al. (2002); however, it is not certain whether methylenedinitramine was an initial enzymatic hydrolysis product or simply formed via the spontaneous hydrolysis of an unknown initial RDX enzymatic product.

Researchers reported that the results from anaerobic studies suggest that degradation of RDX was a cometabolic process, and a source of organic carbon had to be present to achieve RDX degradation. The observation that RDX degradation occurred only in the presence of sugars implies that a large amount of reducing power is required, possibly in the form of NADH and NADPH (Binks, Nicklin, and Bruce 1995). However, it is often difficult to determine which terminal electron acceptor was in use during the transformation (Freedman and Sutherland 1998).

Although RDX is generally believed to be persistent under aerobic conditions (McCormick, Cornell, and Kaplan 1981; Spanggord et al. 1980b), recent experimental evidence has shown some potential of aerobic mineralization of RDX. Sheremata and Hawari (2000) reported that white rot fungus Phanerochaete chrysosporium used RDX as the main nitrogen source with MNX and methanol as trace metabolites and produced $\mathrm{N}_{2} \mathrm{O}$ and $\mathrm{CO}_{2}$ as mineralization products. About 52.9 percent of RDX was mineralized as $\mathrm{CO}_{2}, 10.7$ percent 
taken up as biomass, and 28.3 percent remained in aqueous phase as unidentified metabolites. Another study by Fernando and Aust (1991) with P. chrysosporium found that 67 percent of $\mathrm{RDX}$ was mineralized to $\mathrm{CO}_{2}$ and 20.2 percent was recovered as water-soluble metabolites. Coleman, Nelson, and Duxbury (1998) identified aerobic gram-positive bacteria capable of using RDX as the sole nitrogen source. The strain, DN22, used nitrite released from RDX as a growth substrate and the presence of ammonium reduced the amount of RDX degradation because of preferential use of ammonium as nitrogen source.

The fact that many biological systems - anaerobic as well as aerobic - are capable of catalyzing the reduction of nitro substituents is the result of the chemical properties of the nitro group. Considerations about transformation of nitroaromatic energetic compounds in the soil and aquifer must include anaerobic reactions, because soil is a heterogeneous medium with different oxygen partial pressures (Preub and Rieger 1995). Although many researchers have established that RDX can be degraded through biological processes, successful application of these techniques to in situ treatment of contaminated soils and waters has yet to be proven in the field. The purpose of this study was to determine the suitability of in situ biological degradation of RDX for the remediation of contaminated groundwater. 


\section{Site Screening and Selection}

\section{Site Screening}

The selection of a site to demonstrate the BAZE process for the remediation of RDX contaminated groundwater is of utmost importance. Because of the large number of contaminated Department of Defense (DoD) sites, an objective screening was performed to reduce the number to manageable levels. The screening process was performed in collaboration with the U.S. Army Corps of Engineers (USACE), Center of Expertise (CX), Omaha, NE, using an objective screening system (Hansen and Davis 2001) described below. This screening process was based on four general profile areas: project management support, explosive contamination level, aquifer depth, and other factors like secondary contamination. A list of screening (go/no-go) criteria was developed and is summarized in Table 1.

\begin{tabular}{|c|c|c|}
\hline \multicolumn{3}{|c|}{$\begin{array}{l}\text { Table } 1 \\
\text { Criteria for Site Screening }\end{array}$} \\
\hline Screening Criteria & Acceptable & Unacceptable \\
\hline 1) PM Support & Yes & No \\
\hline 2) RDX Contamination & $>20 \mu \mathrm{g} \mathrm{L}^{-1}$ & $<20 \mu \mathrm{g} \mathrm{L}^{-1}$ \\
\hline 3) Contamination Depth & $<30.7 \mathrm{~m}(100 \mathrm{ft})$ & $>30.7 \mathrm{~m}(100 \mathrm{ft})$ \\
\hline 4) Other important factors & & \\
\hline
\end{tabular}

These criteria were chosen to eliminate those sites that have a low likelihood of success during the field demonstration/validation phase of the project from further consideration.

a. Site project manager (PM) support is an indication of the nontechnical issues which may impact a project. Issues such as project schedule, regulator, customer, and stakeholder concerns all may determine the level of support available from the PM. If one or more of these issues is negatively impacted, it will be difficult for the PM to support the treatability study and demonstration/validation phase of the project. Finally, these issues could lead to demonstration/validation failure 
unfairly attributed to the technology being demonstrated rather than the nontechnical issues that could cause failure.

$b$. The level of contamination at the site is an important factor when deciding the site for validation. A site should have groundwater contamination at sufficient levels so that statistically significant contaminant reductions can be shown during the demonstration/validation phase. If contaminant levels are low, it will be difficult to distinguish concentration reductions from background variability. Concentrations of $20 \mu \mathrm{g} \mathrm{L}^{-1}$ and greater will allow for a reduction of 90 percent or greater to reach USEPA's HA level of $2 \mu \mathrm{g} \mathrm{L}^{-1}$ (USEPA 2000).

c. The depth to the bottom of the contaminant zone is a significant factor in the determination of costs involved in the demonstration project. The desired method of collecting cores and placing injection and monitoring wells is direct-push. This method can be used up to depths of $30.5 \mathrm{~m}$ $(100 \mathrm{ft})$, depending on the type of soil. Selecting a site with greater depths may require a more rigorous drilling method and, consequently, may increase the costs of the pilot-scale demonstration.

d. Other factors include all available data that will be evaluated to determine if there are any other factors that will be detrimental to the BAZE process. Examples of possible factors that may eliminate a site from consideration are heavy metal toxicity, extreme $\mathrm{pH}$ (acidic and alkaline), and other toxic materials.

Data from the 10 sites selected to undergo the initial screening process were collected with the assistance of Mr. Jeff Breckinridge at the USACE's CX to undergo the initial screening process. A detailed description of these sites is given in Appendix A, Table A1.

The data from each site were applied to the screening protocol described above and the results of initial screening are summarized in Table 2.

Sites shown in boldface successfully passed the screening process and further evaluation was performed for the selection of primary and secondary demonstration sites. Massachusetts Military Reservation (MMR) and Umatilla Army Depot (UAD) were rejected because the depth to contamination exceeded the screening criterion. Iowa Army Ammunition Plant (IAAP) was rejected because the groundwater was not well characterized. The Tooele site was rejected because of low contamination and depth to contamination. Picatinny Arsenal was rejected because of lack of data.

\section{Site Selection}

The five sites selected for further evaluation (Table 2) were contacted for additional information on four major selection criteria: contamination, hydrogeology, geochemical profile, and infrastructure. Details concerning the individual selection criterion are shown in Table 3. 


\begin{tabular}{|c|c|c|c|c|c|}
\hline \multicolumn{6}{|c|}{$\begin{array}{l}\text { Table } 2 \\
\text { Results of Site Screening }\end{array}$} \\
\hline Sites & $\begin{array}{l}\text { PM } \\
\text { Support } \\
\text { Yes/No }\end{array}$ & $\begin{array}{l}\text { RDX } \\
\text { Contamination } \\
>20 \mu \mathrm{g} \mathrm{L}^{-1} \text {, } \\
<20 \mu \mathrm{g} \mathrm{L}^{-1}\end{array}$ & $\begin{array}{l}\text { Contamination } \\
\text { Depth } \\
<100 \mathrm{ft} \text {; } \\
>100 \mathrm{ft}\end{array}$ & $\begin{array}{l}\text { Other } \\
\text { Important } \\
\text { Factors } \\
\text { Yes/No } \\
\end{array}$ & Contact Information \\
\hline NOP, NE & Yes & Good & Good & Yes & $\begin{array}{l}\text { Tom Graf, NWK } \\
816-983-3351\end{array}$ \\
\hline $\begin{array}{l}\text { CHAAP, } \\
\text { NE }\end{array}$ & Yes & Good & Good & Yes & \begin{tabular}{|l|} 
Alvin Kam, NWO \\
402-221-7758
\end{tabular} \\
\hline PAD, CO & Yes & Good & Good & Yes & \begin{tabular}{|l|} 
Todd Wilson, NWO \\
$402-221-7750$ \\
\end{tabular} \\
\hline $\begin{array}{l}\text { LAAP, } \\
\text { LA }\end{array}$ & Yes & Good & Good & Yes & \begin{tabular}{|l} 
Doyle Williams, \\
Environmental Officer \\
318-459-5108
\end{tabular} \\
\hline FM, MD & Yes & Good & Good & Yes & $\begin{array}{l}\text { Russ Marsh, NAB } \\
410-962-2227\end{array}$ \\
\hline $\begin{array}{l}\text { MMR, } \\
\text { MA }\end{array}$ & Yes & Good & Marginal & Yes & \begin{tabular}{|l|} 
Phil Durgin, NAE \\
$978-318-8507$ \\
\end{tabular} \\
\hline $\begin{array}{l}\text { UAD, } \\
\text { OR }\end{array}$ & Yes & Good & Marginal & Yes & \begin{tabular}{|l|} 
Kira Lynch, NWS \\
206-764-6918 \\
\end{tabular} \\
\hline IAAP, IA & Yes & Good & Good & No & \begin{tabular}{|l|} 
Ted Streckfuss, NWO \\
402-221-3826 \\
\end{tabular} \\
\hline $\begin{array}{l}\text { Tooele, } \\
\text { UT }\end{array}$ & Yes & Low & No & Yes & $\begin{array}{l}\text { Brad Call, SAS } \\
916-557-6649\end{array}$ \\
\hline $\begin{array}{l}\text { Picatinny } \\
\text { Arsenal, } \\
\text { NJ }\end{array}$ & No & Not available & Not available & $\begin{array}{l}\text { Not } \\
\text { available }\end{array}$ & $\begin{array}{l}\text { Russ Marsh, NAB } \\
410-962-2227\end{array}$ \\
\hline
\end{tabular}

\begin{tabular}{|c|c|c|c|c|}
\hline \multicolumn{5}{|l|}{$\begin{array}{l}\text { Table } 3 \\
\text { Selection Criteria }\end{array}$} \\
\hline \multirow[b]{2}{*}{ Selection Criteria } & -1 & $\overline{0}$ & 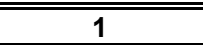 & \\
\hline & Negative & Neutral & Positive & Weighting \\
\hline 1) Contamination & & & & 40 \\
\hline a) RDX & & $<200 \mu \mathrm{g} \mathrm{L}^{-1}$ & $>200 \mu \mathrm{g} \mathrm{L}^{-1}$ & 40 \\
\hline 2) Hydrogeologic & & & & 15 \\
\hline a) Groundwater velocity & $<0.1 \mathrm{ft} \mathrm{d}^{-1}$ & & $>1 \mathrm{ft} \mathrm{d}^{-1}$ & 6 \\
\hline b) Hydraulic Conductivity & $<10^{-5} \mathrm{~cm} \mathrm{sec}^{-1}$ & & $>10^{-3} \mathrm{~cm} \mathrm{sec}^{-1}$ & 9 \\
\hline 3) Geochemical & & & & 30 \\
\hline a) Dissolved Oxygen & $>3.0 \mathrm{mg} \mathrm{L}^{-1}$ & & $<0.5 \mathrm{mg} \mathrm{L}^{-1}$ & 5 \\
\hline b) Nitrate & $>5 \mathrm{mg} \mathrm{L}^{-1}$ & & $<1 \mathrm{mg} \mathrm{L}^{-1}$ & 3 \\
\hline c) Sulfate & & $\begin{array}{l}<20 \mathrm{mg} \mathrm{L}^{-1} \text { or } \\
>100 \mathrm{mg} \mathrm{L}^{-1}\end{array}$ & $\begin{array}{c}>20 \mathrm{mg} \mathrm{L}^{-1} \text { and } \\
<100 \mathrm{mg} \mathrm{L}^{-1}\end{array}$ & 10 \\
\hline d) Dissolved Organic Carbon & $<1 \mathrm{mg} \mathrm{L}^{-1}$ & & $>20 \mathrm{mg} \mathrm{L}^{-1}$ & 4 \\
\hline e) $\mathrm{pH}$ & $<5$ or $>9$ & & $6.5-7.5$ & 4 \\
\hline f) Bicarbonate Alkalinity & $<1 \mathrm{~g} \mathrm{~L}^{-1}$ & & $>5 \mathrm{~g} \mathrm{~L}^{-1}$ & 4 \\
\hline 4) Infrastructure & & & & 15 \\
\hline a) Leverage Funding & & No & Yes & 10 \\
\hline b) Electricity & Not Present & & Present & 1 \\
\hline c) Water & Not Present & & Present & 1 \\
\hline d) Monitor Wells & Not Present & & Present & 3 \\
\hline Total & & & & 100 \\
\hline
\end{tabular}


a. Contamination profile. The primary consideration in selecting a site for the demonstration/validation was the type and extent of site contamination. Sufficient level of energetics contamination is necessary to evaluate the presence, relative concentration, and distribution of RDX reductive transformation products when assessing the sites for the potential of a successful demonstration of the BAZE process. A complete contaminant profile included a description and the distribution of contaminant. Contaminant distribution analysis included a depiction of the contaminant plume and concentration contours that will aid in the placement of injection and monitoring wells should the site be selected for the demonstration/validation.

b. Hydrogeology. The success of the BAZE process relies on the distribution of amendments throughout the subsurface. The uniform distribution of amendments is easily achievable in a sandy aquifer with a relatively high groundwater velocity. The hydraulic conductivity criterion is indicative of a sandy $\left(10^{-3} \mathrm{~cm} \mathrm{sec}^{-1}\right)$ or a clayey $\left(10^{-5} \mathrm{~cm} \mathrm{sec}^{-1}\right)$ aquifer. High groundwater velocity will facilitate a more rapid distribution of amendments following injection.

c. Geochemical profile. Geochemistry influences the potential for stimulating and maintaining the conditions necessary for the reductive biotransformation of RDX. RDX degrading microorganisms require an anaerobic environment. The order of electron acceptor utilization is oxygen, nitrate, RDX, and sulfate. Lower concentrations of oxygen and nitrate will allow for more rapid removal of RDX and less use of amendments. Previous research at U.S. Army Engineer Research and Development Center (ERDC), Vicksburg, MS (Davis, Hansen, and O'Neal 2001), has shown that a higher presence of sulfate will induce more reduced conditions, thereby decreasing the induction time and accelerating the removal of RDX. The presence of dissolved organic carbon in the subsurface will reduce the necessary amount of amendments to be injected in the BAZE process. Neutral $\mathrm{pH}$ and higher alkalinity are needed to ensure a stable environment for subsurface microorganisms.

d. Infrastructure. The presence of infrastructure at the site under consideration will reduce the total cost of the implementation of the BAZE process. The presence of electrical power will eliminate the need to purchase portable generators to operate pumps and data-logging equipment. The presence of a potable water source will provide a ready source for mixing amendments. Leveraged funding may come in two sorts (funds and effort in kind). Effort in kind may include onsite personnel to operate equipment and/or provide sampling support.

The additional information obtained from the five screened sites on these selection parameters is tabulated in Appendix A, Table A2. Table 4 is a summary of the application of the selection process. The result of this evaluation indicated that the NOP site in Nebraska has the greatest likelihood for a successful demonstration of the BAZE process and was selected as the primary site. The secondary site, based on this evaluation, was determined to be the 
CHAAP site in Nebraska. The principal concern of selecting CHAAP as the secondary site is its geographical proximity about $240 \mathrm{~km}$ (150 miles) from NOP site (Figure 2).

\begin{tabular}{|c|c|c|c|c|c|}
\hline \multicolumn{6}{|c|}{$\begin{array}{l}\text { Table } 4 \\
\text { Summary of Selection Process }\end{array}$} \\
\hline & NOP, NE & CHAAP, NE & PAD, CO & LAAP, LA & FM, MD \\
\hline \multicolumn{6}{|l|}{ 1) Contamination } \\
\hline $\mathrm{RDX}, \mu \mathrm{g} \mathrm{L}^{-1}$ & $40(220)$ & $40(35-2000)$ & $0(23-55)$ & $40(20-1700)$ & $0(4-120)$ \\
\hline \multicolumn{6}{|l|}{ 2) Hydrogeologic } \\
\hline $\begin{array}{r}\text { Groundwater Velocity, } \\
\mathrm{ft} \mathrm{d}^{-1}\end{array}$ & $6(2)$ & 0 (ND) & $6(6.5)$ & $-6(0.001)$ & $-6(0.08)$ \\
\hline $\begin{array}{r}\text { Hydraulic Conductivity, } \\
\mathrm{cm} \mathrm{sec}^{-1}\end{array}$ & $9\left(1.7 \times 10^{-2}\right)$ & 0 (ND) & $9\left(9.8 \times 10^{-3}\right)$ & $\mathbf{0}(\mathrm{ND})$ & $9\left(1.8 \times 10^{-3}\right)$ \\
\hline \multicolumn{6}{|l|}{ 3) Geochemical } \\
\hline Dissolved Oxygen, $\mathrm{mg} \mathrm{L}^{-1}$ & $5(0-10)$ & 0 (ND) & $-5(12-20)$ & $5(0.3)$ & $-5(4-7)$ \\
\hline Nitrate, $\mathrm{mg} \mathrm{L}^{-1}$ & $-3(6-8)$ & $0(\mathrm{ND})$ & $-3(18-80)$ & $-3(14.6)$ & 0 (ND) \\
\hline Sulfate, $\mathrm{mg} \mathrm{L}^{-1}$ & $10(39-110)$ & 0 (ND) & $0(77-480)$ & $10(76.1)$ & 0 (ND) \\
\hline $\begin{array}{r}\text { Dissolved Organic } \\
\text { Carbon, } \mathrm{mg} \mathrm{L}^{-1} \\
\end{array}$ & $\mathbf{0}(1.5-3)$ & 0 (ND) & 0 (ND) & 4 (ND) & $\mathbf{0}(\mathrm{ND})$ \\
\hline $\mathrm{pH}$ & $4(6.6-7.3)$ & $\mathbf{0}(\mathrm{ND})$ & $4(7-7.6)$ & $\mathbf{0}(5-8)$ & $-4(4.3-6)$ \\
\hline Alkalinity, $\mathrm{mg} \mathrm{L}^{-1}$ & $-4(170-190)$ & $0(\mathrm{ND})$ & $-4(160-265)$ & 0 (ND) & $-4(9.4)$ \\
\hline \multicolumn{6}{|l|}{ 4) Infrastructure } \\
\hline Leveraged Funding & 10 & 10 & 10 & 0 & 0 \\
\hline Electricity & 0 & 0 & 0 & 0 & 0 \\
\hline Water & 0 & 0 & 0 & 0 & 0 \\
\hline Monitor Wells & 3 & 3 & 3 & 3 & 3 \\
\hline Score & 80 & 53 & 20 & 49 & -7 \\
\hline
\end{tabular}

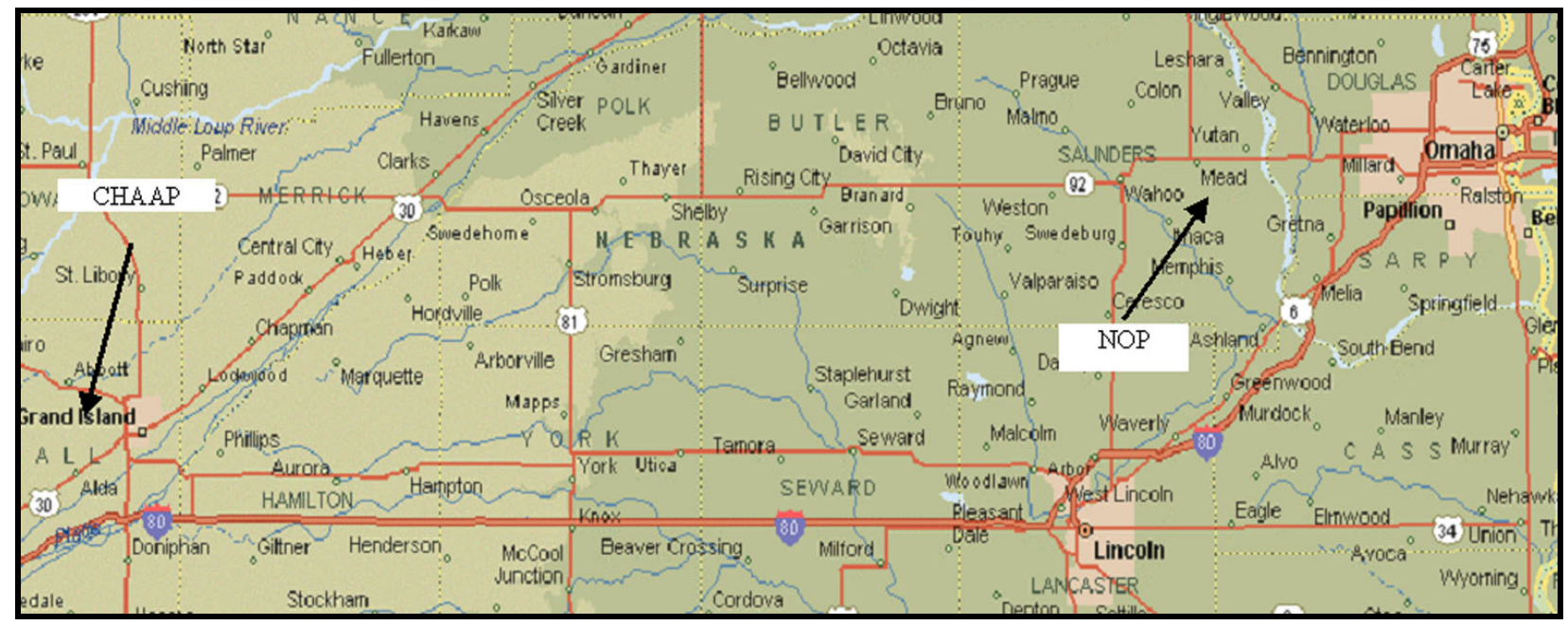

Figure 2. Location of selected sites 


\section{Selected Sites Description}

\section{Nebraska Ordnance Plant (NOP)}

The former NOP is located about one-half mile south of Mead, NE, which is $48 \mathrm{~km}$ (30 miles) west of Omaha and $56 \mathrm{~km}$ (35 miles) northeast of Lincoln, NE. NOP covers $69.9 \mathrm{sq} \mathrm{km} \mathrm{(17,258} \mathrm{acres)} \mathrm{in} \mathrm{Saunders} \mathrm{County.} \mathrm{Currently,} \mathrm{the} \mathrm{land}$ is owned by the University of Nebraska, Agricultural Research and Development Center (ARDC), U.S. Army National Guard and Reserves, U.S. Department of Commerce, and private interests. The NOP was a load, assemble, and pack facility, which produced bombs, boosters, and shells. Most of the raw materials used to manufacture the weapons at the former NOP were fabricated at other locations and shipped to the former NOP for assembly; however, ammonium nitrate was produced onsite for the first months of operation in 1943. The plant was operated intermittently for about 20 years until 1962. During World War II, the production facilities were operated by Nebraska Defense Corporation. Production was terminated for the interim period 1945 through 1949. In 1950, the former NOP was reactivated to produce an assortment of weapons for use in the Korean conflict. NOP was placed on standby status in 1956 and declared excess to Army needs in 1959.

Bedrock beneath the northeastern portion of site (in Todd Valley) consists of Cretaceous shales and sandstones of the Omandi Formation. The Omandi Formation is underlain by Pennsylvanian shales and limestones. The Omandi Formation has been divided into an upper shale and lower sandstone lithofacies at the site. The sandstone lithofacies of the Omandi Formation are fine to medium grained with some gravel at the base. The sandstone varies in thickness from 6 to $32 \mathrm{~m} \mathrm{(20} \mathrm{to} 105 \mathrm{ft}$ ) below ground surface (bgs). The shale lithofacies is a clayey nonclacareous shale with some interbedded thin silt and sand. The maximum thickness of shale is about $15.9 \mathrm{~m}(52 \mathrm{ft})$. The southeast portion of the site (in Platte River Valley) consists of sand and sandy gravel layer of 11.9 to $14.9 \mathrm{~m}$ (39 to $49 \mathrm{ft})$ thickness. Overbank silts and clays, 3 to $5.2 \mathrm{~m}(10$ to $17 \mathrm{ft})$ thick, overlie the Platte River alluvial sand. The transmissivity of the Platte River alluvial aquifer, estimated through slug testing, is $18.6 \times 10^{4} \mathrm{~L} \mathrm{~d}^{-1} \mathrm{~m}^{-1}(1.5$ $\left.\times 10^{4} \mathrm{gal} \mathrm{d}^{-1} \mathrm{ft}^{-1}\right)$. The hydraulic conductivity of Todd Valley fine sand unit is estimated at $0.017 \mathrm{~cm} \mathrm{sec}^{-1}\left(0.034 \mathrm{ft} \mathrm{min}^{-1}\right)$, and the Todd Valley sand and gravel unit is $0.04 \mathrm{~cm} \mathrm{sec}^{-1}\left(0.08 \mathrm{ft} \mathrm{min}^{-1}\right)$. The hydraulic conductivity of Omandi sandstone aquifer is estimated at $0.02 \mathrm{~cm} \mathrm{sec}^{-1}\left(0.044 \mathrm{ft} \mathrm{min}^{-1}\right)$ (URSGWC 2000).

The results of 1991-92 evaluation study by the USACE indicated that explosive contamination in soil is mostly limited to soils in and under drainage ditches and sumps in the load lines and the Bomb Booster area. It is believed that this contamination originated from the discharge of water used to wash away explosive dust and residue which resulted from the ordnance load, assemble, and pack process. RDX, TNT, and 1,3,5-trinitrobenzene (TNB) were the explosive contaminants most often detected. RDX, TNT and trichloroethane (TCE) were identified in the groundwater samples. 


\section{Cornhusker Army Ammunition Plant (CHAAP)}

CHAAP is located on a 48.3-sq km (11,936-acre) tract approximately $3.2 \mathrm{~km}$ (2 miles) west of Grand Island, NE. CHAAP was constructed and became fully operational in 1942 as a U.S. Government-owned, contractor-operated facility for the production of artillery shells, mines, bombs, and rockets for World War II, and the Korean and Vietnam conflicts. Various types of bombs, artillery shells, boosters, rockets, and supplementary charges were produced at CHAAP using primarily TNT, and a mixture of TNT, RDX, and HMX. The plant was operated intermittently for 30 years with the most recent operations ending in 1973.

In general, the geological units underlying the CHAAP area include (a) a 0to $1.5-\mathrm{m}(0-$ to $5-\mathrm{ft})$ layer of alluvial silty clay and topsoil near the surface, (b) 15.2 - to $18.3-\mathrm{m} \mathrm{(50-} \mathrm{to} 60-\mathrm{ft})$-thick alluvial sands and gravels of the Grand Island Formation, (c) 1.5- to 4.5-m (5- to 15-ft)-thick low-permeable layer of alluvial silty clay of the Fullerton Formation, and (d) a lower layer of alluvial sands and gravels of the Holdrege Formation up to a 61-m (200-ft) thickness. Shallow groundwater underlying the facility occurs as an unconfined aquifer within the alluvial sands and gravels of the Grand Island Formation. The water table surface is generally less than $3 \mathrm{~m}(10 \mathrm{ft}) \mathrm{bgs}$. Total thickness of the water table aquifer ranges from about 15.2 to $18.3 \mathrm{~m}$ (50 to $60 \mathrm{ft})$. Hydraulic conductivity values ranges up to $0.24 \mathrm{~cm} \mathrm{sec}^{-1}\left(670 \mathrm{ft} \mathrm{d}^{-1}\right)$ (URSGWC 1999).

Explosive wastes and residues associated with munitions loading, assembly, and packing materials have resulted in a groundwater contamination plume that originates at waste leach pits and cesspools of the CHAAP loading lines and extends into the city of Grand Island. The explosive compounds have migrated northeast with the predominant direction of groundwater flow. Relatively nonsorbing compounds, RDX and HMX, have migrated the greatest distance as compared to highly sorbing TNT. During 1987-88, the U.S. Army conducted an incineration project designed to excavate and treat soils beneath leach pits and cesspools of CHAAP load lines. The project reduced the sources of contamination, however at many locations remediation action levels could not be achieved before groundwater was encountered (USRGWC 1999). 


\section{Sampling}

Samples of aquifer material and groundwater were collected from the two selected sites (NOP and CHAAP in Nebraska) and transported to the ERDC, Environmental Laboratory (EL), Vicksburg, MS, for analysis and evaluation. Three potential areas at the NOP site were evaluated by onsite groundwater screening to determine the area best suited for BAZE process. Four groundwater screening samples from a depth of $13.7 \mathrm{~m}(45 \mathrm{ft})$ bgs were collected from each area using direct push rig. These groundwater samples were analyzed onsite using DETECH ${ }^{\mathrm{TM}}$ RDX immunoassay field test kits (URSGWC 2001). For quality assurance/quality control (QA/QC) split samples were shipped to the ERDC laboratory for RDX analysis. On the basis of these screening tests, Area 1 was selected for feasibility study and field demonstration (Figure 3). The field screening was not needed at the CHAAP site because of the availability of historical groundwater monitoring data from two monitoring wells (G0022 and G0075) in the selected area (Figure 4). Sampling was performed by Mr. Jesse Kading, URS Group Inc., Kansas.

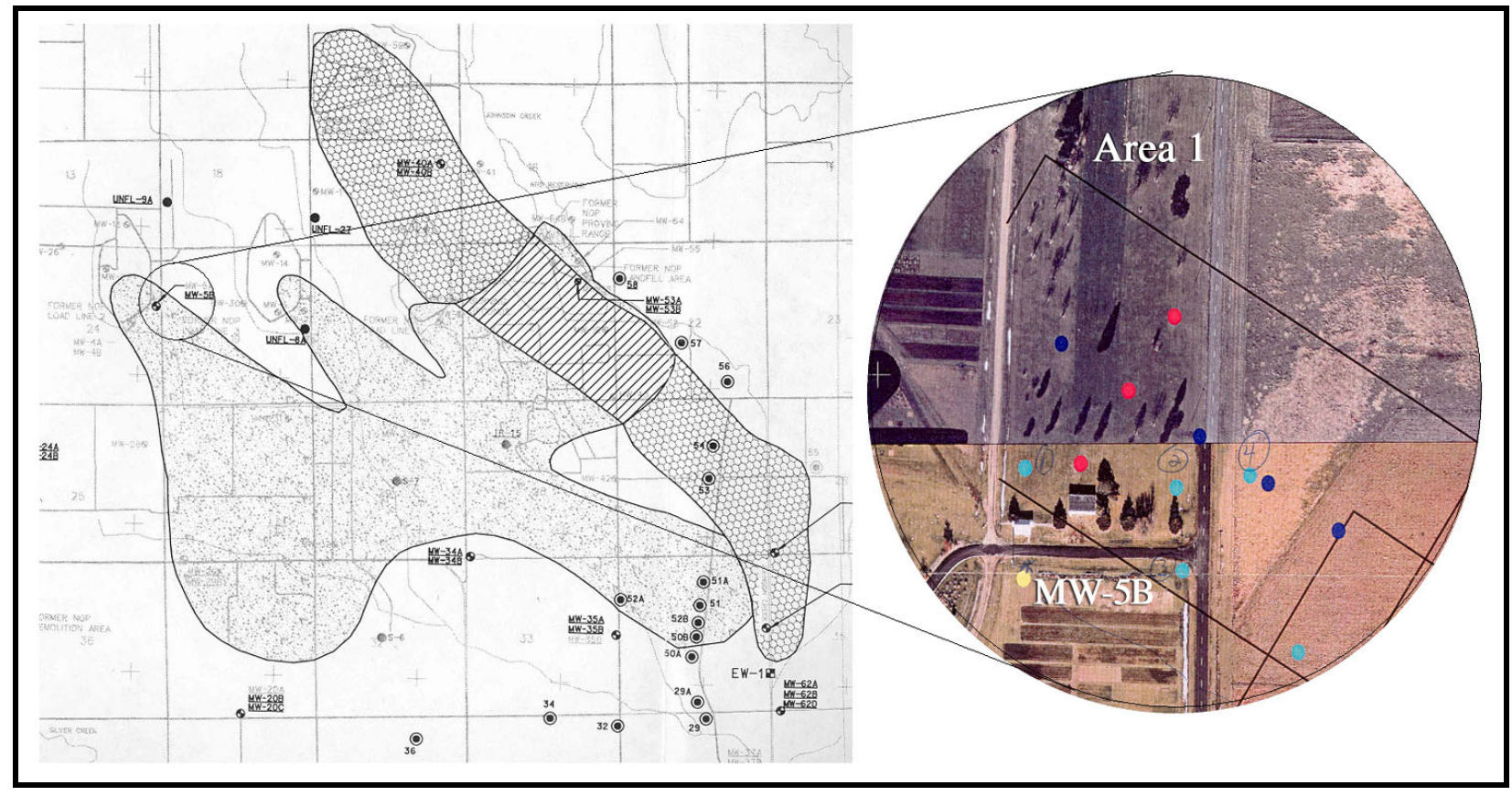

Figure 3. Sampling location at NOP site 


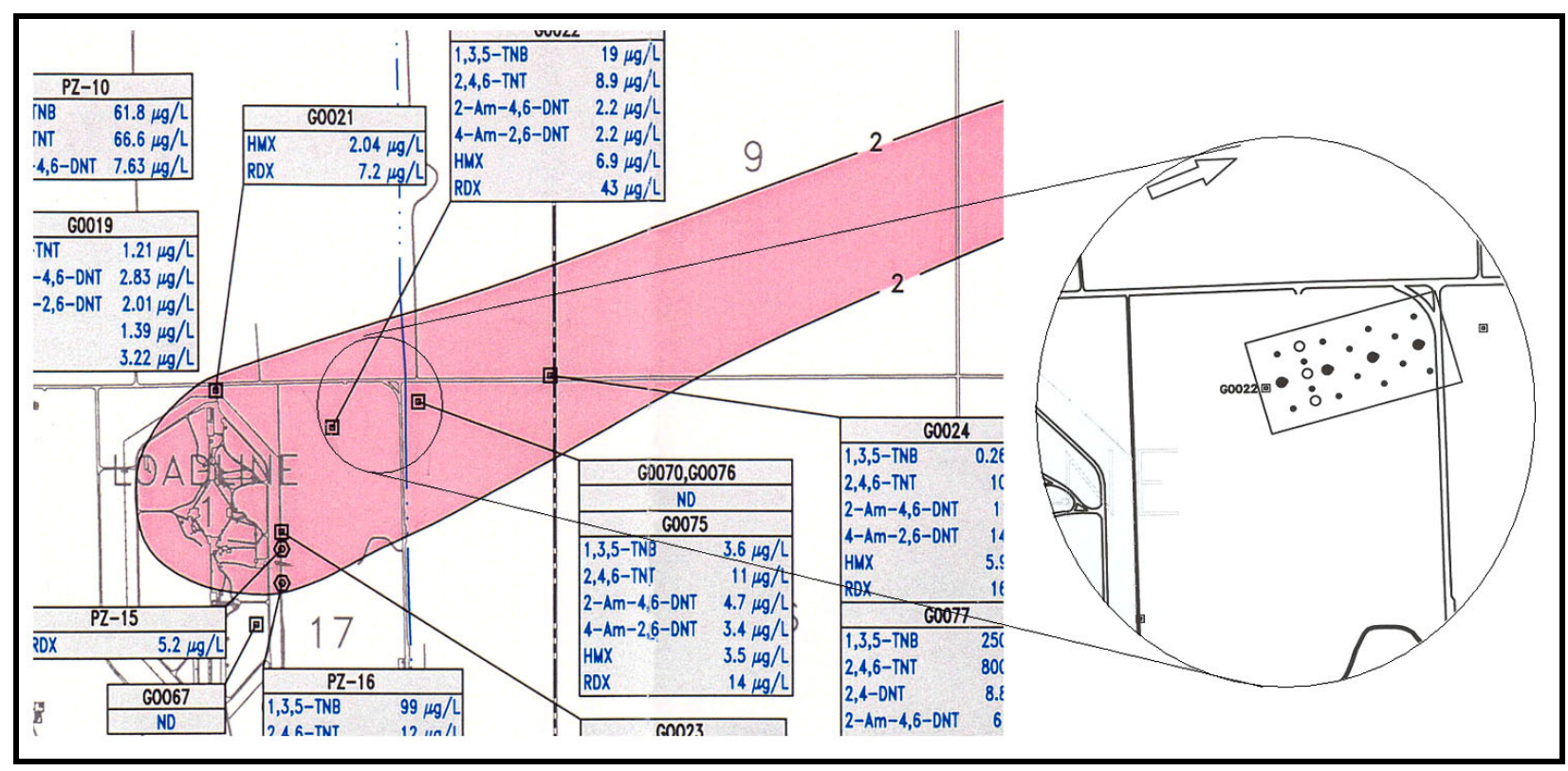

Figure 4. Sampling location at CHAAP site

\section{Aquifer Material}

Aquifer material at the NOP site was collected from the Area 1 near monitoring well MW-5B from a depth of 11 to $12 \mathrm{~m}$ ( 36 to $40 \mathrm{ft}$ ) bgs. At CHAAP site, the soil material was collected near monitoring well G0022 from a depth of 9 to $10 \mathrm{~m}$ ( 30 to $34 \mathrm{ft}$ ) bgs. Soil columns were collected by the direct-push method using a track-mounted mobile sampling device (Figure 5). A 5-cm (2-in.)-diameter acetate liner was inserted into a Geoprobe ${ }^{\circledR}$ Macro-Core ${ }^{\circledR}$ sampler and pushed to the desired depth. The Macro-Core ${ }^{\circledR}$ sampler had a 1.2-m (4-ft) stroke, thus allowing for a 1.2-m (4-ft) soil column. Once a 1.2-m (4-ft) soil column was collected, both ends of the liner were sealed with plastic caps and taped. The soil columns were thoroughly sealed at both ends to prevent loss of water from the aquifer material during storage and shipping (Figure 6). From each site, 18 to 20 cores of aquifer material were collected and shipped to ERDC, EL, via a refrigerated truck.

\section{Groundwater}

Groundwater samples at NOP were collected from well MW-5B and from well G0022 at CHAAP. About 750 L (four 55-gal drums) of explosives contaminated groundwater was collected from each site and transported to ERDC, EL, along with the aquifer material by a refrigerated truck. At NOP and CHAAP, monitoring wells (MW-5 and G0022, respectively) were sampled by a submersible pump. Once the three well volumes were removed, groundwater was collected in 210-L (55-gal) drums (Figure 7). 


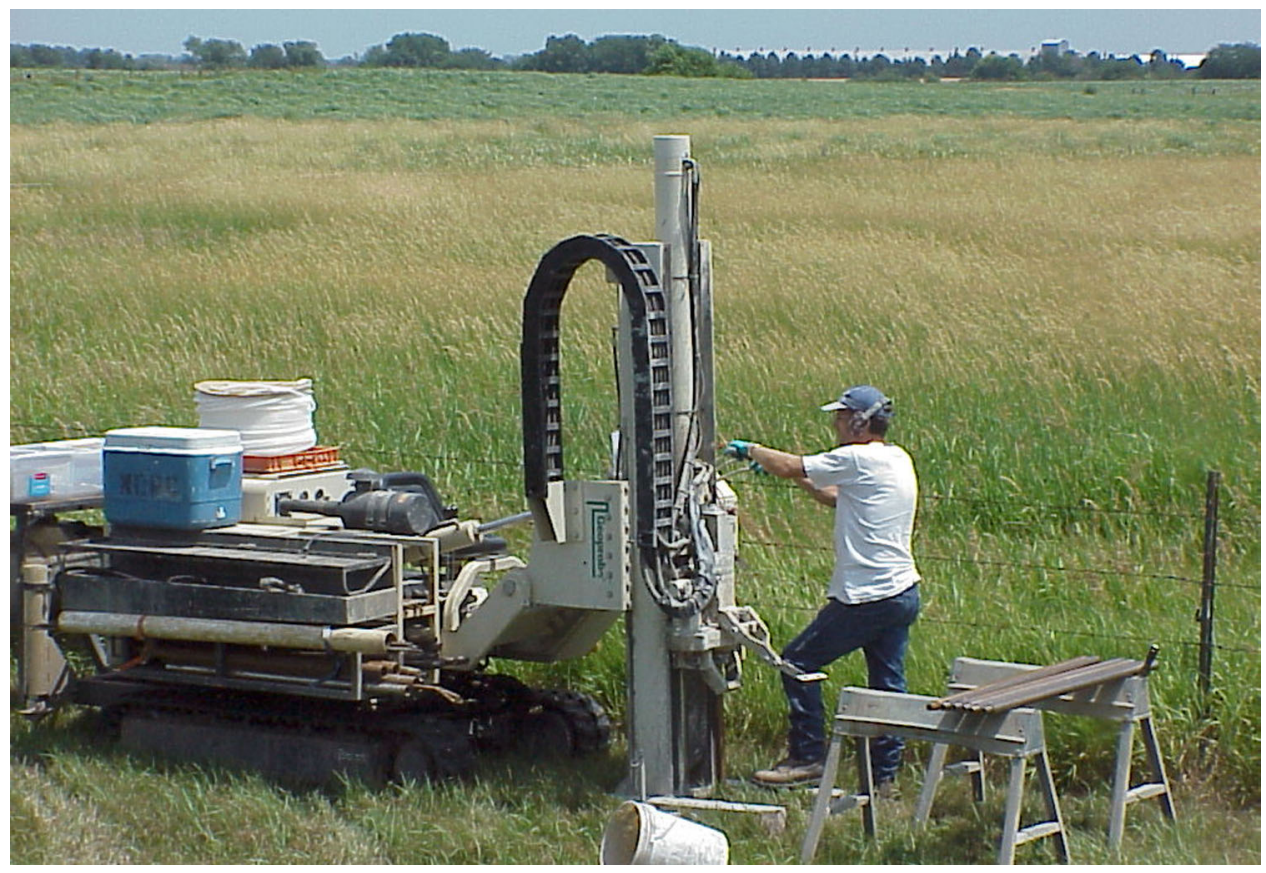

Figure 5. Direct-push sampling device

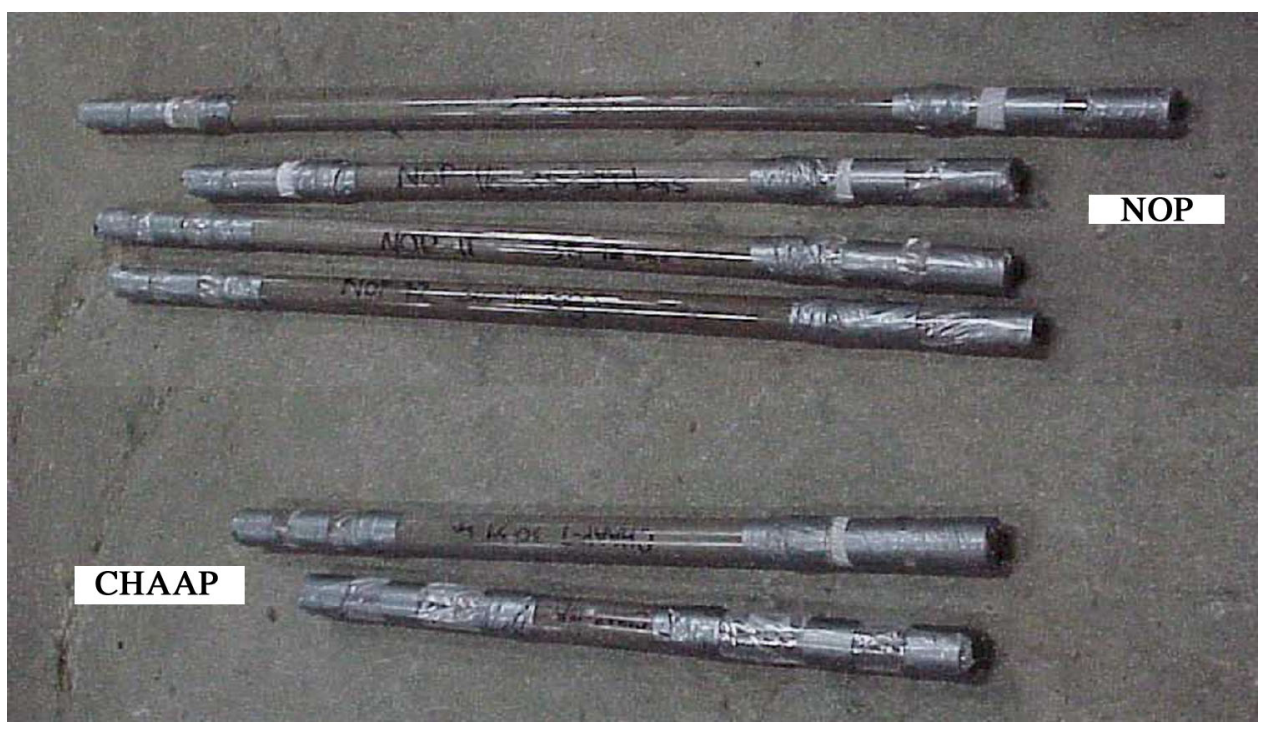

Figure 6. Aquifer material in acetate liners 


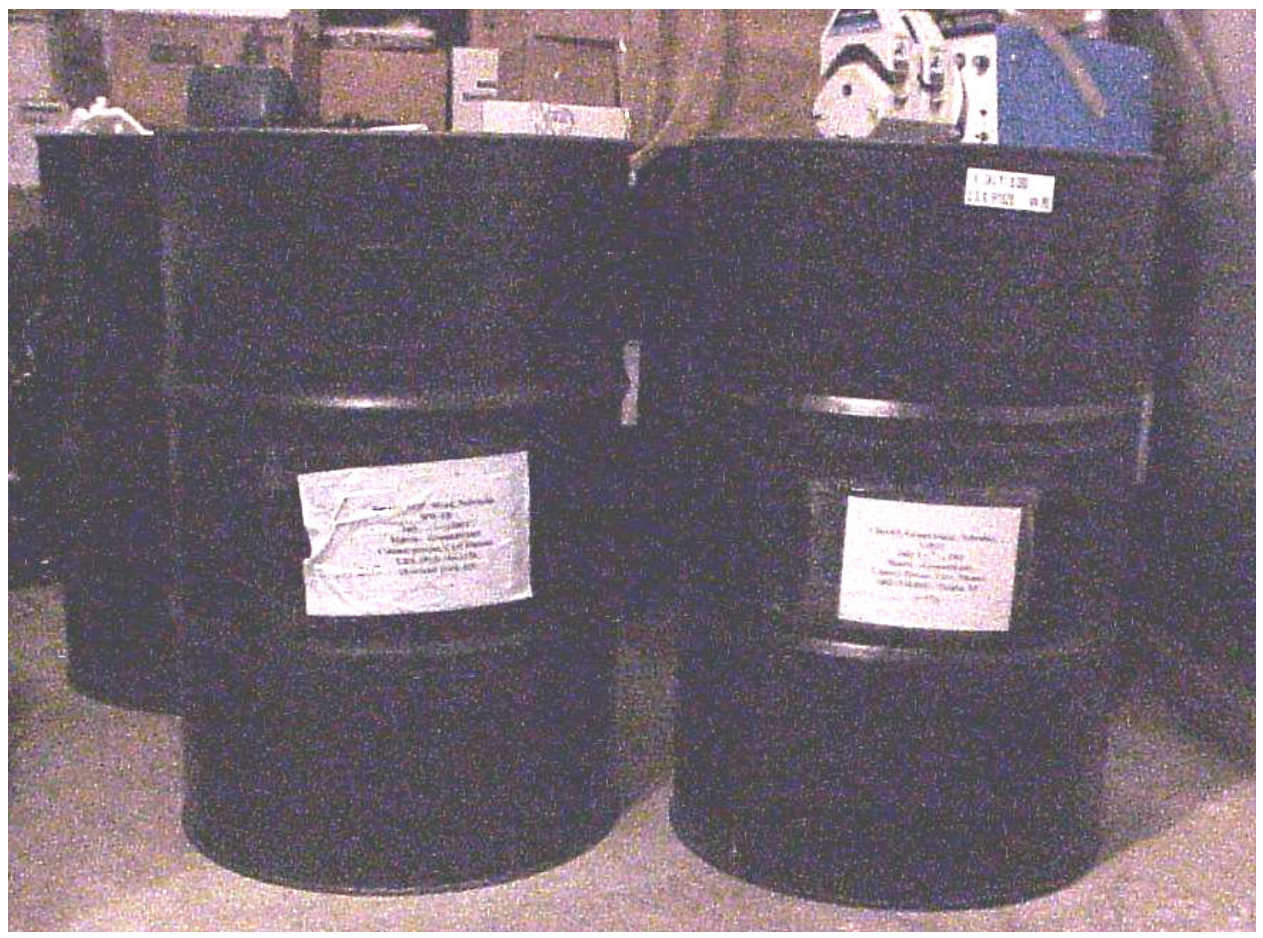

Figure 7. Site groundwater in 210-L (55-gal) drums 


\section{$5 \quad$ Materials and Methods}

\section{Experimental}

Bench-scale column setup comprised of 104-cm (3.4-ft)-long PVC columns with an inside diameter of $3.8 \mathrm{~cm}$ (1.5 in.). Each site (NOP and CHAAP) had five sets of triplicate columns to evaluate four different amendments and a control. The design of the column system is shown in Figure 8.

The inside diameter of these columns was larger than that of the acetate liner, which resulted in a reduction of total height between the soil core and the column. Aquifer material from the acetate liners was slowly emptied into the PVC columns to create minimally disturbed soil cores. Both ends of the columns were closed with PVC caps screened with porous $(100 \mu \mathrm{m}) \mathrm{PVC}$. End caps were fitted with valves for sampling influent and effluent streams. Additional sampling ports were placed along the length of each column to allow for intermediate sampling and development of contaminant bed profiles. These additional ports were necessary for the development of kinetic data. Three intermediate sampling ports located at 26-cm (10.2-in.) intervals divided the entire soil core in each column into four equal sections. These intermediate sampling ports were fitted with 3 -mm (0.12-in.) adapters and tubing clamps. To examine the effects of microbial growth on the hydrodynamic properties (biofouling) of the aquifer material, pressure gauges were placed at the inlet to each column. The pressure drop across the soil cores was monitored to provide information about the buildup of backpressure, indicative of biofouling, induced by microbial activity. Ground-water amended with different carbon sources (electron donors) was forced through the columns by pressurizing the amended groundwater in the inlet reservoir with helium gas. A metering valve controlled the flow of pressurized groundwater through triplicate columns in parallel. Helium was chosen to reduce partial pressure of oxygen in the reservoir because of its inertness. The middle column in each set was equipped with an oxidationreduction potential (ORP) electrode via a flow-through cell to compare the reduced conditions in the effluent stream to that of the inlet reservoir. The column setup is shown in Figure 9. 


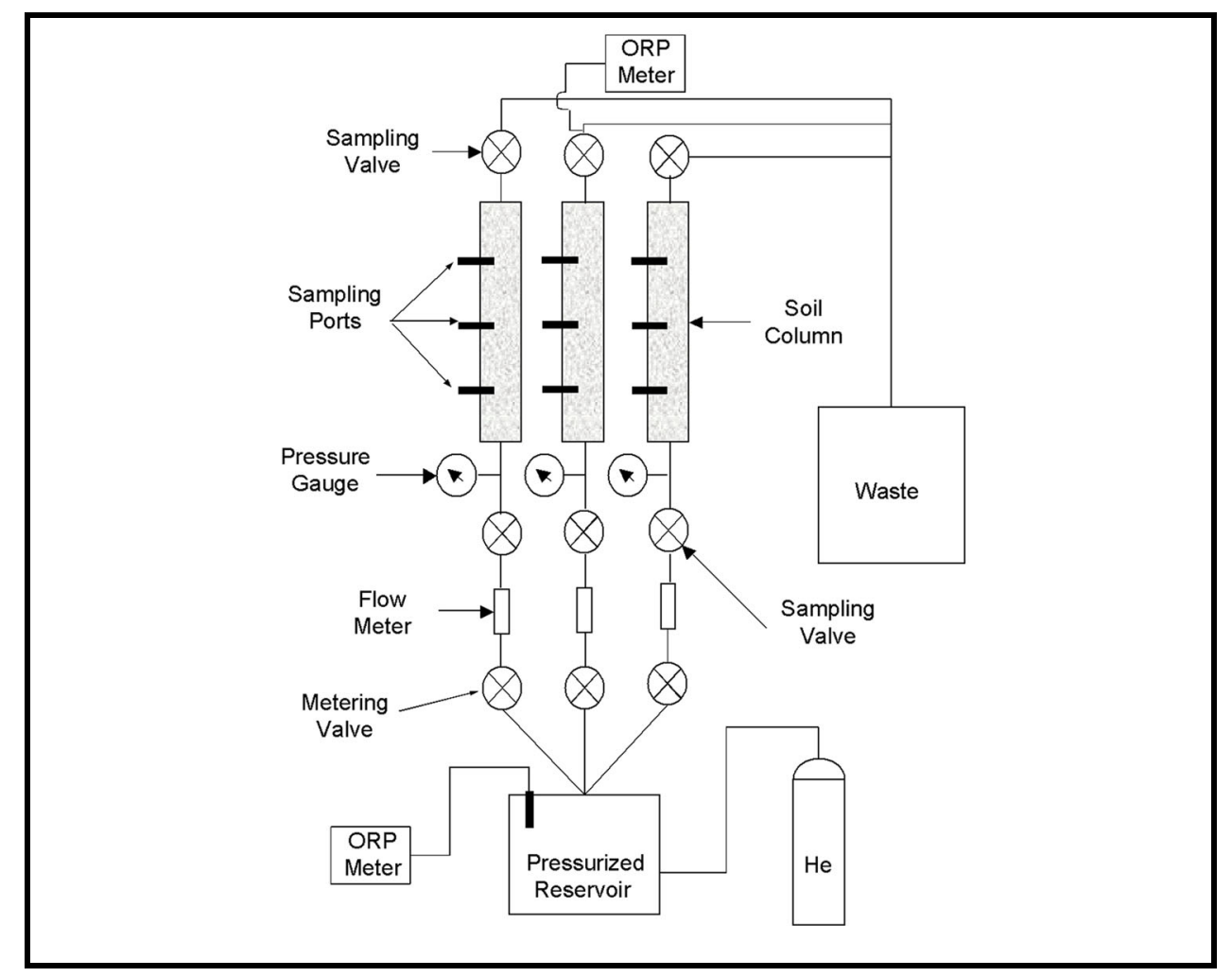

Figure 8. Schematics of column setup

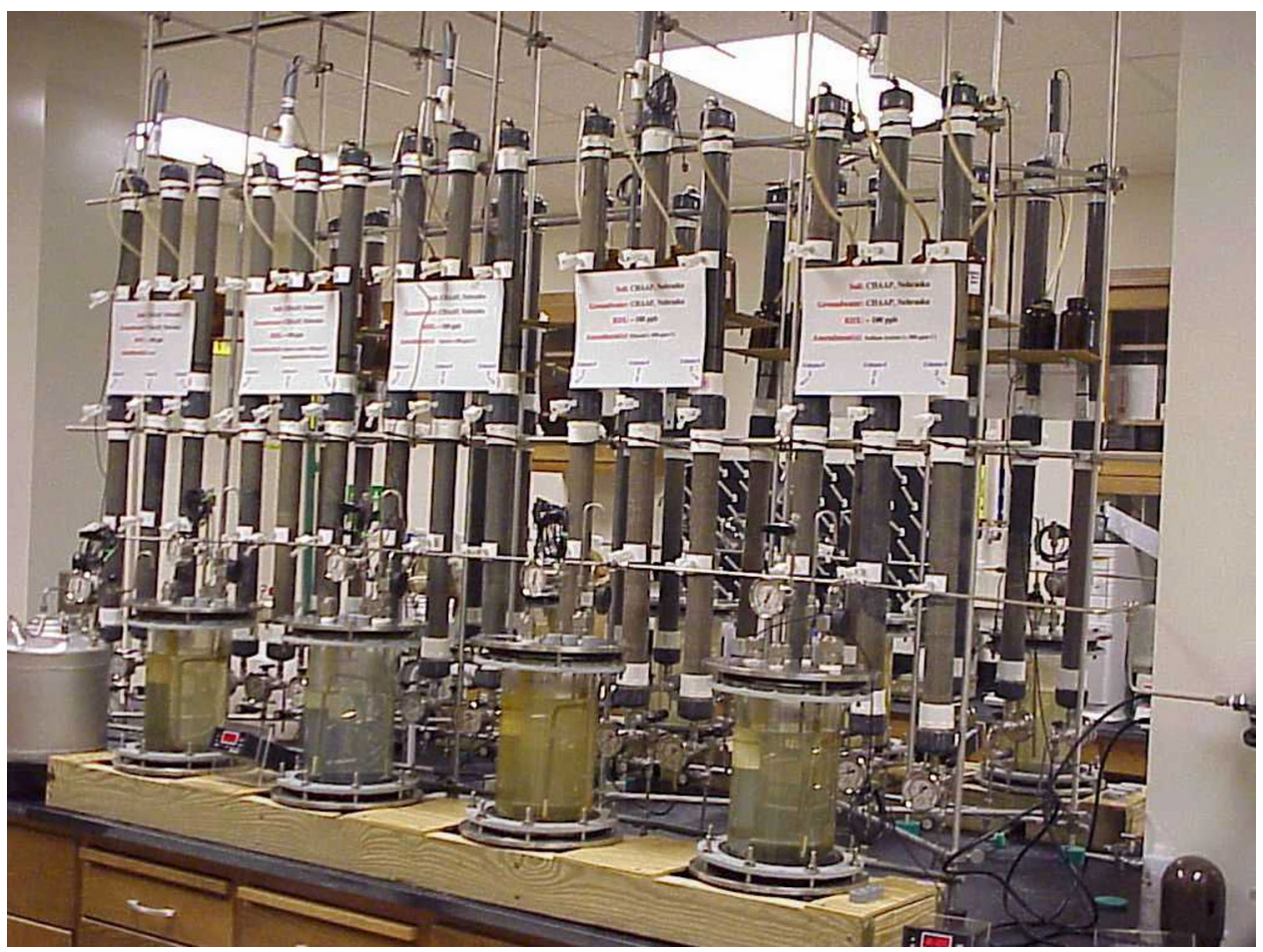

Figure 9. Experimental column setup 


\section{Operation}

The initial concentration of RDX in groundwater from NOP and CHAAP sites ranged between 26 and $66 \mu \mathrm{g} \mathrm{L}^{-1}$. However, because of unknown reasons $\mathrm{RDX}$ was degraded in the storage drums during storage. The groundwater in the inlet reservoir was spiked with RDX at a concentration of about $100 \mu \mathrm{g} \mathrm{L}^{-1}$ to maintain the explosive contamination. Three different carbon sources (electron donors) were used for each site. The carbon sources used were: acetate, ethanol, and soluble starch. In addition to carbon sources, ammonium was also used to evaluate the synergistic benefits of ammonium with the carbon source. Each site had five sets of triplicate columns for evaluating the effects of three carbon sources individually, carbon source plus ammonium, and a carbon source control. An amendment concentration of $500 \mathrm{mg} \mathrm{L}^{-1}$ (as C) was used to ensure excess carbon is available. The operating conditions are summarized in Table 5.

\begin{tabular}{|c|c|c|c|c|c|c|}
\hline \multicolumn{7}{|c|}{$\begin{array}{l}\text { Table } 5 \\
\text { Operating Conditions }\end{array}$} \\
\hline \multirow[b]{2}{*}{$\begin{array}{c}\text { Column } \\
\text { Set \# }\end{array}$} & \multirow{2}{*}{$\begin{array}{c}\text { Groundwater } \\
\text { Flow rate } \\
\mathrm{mL} \mathrm{d}^{-1}\end{array}$} & \multirow{2}{*}{$\begin{array}{c}\text { RDX } \\
\text { Concentration } \\
\mu \mathrm{g} \mathrm{L}^{-1} \\
\end{array}$} & \multicolumn{4}{|c|}{ "Amendment Concentration } \\
\hline & & & $\begin{array}{l}\text { Acetate } \\
\mathrm{mg} \mathrm{L}^{-1} \mathrm{C}\end{array}$ & $\begin{array}{l}\text { Ethanol } \\
\mathrm{mg} \mathrm{L}^{-1} \mathrm{C}\end{array}$ & $\begin{array}{c}\text { Starch } \\
\mathrm{mg} \mathrm{L}^{-1} \mathrm{C}\end{array}$ & $\begin{array}{c}\text { Ammonium } \\
\mathrm{mg} \mathrm{L}^{-1} \mathrm{~N}\end{array}$ \\
\hline 1 & $288 \pm 72$ & $\sim 100$ & $\sim 500$ & 0 & 0 & 0 \\
\hline 2 & $288 \pm 72$ & $\sim 100$ & 0 & $\sim 500$ & 0 & 0 \\
\hline 3 & $288 \pm 72$ & $\sim 100$ & 0 & 0 & $\sim 500$ & 0 \\
\hline 4 & $288 \pm 72$ & $\sim 100$ & $\sim 500$ & 0 & 0 & $\sim 100$ \\
\hline 5 & $288 \pm 72$ & $\sim 100$ & 0 & 0 & 0 & 0 \\
\hline
\end{tabular}

For each amendment the triplicate columns were operated in parallel with common feed (Figure 8). Groundwater flow through each column was initiated at $0.2 \pm 0.05 \mathrm{~mL} \mathrm{~min}^{-1}$ and maintained at this rate for the duration of the study. Groundwater samples were collected from inlet and outlet sampling ports weekly. Samples from all the ports along the height of the column were collected twice during the study for bed profile determination. Groundwater samples were stored in a freezer until extraction for RDX and amendment analysis.

\section{Analytical Techniques}

Acetate and other common ionizable groundwater constituents (sulfate, nitrate, etc.) analyses were performed using a DIONEX Ion Chromatograph. Chemical separation and detection was achieved using an Ionpac AS11 analytical column $(4 \times 250 \mathrm{~mm})$ and a Dionex conductivity detector $(1.25-\mu \mathrm{L}$ internal volume). The mobile phase consists of $\mathrm{NaOH}$ at a flow rate of $1.5 \mathrm{~mL} \mathrm{~min}$. The sample volume was $25 \mu \mathrm{L}$ of filtered sample $(0.45 \mu \mathrm{m})$. The instrument was calibrated daily from standards prepared from stock solutions. Check standards were run after every 10 samples. 
Ammonium concentration in groundwater was analyzed by using Lachat. QuickChem Method 10-107-06-1-D using sodium phenolate, sodium hypochlorite, and sodium nitroprusside as reagents was employed. The method is based on Berthelot reaction. Ammonia reacts with alkaline phenol, then with sodium hypochlorite to form indophenol blue. Sodium nitroprusside is added to enhance the sensitivity. The absorbance of reaction product was measured at $630 \mathrm{~nm}$. The relative absorbance at this wavelength is directly proportional to the original ammonia concentration in the rage of 2 to $100 \mathrm{mg} \mathrm{L}^{-1}$ (as $\mathrm{N}$ ).

$\mathrm{RDX}$ analysis in the groundwater involved preconcentrating of water samples by solid phase extraction (SPE) with Waters Porapak ${ }^{\circledR}$ RDX Sep-Pak ${ }^{\circledR}$ Vac Cartridges. As water samples are drawn through the SPE cartridges, nitroaromatic and nitramine compounds present in the water are adsorbed onto the copolymer material of the SPE cartridges. The adsorbed compounds are then eluted from the columns with acetonitrile, which is collected for analysis. Analysis was performed using a Waters 610 Fluid Unit pump, a Waters 717 plus autosampler including a 200- $\mu \mathrm{L}$ loop injector and a Waters 486 tunable UV absorbance detector monitored at $245 \mathrm{~nm}$. The injection volume is $50 \mu \mathrm{L}$. Millenium 2.1 Chromatography software was used for data analysis. Chemical separation is achieved using a Supelco LC-18 reverse phase HPLC column $(25 \mathrm{~cm} \times 4.6 \mathrm{~mm}(5 \mu \mathrm{m}))$ with a Novapak C-18 precolumn for the primary column. The mobile phase is $(1: 1(\mathrm{v} / \mathrm{v})$ methanol/organic-free reagent water) at a flow rate of $1.2 \mathrm{~mL} \mathrm{~min}^{-1}$. For EPA Method 8330 analytes, a seven-point calibration curve was utilized. For analysis of breakdown products of the 8330 analytes, a five-point calibration curve was utilized. Daily calibration consists of running a second source standard and a continuing calibration verification standard at the beginning of the analytical run. A midpoint calibration standard was run after every 10 samples. Standards were prepared from stock primary source standard solutions, which were obtained from the Army Environmental Center, Aberdeen Proving Ground, and secondary source standard solutions, which were obtained from Ultra Scientific.

\section{Hydrodynamics and Biodegradation Kinetics}

A tracer test was performed to evaluate the hydrodynamic properties of the soil columns. This test was performed by adding chloride at nontoxic levels and sampling the effluent periodically to develop breakthrough curves. An advection-dispersion model (Eq 1) was fitted to the data to determine dispersivity and porosity.

$$
\frac{\partial \mathrm{C}}{\partial \mathrm{t}}=\alpha \mathrm{v} \frac{\partial^{2} \mathrm{C}}{\partial \mathrm{x}^{2}}-\mathrm{v} \frac{\partial \mathrm{C}}{\partial \mathrm{x}}
$$

where

$$
\begin{aligned}
\mathrm{C} & =\text { chloride concentration }\left(\mathrm{M} \mathrm{L}^{-3}\right) \\
\mathrm{t} & =\operatorname{time} \text { elapsed }(\mathrm{t}) \\
\alpha & =\text { dispersivity }(\mathrm{L}) \\
\mathrm{v} & =\text { aquifer material porosity }
\end{aligned}
$$




$$
\mathrm{x}=\text { aquifer length }(\mathrm{L})
$$

Given the boundary conditions, $\mathrm{C}(0, \mathrm{t})=\mathrm{C}_{0} ; \mathrm{C}(\infty, \mathrm{t})=0$; and $\mathrm{C}(\mathrm{x}, 0)=\mathrm{C}_{\mathrm{i}}$, the solution to Equation 1 is shown in Equation 2:

$$
\mathrm{C}=\frac{\mathrm{C}_{0}}{2}\left[\operatorname{erfc}\left(\frac{\mathrm{x}-\mathrm{vt}}{2 \sqrt{\alpha \mathrm{vt}}}\right)+\exp \left(\frac{\mathrm{x}}{\alpha}\right) \operatorname{erfc}\left(\frac{\mathrm{x}+\mathrm{vt}}{2 \sqrt{\alpha \mathrm{vt}}}\right)\right]
$$

This information was used to determine operation parameters of the columns and any subsequent kinetics derivation.

Hydraulic conductivity (permeability) of the aquifer material was estimated from Darcy's law (Eq 3) by varying the groundwater flow rate and monitoring the head loss across the column.

$$
q=-K A\left(\frac{h_{\text {out }}-h_{\text {in }}}{L}\right)
$$

where

$$
\begin{aligned}
\mathrm{q} & =\text { groundwater flow rate }\left(\mathrm{L}^{3} \mathrm{t}^{-1}\right) \\
\mathrm{K} & =\text { hydraulic conductivity }\left(\mathrm{L} \mathrm{t}^{-1}\right) \\
\mathrm{A} & =\text { area of cross section of the column }\left(\mathrm{L}^{2}\right) \\
\mathrm{h}_{\text {in }} \text { and } \mathrm{h}_{\text {out }} & =\text { head loss at column inlet and outlet, respectively }(\mathrm{L}) \\
\mathrm{L} & =\text { aquifer length in the column }(\mathrm{L}) .
\end{aligned}
$$

Since $\mathrm{h}=\frac{\mathrm{P}}{\rho \mathrm{g}}$, Equation 3 simplifies to Equation 4 as follows:

$$
P_{\text {in }}=\left(\frac{L \rho g}{K A}\right) q+P_{\text {out }}
$$

where

$$
\begin{aligned}
\mathrm{P}_{\text {in }} \text { and } \mathrm{P}_{\text {out }}= & \underset{\text { gauge pressure at column inlet and outlet, respectively }}{\left(\mathrm{M} \mathrm{L}^{-1} \mathrm{t}^{-2}\right)} \\
\rho= & \text { density of water }\left(\mathrm{M} \mathrm{L}^{-3}\right) \\
\mathrm{g}= & \text { acceleration of gravitational }\left(\mathrm{L} \mathrm{t}^{-2}\right) .
\end{aligned}
$$

From Equation 4, in a plot of $\mathrm{P}_{\text {in }}$ versus $\mathrm{q}$, the slope is a function of hydraulic conductivity as given in Equation 5.

$$
\text { slope }=\frac{\mathrm{L} \rho g}{\mathrm{KA}}
$$

The rate of transformation of RDX was determined by sampling at ports placed at intermediate points in the columns. A contaminant profile was developed and an advection-dispersion model (Eq 6) for contaminant transport with decay was fitted to the results. This sampling along column length was done on week 16, 
when the operating conditions were steady and columns had reached equilibrium conditions with steady RDX removal.

$$
\frac{\partial \mathrm{C}}{\partial \mathrm{t}}=\alpha \mathrm{v} \frac{\partial^{2} \mathrm{C}}{\partial \mathrm{x}^{2}}-\mathrm{v} \frac{\partial \mathrm{C}}{\partial \mathrm{x}}-\mathrm{kC}
$$

where $\mathrm{k}$ is the RDX biodegradation rater constant $\left(\mathrm{t}^{-1}\right)$.

With these boundary conditions, $\mathrm{C}(0, \mathrm{t})=\mathrm{C}_{0} ; \mathrm{C}(\infty, \mathrm{t})=0$; and $\mathrm{C}(\mathrm{x}, 0)=0$, at steady state, Equation 6 can be solved to Equation 7 as follows:

$$
\mathrm{C}=\mathrm{C}_{0} \exp \left[\left(\frac{\mathrm{x}}{2 \alpha \mathrm{v}}\right)\left(\mathrm{v}-\sqrt{\mathrm{v}^{2}+4 \mathrm{k} \alpha \mathrm{v}}\right)\right]
$$

\section{Toxicological Analysis}

Toxicological assays were conducted on liquid aliquots of column influent and effluent samples. RDX cytotoxicity was evaluated using a strain of bioluminescent bacteria, Vibrio fischeri. Freeze-dried $V$. fischeri and reagents for the bioassay were obtained from Azur Scientific (Carlsbad, CA). A proportionate quantity of salt medium was added to each aqueous RDX sample. Samples were serially diluted to evaluate the effect of sample concentration on cytotoxicity. Bacterial bioluminescence was measured following 5- and 15-min incubation using a Microtox ${ }^{\circledR}$ M500 analyzer (Azur Scientific, CA). The results are reported as $\mathrm{EC}_{50}$ values, the effective concentration where 50 percent of the expected fluorescence from the test bacterium, V. fischeri, was inhibited. Higher $\mathrm{EC}_{50}$ values indicate lower acute toxicity. 


\section{Results}

\section{Initial Characterization}

The aquifer material collected from NOP site was predominantly alluvial sand, and the material from CHAAP site was a mixture of alluvial sand and gravel. Results of initial characterization of groundwater from both sites are summarized inTable 6. Groundwater from NOP site was higher in explosive (RDX and TNT) concentration as compared to CHAAP site. Concentration of other groundwater constituents like chloride, nitrate, sulfate, etc., was also low in CHAAP groundwater in comparison to NOP. However, groundwater from both sites was at a neutral $\mathrm{pH}(7.6)$.

\begin{tabular}{|l|c|c||}
\hline \multicolumn{3}{|l||}{ Table 6} \\
Initial Characterization of Groundwater \\
\hline \hline Constituent & NOP & CHAAP \\
\hline \hline RDX & $66.8 \mu \mathrm{L} \mathrm{L}^{-1}$ & $26.2 \mu \mathrm{g} \mathrm{L}^{-1}$ \\
TNT & $17.4 \mu \mathrm{g} \mathrm{L}^{-1}$ & $2.2 \mu \mathrm{g} \mathrm{L}^{-1}$ \\
Chloride $(\mathrm{Cl})$ & $9.56 \mathrm{mg} \mathrm{L}^{-1}$ & $3.78 \mathrm{mg} \mathrm{L}^{-1}$ \\
Nitrate $\left(\mathrm{NO}_{3}^{-}\right)$ & $22.0 \mathrm{mg} \mathrm{L}^{-1}$ & $14.3 \mathrm{mg} \mathrm{L}^{-1}$ \\
Nitrite $\left(\mathrm{NO}_{2}^{-}\right)$ & $4.97 \mathrm{mg} \mathrm{L}^{-1}$ & $3.44 \mathrm{mg} \mathrm{L}^{-1}$ \\
Sulfate $\left(\mathrm{SO}_{4}^{-}\right)$ & $49.4 \mathrm{mg} \mathrm{L}^{-1}$ & $29.5 \mathrm{mg} \mathrm{L}^{-1}$ \\
pH & 7.6 & 7.6 \\
\hline
\end{tabular}

\section{Column Hydrodynamics}

The results of tracer tests on NOP aquifer material in Column Set \#1 are shown in Figure 10. Table 7 summarizes the porosity and diffusivity of aquifer material in individual columns. These tracer tests revealed that the aquifer material from NOP site is more porous with an effective porosity of $0.28 \pm 0.06$ and dispersivity ranging between 0.28 to $11.6 \mathrm{~cm}$ (0.11 to $4.5 \mathrm{in}$.). In comparison to NOP site, the aquifer material from CHAAP site is denser with an effective porosity of $0.23 \pm 0.06$ and dispersivity range of 0.25 to $6.8 \mathrm{~cm}(0.1$ to 2.7 in.). The measured porosities are well within the values expected for a sandy soil. However, the dispersivities are smaller than would be expected in the field but are acceptable for laboratory evaluations. Based on this porosity data and an 


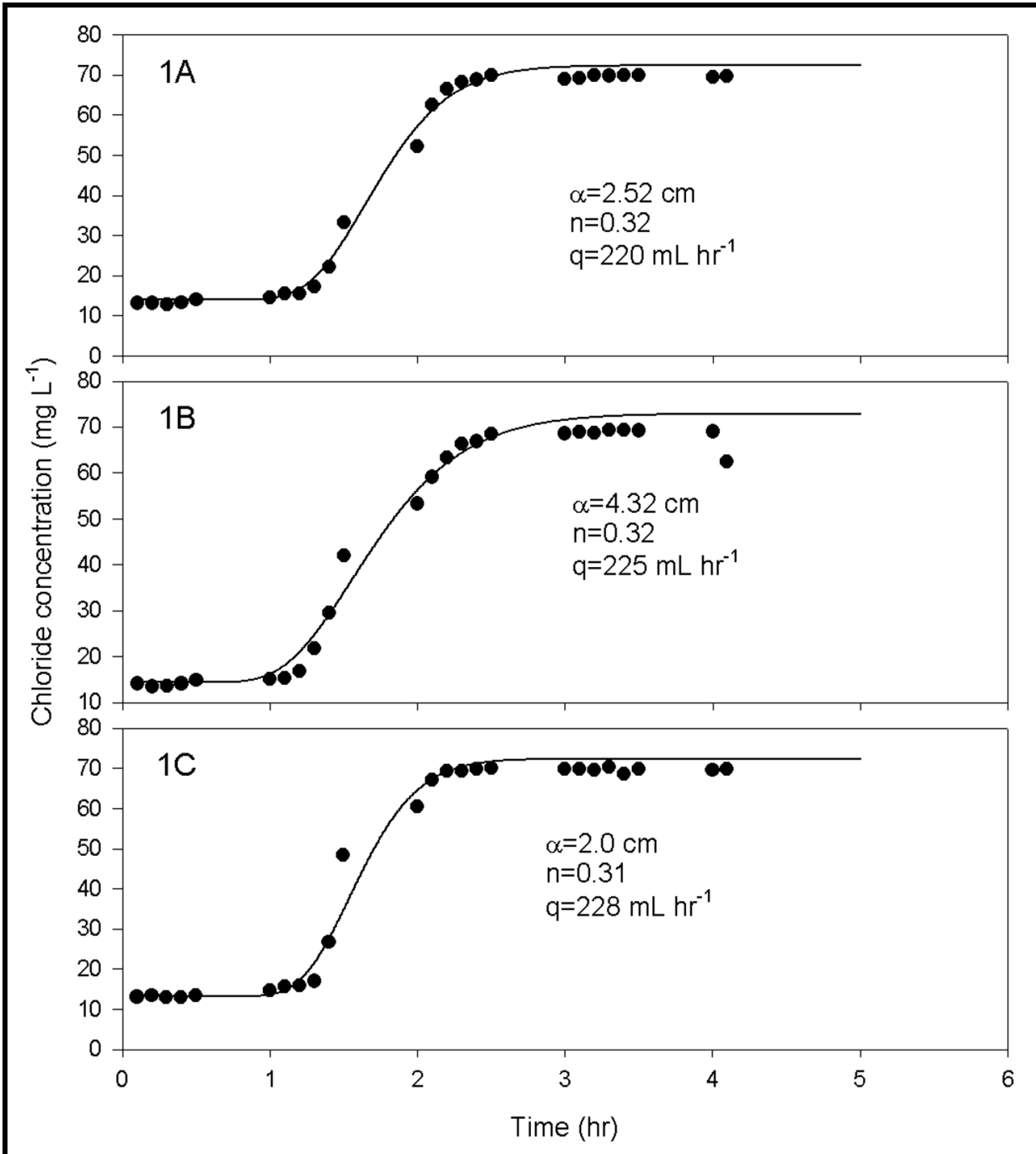

Figure 10. Chloride tracer breakthrough curve for NOP Column Set \#1

average design flow rate of $288 \mathrm{~mL} \mathrm{~d}^{-1}$, the average residence time for groundwater in NOP soil columns was approximately $27.5 \mathrm{hr}$ as compared to $22.6 \mathrm{hr}$ in CHAAP soil columns. Although the individual columns for each site were packed with the same aquifer material, there were differences in bed porosity because of column packing. Plots of tracer test for individual columns are given in Appendix B.

Figure 11 depicts the hydraulic conductivity of aquifer material from NOP site in Column Set \# 1. The hydraulic conductivity of two aquifer materials did not vary significantly. It ranged between $1.2 \times 10^{-3}$ and $9.8 \times 10^{-4} \mathrm{~cm} \mathrm{sec}^{-1}$

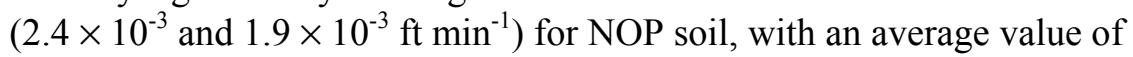
$2.5 \times 10^{-3} \mathrm{~cm} \mathrm{sec}^{-1}\left(4.9 \times 10^{-3} \mathrm{ft} \mathrm{sec}^{-1}\right)$. CHAAP aquifer material had a lower hydraulic conductivity ranging between $1.1 \times 10^{-3}$ and $9.4 \times 10^{-5} \mathrm{~cm} \mathrm{sec}^{-1}$ $\left(2.2 \times 10^{-3}\right.$ and $\left.1.9 \times 10^{-4} \mathrm{ft} \mathrm{min}^{-1}\right)$ with an average value of $1.6 \times 10^{-3} \mathrm{~cm} \mathrm{sec}^{-1}$ $\left(3.2 \times 10^{-3} \mathrm{ft} \mathrm{min}^{-1}\right)$. The measured hydraulic conductivity for the two aquifer 


\begin{tabular}{|c|c|c|c|c|c|c|c|}
\hline \multicolumn{8}{|c|}{$\begin{array}{l}\text { Table } 7 \\
\text { Porosity and Diffusivity of Aquifer Material in Each Column }\end{array}$} \\
\hline \multirow{2}{*}{\multicolumn{2}{|c|}{ Column Tag }} & \multicolumn{3}{|c|}{ NOP } & \multicolumn{3}{|c|}{ CHAAP } \\
\hline & & $\begin{array}{l}\text { Disper- } \\
\text { sivity } \\
\mathrm{cm}\end{array}$ & Porosity & $\begin{array}{l}\text { Flow } \\
\text { Rate } \\
\mathrm{mL} \mathrm{hr}^{-1}\end{array}$ & $\begin{array}{l}\text { Disper- } \\
\text { sivity } \\
\mathrm{cm}\end{array}$ & Porosity & $\begin{array}{l}\text { Flow } \\
\text { Rate } \\
\mathrm{mL} \mathrm{hr}^{-1}\end{array}$ \\
\hline 1) Acetate & $\begin{array}{l}\text { A } \\
\text { B } \\
\text { C }\end{array}$ & $\begin{array}{l}2.52 \\
4.32 \\
2.00\end{array}$ & $\begin{array}{l}0.32 \\
0.32 \\
0.31\end{array}$ & $\begin{array}{l}220.57 \\
225.22 \\
227.88\end{array}$ & $\begin{array}{l}5.47 \\
0.76 \\
1.83\end{array}$ & $\begin{array}{l}0.15 \\
0.28 \\
0.20\end{array}$ & $\begin{array}{l}465.60 \\
295.80 \\
465.00\end{array}$ \\
\hline 2) Ethanol & $\begin{array}{l}\text { A } \\
\text { B } \\
\text { C }\end{array}$ & $\begin{array}{l}0.95 \\
0.42 \\
0.98 \\
\end{array}$ & $\begin{array}{l}0.30 \\
0.36 \\
0.36 \\
\end{array}$ & $\begin{array}{l}236.19 \\
202.45 \\
157.96 \\
\end{array}$ & $\begin{array}{l}0.86 \\
0.33 \\
0.87 \\
\end{array}$ & $\begin{array}{l}0.18 \\
0.19 \\
0.20 \\
\end{array}$ & $\begin{array}{l}414.42 \\
407.26 \\
464.28 \\
\end{array}$ \\
\hline 3) Starch & $\begin{array}{l}\text { A } \\
\text { B } \\
\text { C }\end{array}$ & $\begin{array}{c}1.50 \\
2.86 \\
11.62 \\
\end{array}$ & $\begin{array}{l}0.31 \\
0.33 \\
0.25 \\
\end{array}$ & $\begin{array}{c}218.31 \\
243.21 \\
60.22 \\
\end{array}$ & $\begin{array}{l}4.88 \\
0.25 \\
0.35 \\
\end{array}$ & $\begin{array}{l}0.30 \\
0.36 \\
0.23 \\
\end{array}$ & $\begin{array}{c}65.75 \\
133.13 \\
119.90 \\
\end{array}$ \\
\hline $\begin{array}{l}\text { 4) Acetate+ } \\
\text { Ammonium }\end{array}$ & $\begin{array}{l}\text { A } \\
\text { B } \\
\text { C }\end{array}$ & $\begin{array}{l}0.52 \\
0.36 \\
2.00\end{array}$ & $\begin{array}{l}0.18 \\
0.20 \\
0.20\end{array}$ & $\begin{array}{l}470.22 \\
456.54 \\
458.22\end{array}$ & $\begin{array}{l}6.78 \\
3.69 \\
5.00\end{array}$ & $\begin{array}{l}0.27 \\
0.28 \\
0.19\end{array}$ & $\begin{array}{l}27.96 \\
57.19 \\
85.87\end{array}$ \\
\hline 5) Control & $\begin{array}{l}\text { A } \\
\text { B } \\
\text { C }\end{array}$ & $\begin{array}{l}0.65 \\
3.43 \\
1.28\end{array}$ & $\begin{array}{l}0.26 \\
0.25 \\
0.27\end{array}$ & $\begin{array}{l}223.59 \\
169.17 \\
233.70\end{array}$ & $\begin{array}{l}2.10 \\
0.67 \\
1.08\end{array}$ & $\begin{array}{l}0.18 \\
0.20 \\
0.19\end{array}$ & $\begin{array}{l}156.39 \\
172.52 \\
172.52\end{array}$ \\
\hline
\end{tabular}

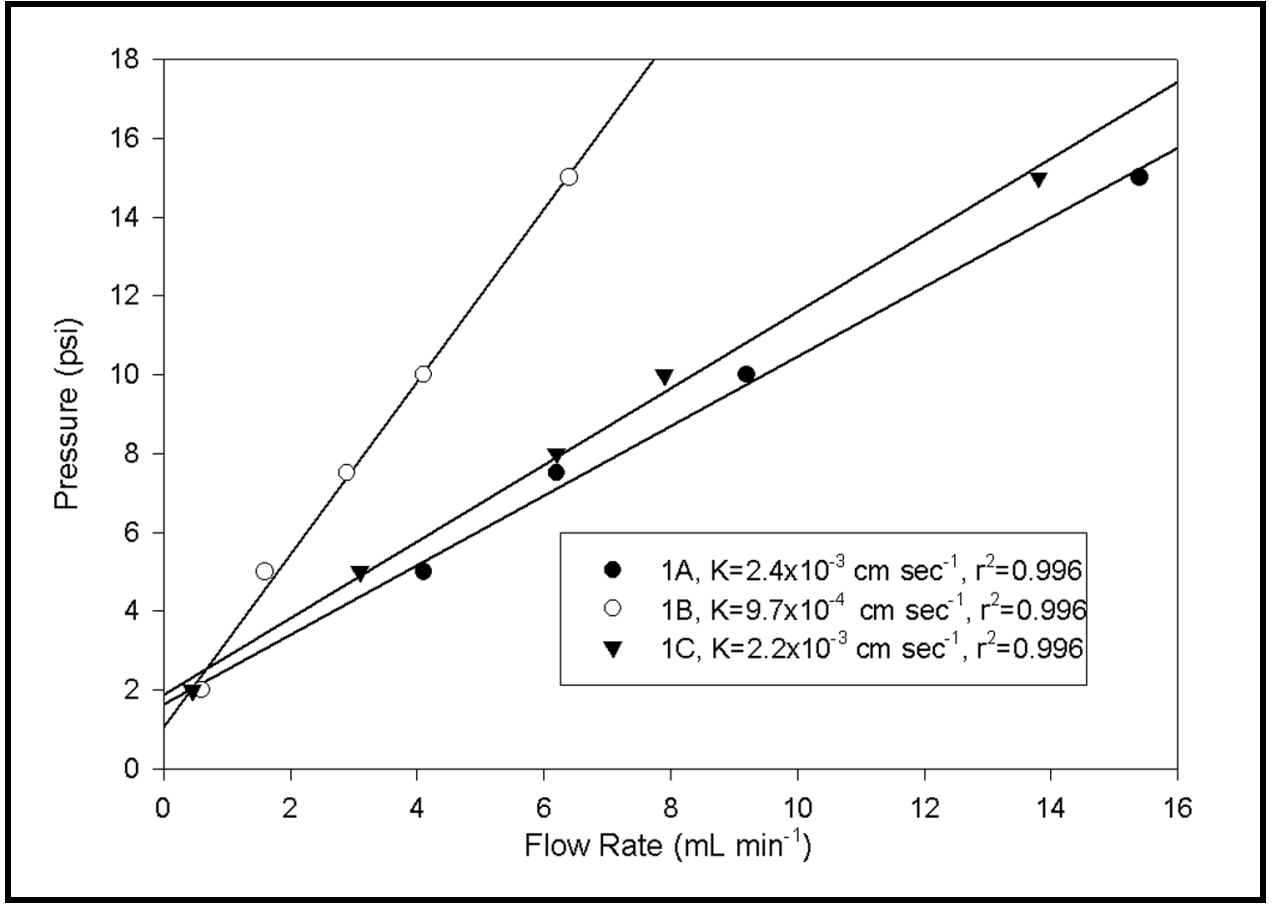

Figure 11. Hydraulic conductivity of NOP aquifer material in Column Set \#1

materials falls within the range expected for a sandy soil. The large range of values for the hydraulic conductivity can be attributed to the gravel present in the aquifer material. The hydraulic conductivity data for each soil column is summarized in Table 8, and the individual plots are shown in Appendix B. 


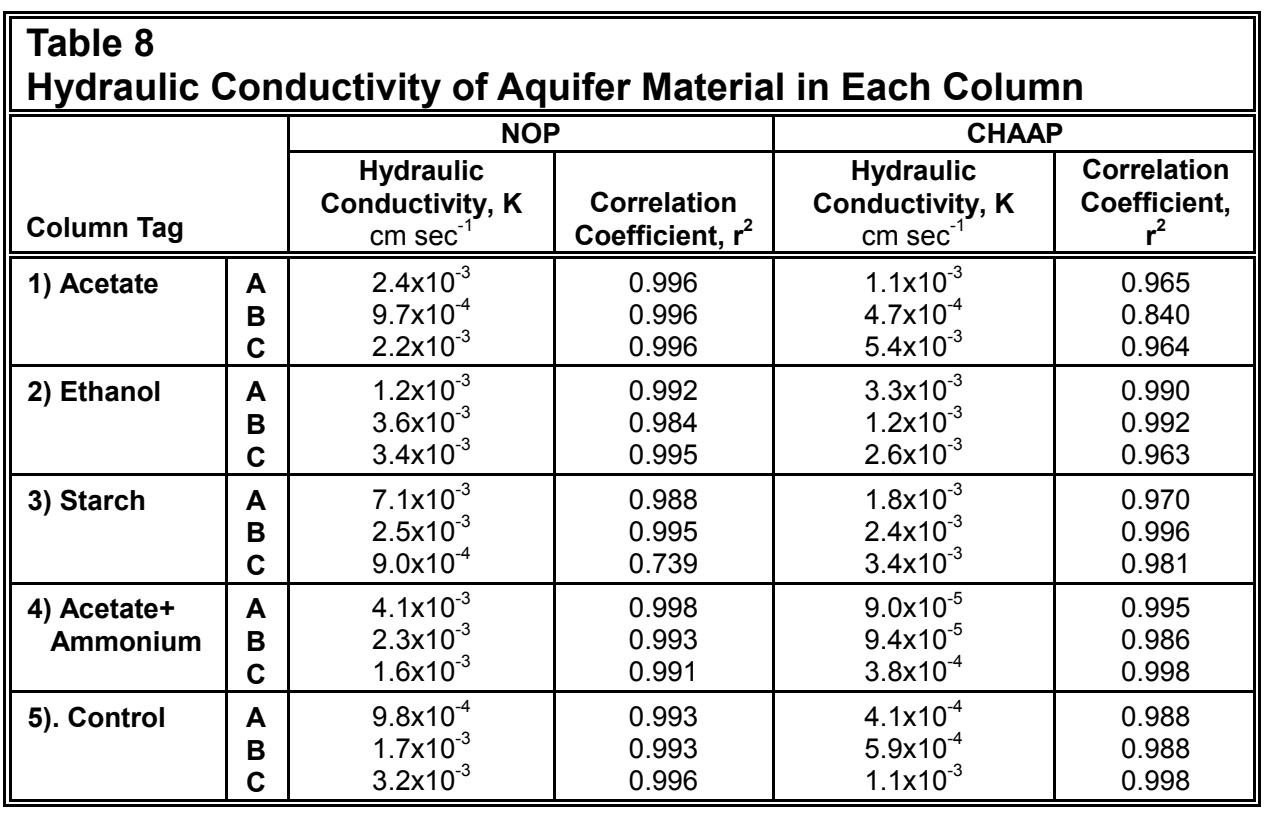

Plots of operating conditions (groundwater flow rate, influent and effluent redox, and backpressure) for individual column are shown in Figures B21 to B30 (Appendix B). There was no significant backpressure buildup in any of the columns during the entire 17-week study. Flow rates varied around the $290-\mathrm{mL} \mathrm{d}^{-1}$ designed flow rate because of variations in packed bed in each column. Effluent from each column was very reduced and significant drop in redox potential between inlet and outlet streams was observed in all the columns. Anaerobic conditions were established in soil columns by providing carbon source to indigenous microorganisms, which then utilized oxygen, creating reduced environment. For example, in NOP Column 1B, amended with acetate as carbon source, $\mathrm{E}_{\mathrm{h}}$ dropped from initial value of $+200 \mathrm{mV}$ to about $-300 \mathrm{mV}$ (Figure 12). These changes in the redox potential were partially the result of the use of helium gas for pressurizing water in the inlet pressure reservoirs for feeding groundwater to individual columns. Noticeable reduction in redox potential was observed in pressure reservoirs because of the use of helium that reduced the partial pressure of oxygen in feed water. The use of helium artificially induced the reducing conditions. This phenomenon will not be present in any field activities because competition for electrons will occur from additional oxidants in the aquifer such as oxygen, and other inorganic electron scavengers like nitrate, sulfate. The removal of dissolved oxygen and inducement of reducing conditions must and will be taken into account when developing the field-scale demonstration plan.

\section{RDX Bioremediation}

RDX, concentrations (about $100 \mu \mathrm{g} \mathrm{L}^{-1}$ in groundwater) were remediated to below detection levels of $1 \mu \mathrm{g} \mathrm{L}^{-1}$ in each column regardless of the type of carbon source (electron donor) used. Individual plots of RDX removal in each column are summarized in Appendix B, Figures B31 through B40. Figure 13 


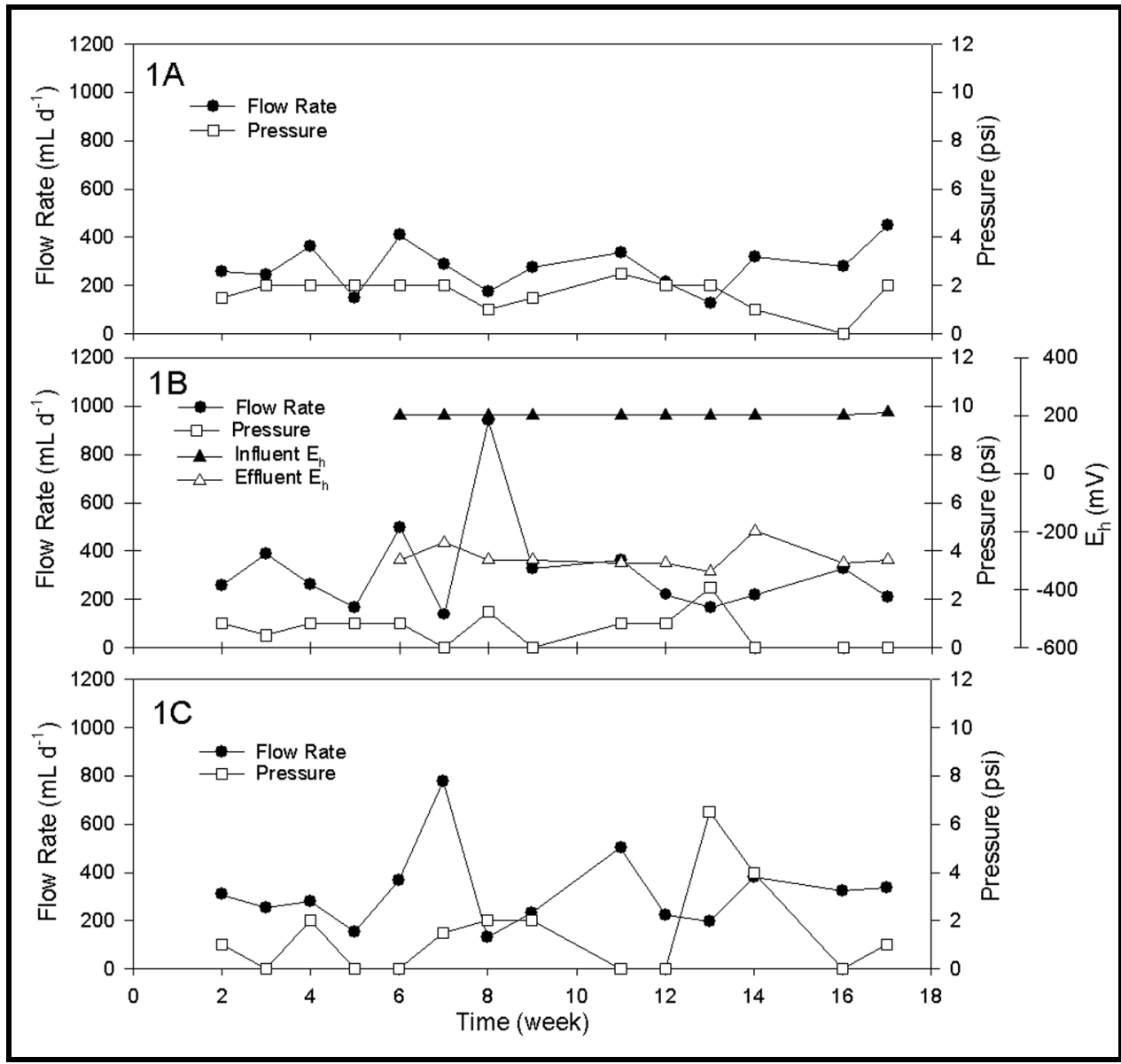

Figure 12. Column operating parameters for NOP Column Set \#1

shows the RDX profile in influent and effluent streams from Column Set \# 1 for NOP site using acetate as electron donor. Variations in the concentration of RDX in influent stream resulted from the degradation of some RDX in the pressure reservoirs under reduced conditions. These variations were more pronounced in pressure reservoirs with soluble starch as electron donor, probably because of high population of RDX degraders (Figure B33, Appendix B).

One noticeable observation with ethanol and soluble starch was the partial conversion of these carbon sources to acetate in pressure reservoirs as well as in columns under reduced conditions. Conversion of ethanol to acetate was more pronounced than the soluble starch, and noticeable concentrations of acetate in the effluent from columns using ethanol as electron donor were observed (Figure B32).

During the 17-week study, RDX was completely removed from the groundwater without the presence of any nitroso-substituted transformation byproducts. Transient traces of MNX, DNX, and TNX were observed in the column effluent. This phenomenon has been reported for various RDX-metabolizing cultures that used organic electron donors (Freedman and Sutherland 1998; Hawari et al. 2000; McCormick, Cornell, and Kaplan 1981). In this study, however, the ultimate fate of RDX appears to be nonvolatile metabolites other than MNX, 


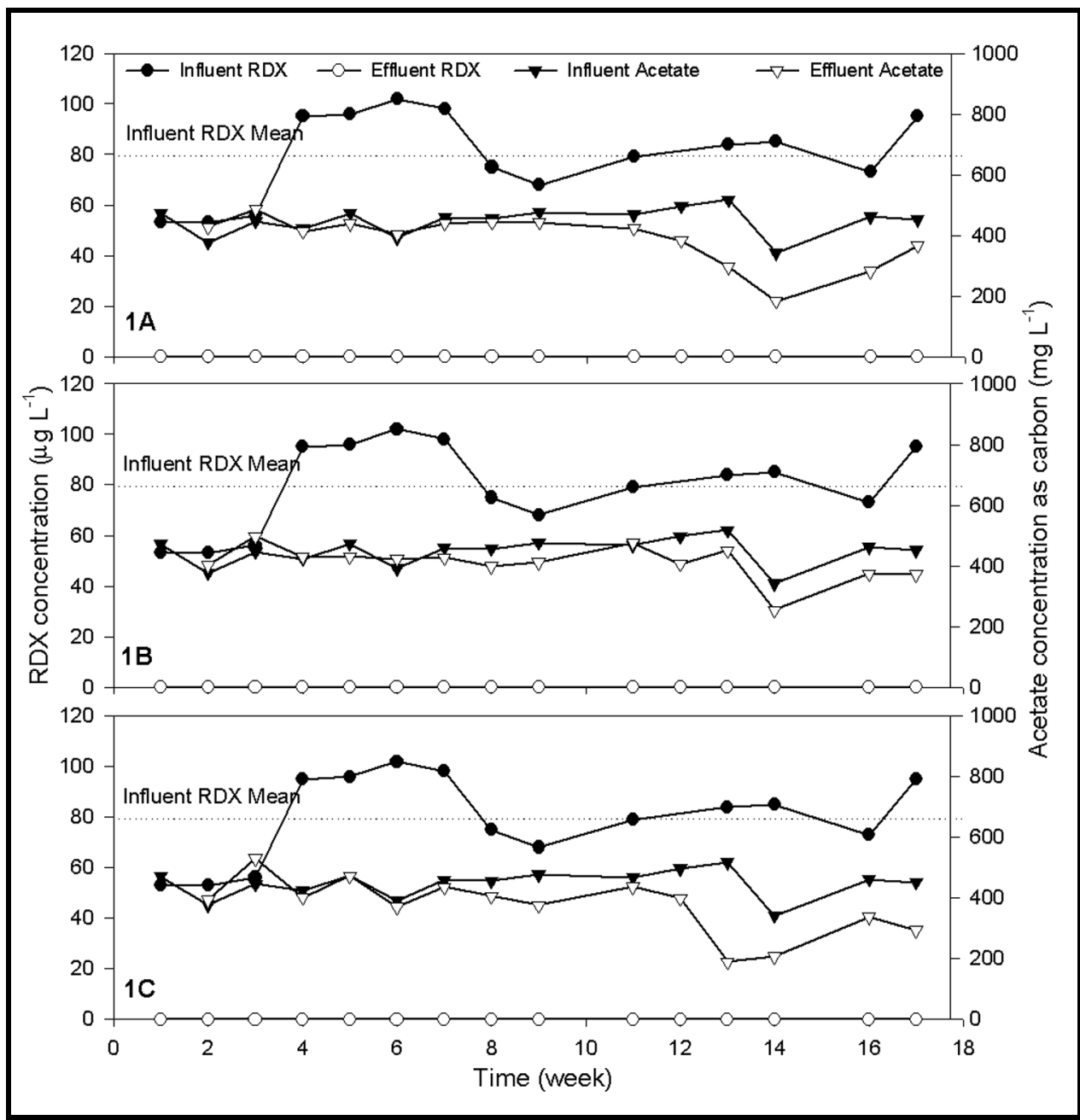

Figure 13. RDX removal from NOP groundwater amended with acetate (Acetate concentration $=500 \mathrm{mg} \mathrm{L}^{-1}$ as $\mathrm{C}$ )

DNX, and TNX, because none of these transformation products were identified in the effluent stream. Similar results of nonnitroso-substituted biotransformation of $\left[{ }^{14} \mathrm{C}\right] \mathrm{RDX}$ by aquifer microorganisms have been reported by Beller (2002). The researcher reported that nonvolatile metabolites MNX, DNX, and TNX constituted $\leq 0.5$ percent of the total RDX carbon. Metabolites that have been previously identified in anaerobic RDX biodegradation and may have been included with nonvolatile metabolites in this study include hydrazine, dimethylhydrazine, methylenedinitramine, bis(hydroxymethyl)nitramine, formaldehyde and methanol (Hawari et al. 2000; McCormick, Cornell, and Kaplan 1981). In the present study, specific analyses to identify these compounds were not performed.

RDX removal was predominantly biological, because RDX degradation was near instantaneous. In case of any abiotic removal such as RDX sorption on the aquifer material during initial days, the removal rate would have declined after equilibrium with the adsorption sites on the soil during the biological acclimation phase. It was not observed. Therefore, analysis of RDX adsorption on aquifer 
material was not conducted. The primary contaminant - RDX, and its possible transformation products - MNX, DNX, and TNX - are soluble with less affinity for sorption to soil surface (Singh et al. 1998; Sheremata et al. 2001). This conclusion of biotic degradation of RDX was also supported by the evidence of degradation of RDX in pressure reservoirs under reduced conditions created by using helium for pressurizing the groundwater.

\section{RDX Biodegradation Kinetics}

RDX biodegradation kinetic parameters for the two aquifer materials studied are summarized in Table 9. The rate of biotransformation of RDX in columns was evaluated from the RDX degradation profile along the column length.

Samples were collected from intermediate ports along column length on week 16, when columns were operating at equilibrium with steady RDX removal. With an average residence time of $27.5 \mathrm{hr}$ in NOP columns and $22.6 \mathrm{hr}$ in CHAAP columns, about 98 and 118 bed volumes of groundwater were treated in the NOP and CHAAP columns, respectively, by week 16 when bed profile sampling was performed to estimate RDX kinetic parameters. The operating conditions were steady and the redox potential in each column was very low (Appendix B, Figures B21 through B30).

\begin{tabular}{|c|c|c|c|}
\hline $\begin{array}{l}\text { Table } 9 \\
\text { Biodegrad } \\
\text { Material }\end{array}$ & & $s$ of RDX in & AAP Aquifer \\
\hline Column Tag & & $\begin{array}{c}\text { NOP } \\
\text { Rate Constant, k } \\
\text { hr }^{-1} \\
\end{array}$ & $\begin{array}{c}\text { CHAAP } \\
\text { Rate Constant, k } \\
\mathrm{hr}^{-1}\end{array}$ \\
\hline 1) Acetate & $\begin{array}{l}\text { A } \\
\text { B } \\
\text { C }\end{array}$ & $\begin{array}{l}0.256 \\
0.140 \\
0.447\end{array}$ & $\begin{array}{l}0.163 \\
0.111 \\
0.118\end{array}$ \\
\hline 2) Ethanol & $\begin{array}{l}\text { A } \\
\text { B } \\
\text { C }\end{array}$ & $\begin{array}{l}\mathrm{NC} \\
\mathrm{NC} \\
\mathrm{NC}\end{array}$ & $\begin{array}{c}1.484 \\
\mathrm{NC} \\
1.373\end{array}$ \\
\hline 3) Starch & $\begin{array}{l}\text { A } \\
\text { B } \\
\text { C }\end{array}$ & $\begin{array}{l}0.114 \\
0.433 \\
\text { NC }\end{array}$ & $\begin{array}{l}0.124 \\
0.153 \\
0.450\end{array}$ \\
\hline $\begin{array}{l}\text { 4) Acetate+ } \\
\text { Ammonium }\end{array}$ & $\begin{array}{l}\text { A } \\
\text { B } \\
\text { C }\end{array}$ & $\begin{array}{l}0.120 \\
0.267 \\
0.336\end{array}$ & $\begin{array}{l}0.167 \\
0.168 \\
0.408\end{array}$ \\
\hline 5). Control & $\begin{array}{l}\text { A } \\
\text { B } \\
\text { C }\end{array}$ & $\begin{array}{l}0.175 \\
0.055 \\
0.137 \\
\end{array}$ & $\begin{array}{l}0.088 \\
0.036 \\
0.114 \\
\end{array}$ \\
\hline
\end{tabular}

Of the three carbon sources tested, ethanol had a very significant ( 95 percent confidence) effect in enhancing the reductive biotransformation of RDX. The rate of removal was so fast that there was not enough resolution to calculate the RDX rate kinetics in groundwater amended with ethanol. This observation was more pronounced in NOP groundwater. Figure 14 shows a typical bed profile of RDX concentration in NOP aquifer material in Column Set \#1, amended with acetate as an electron donor. RDX removal rates in ethanol-amended columns 


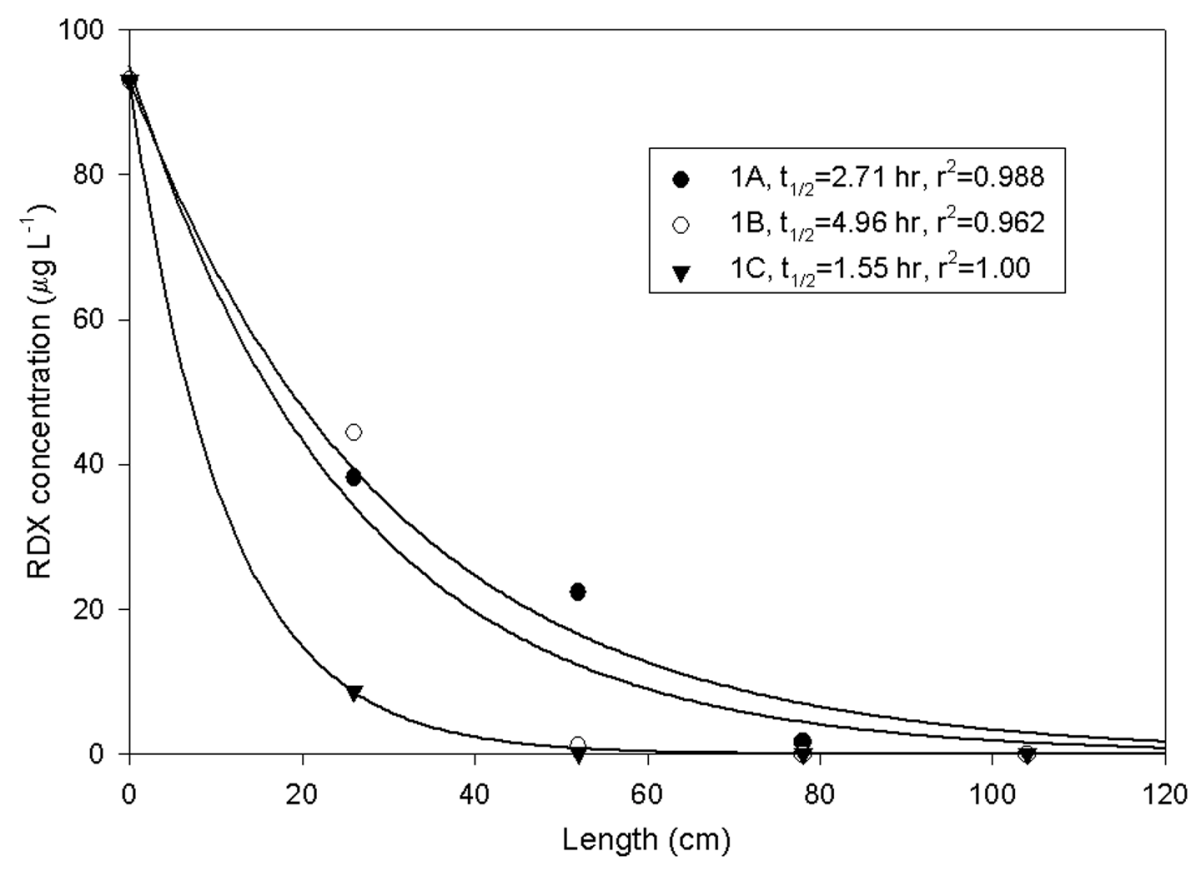

Figure 14. RDX biodegradation kinetics in NOP aquifer material (Column Set \#1)

for both sites were significantly ( 95 percent confidence) different than other columns amended with acetate and soluble starch. Removal rates were similar in Column Set \#1 and \#4 where groundwater was amended with acetate as carbon source. The addition of ammonium in Column Set \#4 did not have a synergistic effect on the enhancement of RDX degradation. These findings are contrary to the beneficial effects of ammonium on TNT biodegradation, reported by Funk et al. (1993), where TNT removal rates increased with increasing amounts of ammonium and $25 \mathrm{mM} \mathrm{NH}_{4} \mathrm{Cl}\left(1.33 \mathrm{~g} \mathrm{~L}^{-1}\right)$ were found optimal. However, these findings are in line with the results reported by Beller (2002) that ammonium (a favorable nitrogen source) had no beneficial effects on RDX degradation whereas nitrate (a favorable election sink) halted RDX consumption by aquifer microorganisms. In all other columns (except ethanol-amended column), the removal rates were not statistically significant ( 95 percent confidence), especially the Control column. During routine sampling (Appendix B, Figures B35 and B40), no RDX was seen in Control column effluent, with some occasional detectable levels of RDX. This was mainly because of the reduced conditions created by using helium in the pressure reservoir that reduced the partial pressure of oxygen in groundwater. So in actuality, these Control columns were not positive control but only the amendment (electron donor) control. However, the inlet sections in these columns were not as reduced as the outlet sections that resulted in relatively lower removal rates along the bed profile (Figures B45 and B50). 


\section{Groundwater Toxicity}

Groundwater toxicity analysis was performed on influent and effluent streams from each individual column. Microtox ${ }^{\circledR}$ analysis was employed for this purpose. Results of Microtox ${ }^{\circledR}$ analyses on column influent and effluent are summarized in Table 10. Out of the three carbon sources used, ethanol showed acute toxic effects in influent as well as effluent streams. Most prominently toxic effects were observed in effluent stream, probably because of conversion of ethanol to some intermediate transformation product(s) that are toxic to the test organism used in Microtox ${ }^{\circledR}$. Presence of acetate in groundwater showed no acute toxicity; however, addition of soluble starch exhibited toxicity in the influent stream that was removed in the aquifer material.

\begin{tabular}{|c|c|c|c|c|c|c|c|c|c|}
\hline \multicolumn{10}{|c|}{\begin{tabular}{||l} 
Table 10 \\
Toxicity Levels of Influent and Effluent from Each Column \\
\end{tabular}} \\
\hline \multirow[b]{3}{*}{ Column Tag } & \multirow{3}{*}{$\begin{array}{l}\text { Inlet/ } \\
\text { Outlet }\end{array}$} & \multicolumn{4}{|c|}{ NOP } & \multicolumn{4}{|c|}{ CHAAP } \\
\hline & & \multicolumn{2}{|c|}{$\begin{array}{l}\text { 5-min } \\
\text { Toxicity }\end{array}$} & \multicolumn{2}{|c|}{$\begin{array}{l}\text { 15-min } \\
\text { Toxicity }\end{array}$} & \multicolumn{2}{|c|}{$\begin{array}{c}\text { 5-min } \\
\text { Toxicity }\end{array}$} & \multicolumn{2}{|c|}{$\begin{array}{l}\text { 15-min } \\
\text { Toxicity }\end{array}$} \\
\hline & & $\mathrm{EC}_{50}$ & $r^{2}$ & $\mathrm{EC}_{50}$ & $r^{2}$ & $\mathrm{EC}_{50}$ & $r^{2}$ & $\mathrm{EC}_{50}$ & $r^{2}$ \\
\hline 1) Acetate & $\begin{array}{l}\text { Inlet-Tank } \\
\text { Outlet-A } \\
\text { Outlet-B } \\
\text { Outlet-C } \\
\end{array}$ & $\begin{array}{l}\mathrm{NC} \\
\mathrm{NC} \\
\mathrm{NC} \\
\mathrm{NC}\end{array}$ & $\begin{array}{l}\text { NC } \\
\text { NC } \\
\text { NC } \\
\text { NC }\end{array}$ & $\begin{array}{l}\text { NC } \\
\text { NC } \\
\text { NC } \\
\text { NC }\end{array}$ & $\begin{array}{l}\mathrm{NC} \\
\mathrm{NC} \\
\mathrm{NC} \\
\mathrm{NC}\end{array}$ & $\begin{array}{l}\text { NC } \\
\text { NC } \\
\text { NC } \\
\text { NC }\end{array}$ & $\begin{array}{l}\mathrm{NC} \\
\mathrm{NC} \\
\mathrm{NC} \\
\mathrm{NC}\end{array}$ & $\begin{array}{l}\text { NC } \\
N C \\
N C \\
N C \\
\end{array}$ & $\begin{array}{l}\mathrm{NC} \\
\mathrm{NC} \\
\mathrm{NC} \\
\mathrm{NC} \\
\end{array}$ \\
\hline 2) Ethanol & $\begin{array}{l}\text { Inlet-Tank } \\
\text { Outlet-A } \\
\text { Outlet-B } \\
\text { Outlet-C } \\
\end{array}$ & $\begin{array}{l}\mathrm{NC} \\
9.58 \\
7.11 \\
7.11 \\
\end{array}$ & $\begin{array}{l}\mathrm{NC} \\
0.99 \\
0.89 \\
0.98 \\
\end{array}$ & $\begin{array}{l}\mathrm{NC} \\
9.32 \\
7.43 \\
7.24 \\
\end{array}$ & $\begin{array}{l}\mathrm{NC} \\
0.99 \\
0.96 \\
0.98 \\
\end{array}$ & $\begin{array}{c}\mathrm{NC} \\
4.94 \\
5.68 \\
13.09 \\
\end{array}$ & $\begin{array}{l}\mathrm{NC} \\
0.97 \\
0.99 \\
0.58 \\
\end{array}$ & $\begin{array}{c}43.23 \\
3.99 \\
4.36 \\
7.41 \\
\end{array}$ & $\begin{array}{l}0.89 \\
0.94 \\
0.97 \\
0.99 \\
\end{array}$ \\
\hline 3) Starch & $\begin{array}{l}\text { Inlet-Tank } \\
\text { Outlet-A } \\
\text { Outlet-B } \\
\text { Outlet-C } \\
\end{array}$ & $\begin{array}{c}24.96 \\
\text { NC } \\
36.78 \\
\text { NC } \\
\end{array}$ & $\begin{array}{c}0.94 \\
\text { NC } \\
0.96 \\
\text { NC }\end{array}$ & $\begin{array}{c}13.69 \\
\text { NC } \\
29.24 \\
\text { NC } \\
\end{array}$ & $\begin{array}{l}0.96 \\
N C \\
0.96 \\
N C \\
\end{array}$ & $\begin{array}{c}77.43 \\
\text { NC } \\
\text { NC } \\
41.80 \\
\end{array}$ & $\begin{array}{l}0.98 \\
\text { NC } \\
\text { NC } \\
0.87 \\
\end{array}$ & $\begin{array}{c}52.65 \\
\text { NC } \\
\text { NC } \\
41.31 \\
\end{array}$ & $\begin{array}{l}0.98 \\
\mathrm{NC} \\
\mathrm{NC} \\
0.95 \\
\end{array}$ \\
\hline $\begin{array}{l}\text { 4) Acetate+ } \\
\text { Ammonium }\end{array}$ & $\begin{array}{l}\text { Inlet-Tank } \\
\text { Outlet-A } \\
\text { Outlet-B } \\
\text { Outlet-C } \\
\end{array}$ & $\begin{array}{l}\mathrm{NC} \\
\mathrm{NC} \\
\mathrm{NC} \\
\mathrm{NC}\end{array}$ & $\begin{array}{l}\text { NC } \\
\text { NC } \\
\text { NC } \\
\text { NC }\end{array}$ & $\begin{array}{c}\mathrm{NC} \\
24.24 \\
\mathrm{NC} \\
78.59 \\
\end{array}$ & $\begin{array}{l}\mathrm{NC} \\
0.96 \\
\mathrm{NC} \\
0.98 \\
\end{array}$ & $\begin{array}{l}\mathrm{NC} \\
\mathrm{NC} \\
\mathrm{NC} \\
\mathrm{NC}\end{array}$ & $\begin{array}{l}\mathrm{NC} \\
\mathrm{NC} \\
\mathrm{NC} \\
\mathrm{NC} \\
\end{array}$ & $\begin{array}{c}\mathrm{NC} \\
\mathrm{NC} \\
52.28 \\
\mathrm{NC}\end{array}$ & $\begin{array}{l}\mathrm{NC} \\
\mathrm{NC} \\
0.96 \\
\mathrm{NC} \\
\end{array}$ \\
\hline 5) Control & $\begin{array}{l}\text { Inlet-Tank } \\
\text { Outlet-A } \\
\text { Outlet-B } \\
\text { Outlet-C }\end{array}$ & $\begin{array}{c}\text { NC } \\
\text { NC } \\
84.54 \\
\text { NC }\end{array}$ & $\begin{array}{l}\text { NC } \\
\text { NC } \\
0.93 \\
\text { NC }\end{array}$ & $\begin{array}{c}\text { NC } \\
64.06 \\
N C \\
N C\end{array}$ & $\begin{array}{l}\mathrm{NC} \\
0.92 \\
\mathrm{NC} \\
\mathrm{NC}\end{array}$ & $\begin{array}{l}\mathrm{NC} \\
\mathrm{NC} \\
\mathrm{NC} \\
\mathrm{NC}\end{array}$ & $\begin{array}{l}\mathrm{NC} \\
\mathrm{NC} \\
\mathrm{NC} \\
\mathrm{NC}\end{array}$ & $\begin{array}{l}\mathrm{NC} \\
\mathrm{NC} \\
\mathrm{NC} \\
\mathrm{NC}\end{array}$ & $\begin{array}{l}\mathrm{NC} \\
\mathrm{NC} \\
\mathrm{NC} \\
\mathrm{NC}\end{array}$ \\
\hline
\end{tabular}




\section{Conclusions}

A treatability study was performed to examine the feasibility of treating RDX-contaminated groundwater by adding organic carbon as a source for inducing biological activity in situ at the former NOP or CHAAP. These two sites were selected through an objective screening and selection process that examined 10 sites from across the United States. This treatability study examined the use of four amendments (acetate, ethanol, soluble starch, and acetate plus ammonium).

The treatability study shows that the bioremediation of RDX in situ can be achieved by inducing a reductive environment at the two sites studied. Based upon the location of the two sites and the infrastructure present at the two sites, the NOP site was selected for the field demonstration portion of the project.

All the amendments studied were able to achieve the necessary reducing conditions for removal of RDX contamination. The addition of some amendments resulted in increased toxicity based on Microtox analysis. Ethanol addition itself did not result in increased toxicity, but biological activity in this system did induce high toxicity. The addition of soluble starch resulted in increased toxicity that was removed by biological activity. Based on the results mentioned above the addition of these amendments will not be attempted in the field demonstration/validation. Acetate will be used in the field evaluation. The addition of ammonium as a nitrogen source did not significantly increase the removal rate of RDX and, therefore, will not be used in the field demonstration. A detailed description of the field study will incorporate the results presented here and will follow in the Demonstration/Validation Plan. 


\section{References}

Akhavan, J. (1998). The Chemistry of Explosives. Royal Society of Chemistry, Cambridge, UK.

ATSDR. (1996). RDX Fact Sheet (online), available from URL

http://www.atsdr.cdc.gov/tfacts78.html (accessed July 10, 2002).

Beller, H. R. (2002) "Anaerobic biotransformation of RDX (hexahydro-1,3,5trinitro-1,3,5-triazine) by aquifer bacteria using hydrogen as the sole electron donor," Water Res. 36, 2533-2540.

Binks, P. R., Nicklin, S., and Bruce, N. C. (1995). "Degradation of hexahydro1,3,5-trinitro-1,3,5-triazine (RDX) by Stenotrophomonas maltophilia PB1," Appl. Environ. Microbiol. 61, 1318-1322.

Cataldo, D. A., Harvey, S. D., and Fellows, R. J. (1990). "An evaluation of the environmental fate and behavior of munitions material (TNT, RDX) in soil and plant systems. Environmental fate and behavior of RDX. PNL-7529; ADA223540," U.S. Army Biomedical Research and Development Laboratory, Fort Detrick, MD.

Coleman, N. V., Nelson, D. R., and Duxbury, T. (1998). “Aerobic biodegradation of hexahydro-1,3,5-trinitro-1,3,5-triazine (RDX) as a nitrogen source by a Rhodococcus sp. strain DN22," Soil Biol. Biochem. 30, 11591167.

Davis, J., Hansen, L., and O’Neal, B. (2001). "The effect of ubiquitous electron acceptors on the initiation of RDX biodegradation," Sixth International In Situ and On Site Bioremediation Symposium. 6(3), 43-49. Battelle Press, Columbus, $\mathrm{OH}$.

Defense Environmental Network and Information Exchange (DENIX). (2001). "Enhanced alternative and in situ treatment technologies for explosives in groundwater," available from URL http://www.denix.osd.mil/denix/DOD/Policy/Army/Aerta/Report/a12a.html. (accessed August 14, 2002).

Driver, C. J., and Fellows, R. J. (2000). "Bioavailability and metabolic partitioning of RDX in voles fed plant material grown in contaminated soil," Pacific Northwest National Laboratory, Richland, WA.

Etiner, E. L. (1989). "Water quality criteria for hexahydro-1,3,5-trinitro-1,3,5triazine (RDX)," Regulatory Toxicol. Pharmacol. 9, 147-157. 
Fellows, R. J., Harvey, S. D., and Cataldo, D. A. (1995). "Evaluation of the metabolic fate of munitions material (TNT \& RDX) in plant systems and initial assessment of material interaction with plant genetic material. Validation of the metabolic fate of munitions material (TNT \& RDX) in mature crops," PNL-10825. U.S. Army Biomedical Research and Development Laboratory, Fort Detrick, Fredrick, MD.

Fernando, T., and Aust, S. D. (1991). "Biodegradation of munition waste, TNT (2,4,6, trinitrotoluene) and RDX (hexahydro-1,3,5-trinitro-1,3,5-triazine)," Emerging Technologies in Hazardous Waste Management (D.W. Tedder and F.G. Pohland, ed.), American Chemical Society, Washington, DC., 214-231.

Freedman, D. L., and Sutherland, K. W. (1998). "Biodegradation of hexahydro1,3,5-trinitro-1,3,5-triazine (RDX) under nitrate-reducing conditions," Wat. Sci. Tech. 38, 33-40.

Funk, S. B., Roberts, D. J., Crawford, D. L., and Crawford, R. L. (1993). "Initial-phase optimization for bioremediation of munition compoundcontaminated soils," Appl. Environ. Microbiol. 59, 2171-2177.

Graff, T. (2001). Personal Communication, U.S. Army Corps of Engineers, (CENWK-PM-ES), Nebraska Ordinance Plant, Nebraska.

Halasz, A., Spain, J., Paquet, L., Beaulieu, C., and Hawari, J. (2002). " Insights into the formation and degradation mechanisms of methylenedinitramine during the incubation of RDX with anaerobic sludge," Environ. Sci. Technol. $36,633-638$.

Hansen, L. D., and Davis, J. L. (2001). "Biologically active zone enhancement (BAZE) for in situ RDX degradation in groundwater (ESTCP\#00110)Treatability study plan," U.S. Army Engineer Research and Development Center, Vicksburg, MS.

Harvey, S. D., Fellows, R. J., Cataldo, D. A., and Bean, R. M. (1991). "Fate of the explosive hexahydro-1,3,5-trinitro-1,3,5-triazine (RDX) in soil and bioaccumulation in bush bean hydrophonic plants," Env. Toxic. \& Chem. 10, 845- 855 .

Hawari, J., Halasz, A., Sheremata, T., Beaudet, S., Groom, C., Paquet, L., Rhofir, C., Ampleman, G., and Thiboutot, S. (2000). "Characterization of metabolites during biodegradation of hexahydro-1,3,5-trinitro-1,3,5-triazine (RDX) with municipal anaerobic sludge," Appl. Environ. Microbiol. $66,2652-2657$.

Headquarters, Department of the Army. (1994). "Military Explosives," TM 91300-214, Washington, DC.

Hoffsommer, J. C., and Rosen, J. M. (1973). "Hydrolysis of explosives in sea water," Bull. Environ. Contamin. \& Toxic. 10, 78-79.

Larson, S. L., Jones, R. P, Escalon, L., and Parker, D. (1999). "Classification of explosives transformation products in plant tissue," Env. Tox and Chem. $18,1270-1276$.

Major, M. A., Johnson, M. S., and Salice, C. J. (2002). "Bioconcentration, bioaccumulation and biomagnification of nitroaromatic and nitramine explosives and their metabolites and environmental breakdown products," 
US Army Center for Health Promotion and Preventive Medicine, Aberdeen Proving Ground, Maryland.

McCormick, N. G., Cornell, J. H., and Kaplan, A. M. (1981). "Biodegradation of hexahydro-1,3,5-trinitro-1,3,5-triazine," Appl. Environ. Microbiol. $42,817-823$.

. (1985). "The anaerobic biotransformation of RDX, HMX and their acetylated derivatives," Technical Report No.85-007, U.S. Army Natick Research, Development, and Engineering Center.

Pennington, J. C. (1999). "Explosives," Environmental availability in soils: Chlorinated organics, explosives, metals, W. C. Anderson, R. C. Loehr, B. P. Smith, ed., Am. Acad. Environ. Eng. NY, 85-109.

Pitot, H.C. III, and Dragan, Y.P. (1996). "Chemical carcinogens," Toxicology. C. D. Klaassen, and J. Doull, ed., $5^{\text {th }}$ ed., McGraw-Hill, NY, 201-267.

Preub, A., and Rieger, P-G. (1995). "Anaerobic transformation of 2,4,6Trinitrotoluene and other nitroaromatic compounds," Biodegradation of nitroaromatic compounds. J. C. Spain, ed., Plenum Press, NY, 69-85.

Sheremata, T. W., and Hawari, J. (2000). "Biodegradation of RDX by the white rot fungus Phanerochaete chrysosporium to carbon dioxide and nitrous oxide," Environ. Sci Technol. 34, 3384-3388.

Sheremata, T.W., Halasz, A., Paquet, L., Thiboutot, S., Ampleman, G., and Hawari, J. (2001). "The fate of the cyclic nitramine explosive RDX in natural soil," Environ. Sci. Technol. 35, 1037-1040.

Sikka, H. C., Banerjee, S., Pack, E. J., and Appleton, H. T. (1980). "Environmental fate of RDX and TNT," Technical Report 81-538, U.S. Army Medical Research and Development Command, Fort Detrick, Frederick, MD.

Singh, J., Comfort, S. D., Hundal, L. S., and Shea, P. J. (1998). "Long-term RDX sorption and fate in soil," J. Environ. Qual. 27, 572-577.

Spanggord, R. J., Mill, T., Chou, T.W., Mabey, W.R., Smith, J.H., and Lee, S. (1980a). "Environmental fate studies on certain munition wastewater constituents, final report, phase I - Literature review," SRI Project No. LSU-7934, SRI International, Menlo Park, CA.

. (1980b). "Environmental fate studies on certain munition wastewater constituents, final report, phase II - Laboratory studies," SRI Project No. LSU-7934, SRI International, Menlo Park, CA.

URSGWC (URS Greiner Woodward Clyde). (1999). “Annual sampling event for the LTM program - Final report," Cornhusker Army Ammunition Plant, Omaha, NE.

. (2000). "1999-2000 groundwater monitoring program annual report Operable unit no.2," Former Nebraska Ordnance Plant, Kansas City, MO.

. (2001). "BAZE sampling plan," Former Nebraska Ordinance Plant, Meade, NE. 
U.S. Environmental Protection Agency. (2000). "Drinking Water Standards and Health Advisories," EPA 822-b-00-001, Office of Water, Washington, DC.

VanderLoop, S. L., Suidan, M. T., Berchtold, S. R., Moteleb, M. A., and Maloney, S. W. (1997). "Effects of molecular oxygen on GAC adsorption of energetics," Wat. Sci. Tech. 35, 197-204.

Walker, J. E., and Kaplan, D. L. (1992). "Biological degradation of explosives and chemical agents," Biodegradation 3, 369-385. 


\section{Appendix A Site Screening Process}




\begin{tabular}{|c|c|c|c|c|}
\hline Site & $\begin{array}{l}\text { Project Manager (PM) } \\
\text { Support } \\
\text { Yes/No }\end{array}$ & $\begin{array}{l}\text { RDX } \\
\text { Contamination } \\
>20 \mu \mathrm{g} \mathrm{L}^{-1} \\
<20 \mu \mathrm{g} \mathrm{L}^{-1}\end{array}$ & $\begin{array}{l}\text { Contamination Depth } \\
<100 \mathrm{ft},>100 \mathrm{ft}\end{array}$ & $\begin{array}{l}\text { Plume Characterized } \\
\text { Yes/No }\end{array}$ \\
\hline $\begin{array}{l}\text { Nebraska } \\
\text { Ordnance Plant, } \\
\text { NE }\end{array}$ & $\begin{array}{l}\text { Tom Graf, NWK, 816-983- } \\
\text { 3351. PM supports and } \\
\text { Regulators have been } \\
\text { contacted in regard to a } \\
\text { possible ESTCP Demo and } \\
\text { are receptive. There remains } \\
\text { about } \$ 3 \text { mil in contract } \\
\text { capacity with URS for this site. }\end{array}$ & $\begin{array}{l}400-500 \mu \mathrm{g} \mathrm{L}^{-1} . \\
\text { Large plume, } \\
3 \times 4 \text { miles. }\end{array}$ & $\begin{array}{l}\text { GW surface } 35 \mathrm{ft} . \\
\text { Bedrock } 100 \mathrm{ft} . \\
\text { Homogenous flow } \\
\text { gradient around } 2 \\
\text { ft/day. Direct-push } \\
\text { technologies have been } \\
\text { very effective at the } \\
\text { site. There are a lot of } \\
\text { well logs for OU } 2 .\end{array}$ & $\begin{array}{l}\text { Well Characterized. } \\
\text { First remediation is } \\
\text { focused on } \\
\text { containment with wells } \\
\text { on periphery of Plume. } \\
\text { Hot spot areas haven't } \\
\text { been addressed, } \\
\text { however, a } \\
\text { demonstration of } \\
\text { recirculation wells is } \\
\text { taking place. More } \\
\text { characterization work is } \\
\text { scheduled for this } \\
\text { summer in support of } \\
\text { the recirculation well } \\
\text { demonstration. }\end{array}$ \\
\hline $\begin{array}{l}\text { Cornhusker Army } \\
\text { Ammunition Plant, } \\
\text { NE }\end{array}$ & $\begin{array}{l}\text { Alvin Kam, NWO 402-221- } \\
7758 \\
\text { Ted Streckfuss } \\
402-221-3826 \text { Regulators and } \\
\text { PM are supportive of any } \\
\text { Demos. } \\
\text { Terry Thonen, URS Only } 1 \\
\text { year left on the contract; } \\
\text { however, they can utilize URS } \\
\text { through NWK contract. They } \\
\text { are currently responsible for } \\
\text { monitoring and modeling OU } 1 .\end{array}$ & $\begin{array}{l}35 \mu g \mathrm{~L}^{-1} \text { with hot } \\
\text { spots as high as } \\
2,000 \mu \mathrm{L} \mathrm{L}^{-1} \text {. }\end{array}$ & $\begin{array}{l}\text { Groundwater surface is } \\
10-15 \mathrm{ft} \text {. }\end{array}$ & $\begin{array}{l}\text { Well Characterized. } \\
\text { Very sandy aquifer. }\end{array}$ \\
\hline Ft. Meade, MD & $\begin{array}{l}\text { Russ Marsh, NAB } \\
\text { 410-962-2227 } \\
\text { PM, Regulators, and EPA } \\
\text { would support a demo. }\end{array}$ & $80-100 \mu \mathrm{g} \mathrm{L}^{-1}$ & $\begin{array}{l}\text { Groundwater depth } \\
\text { starts at less than } 10 \mathrm{ft} . \\
\text { Sandy aquifer, fast } \\
\text { moving, clay layer at } \\
200 \mathrm{ft} .\end{array}$ & $\begin{array}{l}\text { Very well characterized. } \\
\text { Presently pursuing a } \\
\text { NFA Closure. }\end{array}$ \\
\hline $\begin{array}{l}\text { Pueblo Army } \\
\text { Depot, CO }\end{array}$ & $\begin{array}{l}\text { Todd Wilson, NWO } \\
402-221-7750 \\
\text { PM and regulators would } \\
\text { support a demo. An } \\
\text { unsuccessful ChemOx demo } \\
\text { has been completed. } \\
\text { Presently there is going to } \\
\text { be an HRC demo on } 20-30 \mu g \\
\mathrm{~L}^{-1} \text {. Todd will send me the } \\
\text { Work Plan. }\end{array}$ & $\begin{array}{l}220 \mu g \mathrm{~L}^{-1}, \text { some } \\
\text { hits as high as } \\
10,000 \mu \mathrm{L} \mathrm{L}^{-1} \cdot 1 \\
\text { mile down gradient } \\
\text { at property } \\
\text { boundary there is } \\
1-2 \mu \mathrm{L} \mathrm{L}^{-1} \text {. }\end{array}$ & $\begin{array}{l}\text { Groundwater surface } \\
20 \mathrm{ft} . \\
\text { Bedrock } 40 \mathrm{ft} .\end{array}$ & $\begin{array}{l}\text { Well Characterized. } \\
\text { Old washout facility. }\end{array}$ \\
\hline $\begin{array}{l}\text { Louisiana Army } \\
\text { Ammunition Plant, } \\
\text { LA }\end{array}$ & $\begin{array}{l}\text { Doyle Williams, Env. Officer } \\
\text { 318-459-5108 } \\
\text { Customer and Regulators are } \\
\text { very supportive. WES (Danny } \\
\text { Harrelson 601-634-2685) is } \\
\text { currently doing some } \\
\text { continued monitoring to } \\
\text { document natural attenuation. } \\
\text { Presently Customer } \\
\text { Contracts on his own for the } \\
\text { limited RA which is taking } \\
\text { place under CERCLA. LAAP } \\
\text { is in "Caretaker" Status } \\
\text { indefinitely. }\end{array}$ & $\begin{array}{l}20 \text { to } 17,000 \mu \mathrm{L} \mathrm{L}^{-1} \text {. } \\
\text { In Area P because } \\
\text { of load lines and } \\
\text { test area. } \\
\text { Presently they are } \\
\text { considering } \\
\text { Groundwater as } \\
\text { one whole unit. }\end{array}$ & $\begin{array}{l}\text { Groundwater surface at } \\
30-35 \mathrm{ft} \text { below grade. } \\
\text { Sandy Loam aquifer. } \\
\text { Cain River Shale at } \\
300 \mathrm{ft} \text {. }\end{array}$ & $\begin{array}{l}\text { Real Well } \\
\text { Characterized. }\end{array}$ \\
\hline
\end{tabular}




\begin{tabular}{|c|c|c|c|c|}
\hline \multicolumn{5}{|c|}{ Table A1 (Concluded) } \\
\hline Site & $\begin{array}{l}\text { Project Manager (PM) } \\
\text { Support } \\
\text { Yes/No }\end{array}$ & $\begin{array}{l}\text { RDX Contamination } \\
>20 \mu \mathrm{g} \mathrm{L}^{-1} \\
<20 \mu \mathrm{g} \mathrm{L}^{-1}\end{array}$ & $\begin{array}{l}\text { Contamination Depth } \\
<100 \mathrm{ft},>100 \mathrm{ft}\end{array}$ & $\begin{array}{l}\text { Plume Characterized } \\
\text { Yes/No }\end{array}$ \\
\hline $\begin{array}{l}\text { Massachusetts } \\
\text { Military } \\
\text { Reservation, MA }\end{array}$ & $\begin{array}{l}\text { Phil Durgin, NAE } \\
978-318-8507, \\
\text { Site would be very } \\
\text { supportive of Innovative } \\
\text { Technology } \\
\text { Demonstrations. High } \\
\text { visibility site. }\end{array}$ & $\begin{array}{l}\text { One high hit of } 370 \mu \mathrm{g} \\
\mathrm{L}^{-1} \text { most other hits of } \\
100-150 \mu \mathrm{g} \mathrm{L}^{-1} \text {. }\end{array}$ & $\begin{array}{l}\text { Groundwater at } 100 \mathrm{ft} . \\
\text { Sandy Glacial Moraine } \\
\text { and Outwash. High } \\
\text { Hydraulic conductivity. } \\
\text { However, gradient is } \\
\text { low. Aerobic \& sandy } \\
\text { aquifer. May be difficult } \\
\text { for anaerobes. }\end{array}$ & $\begin{array}{l}\text { Well Characterized. } \\
\text { More than one plume. } \\
\text { Nothing has been } \\
\text { cleaned up yet. FS is } \\
\text { underway. }\end{array}$ \\
\hline $\begin{array}{l}\text { lowa Army } \\
\text { Ammunition Plant, } \\
\text { IA }\end{array}$ & $\begin{array}{l}\text { Kevin, Howe NWO } \\
\text { Ted Streckfuss } \\
402-221-3826 \\
\text { PM and regulators would } \\
\text { support a demo if this is an } \\
\text { appropriate site. }\end{array}$ & $\begin{array}{l}\text { Sporadic hits of RDX } \\
\text { along line } 800 .\end{array}$ & $8-10 \mathrm{ft}$ & $\begin{array}{l}\text { Groundwater not real } \\
\text { well characterized due } \\
\text { to tight soils, sporadic } \\
\text { hits of contamination, } \\
\text { slow aquifer flow } \\
\text { characteristics. }\end{array}$ \\
\hline $\begin{array}{l}\text { Umatilla Army } \\
\text { Depot, OR }\end{array}$ & $\begin{array}{l}\text { Kira Lynch, NWS } \\
\text { 206-764-6918. PM and } \\
\text { regulators would support a } \\
\text { demo. This would be a } \\
\text { timely demo, because } \\
\text { consideration is being given } \\
\text { to shutting down the } \\
\text { groundwater treatment } \\
\text { system and allow in situ } \\
\text { processes to take over if it } \\
\text { could be proven. Also } \\
\text { Camp Bonneville may be a } \\
\text { future site. Preliminary } \\
\text { sampling in one well (of } \\
\text { two) indicated } 44 \text { Mg L }{ }^{-1} \\
\text { RDX. }\end{array}$ & $\begin{array}{l}\text { RDX concentra-tions } \\
\text { initially started out } \\
\text { about } 2400 \mu \mathrm{g} \mathrm{L}^{-1} \text {, } \\
\text { however the } \\
\text { groundwater treatment } \\
\text { system has reduced } \\
\text { those considerably (15- } \\
20 \mu \mathrm{L}^{-1} \text { ). Only a small } \\
\text { portion of the plume } \\
\text { has concentrations } \\
\text { above } 290 \mu \mathrm{L}^{-1} \text { and } \\
\text { this appears that it will } \\
\text { be flushed through the } \\
\text { treatment plant. }\end{array}$ & $\begin{array}{l}\text { Groundwater is } \\
\text { between } 70-120 \mathrm{ft} \\
\text { below ground surface. } \\
\text { Sand Aquifer and the } \\
\text { gradient varies } \\
\text { seasonally. } \\
\text { Groundwater treatment } \\
\text { plant is processing } \\
1300 \mathrm{gpm} .\end{array}$ & $\begin{array}{l}\text { Well Characterized } \\
\text { Site. } \\
\text { Other ESTCP efforts } \\
\text { are taking place at the } \\
\text { site. } \\
\text { EPA/TIO and USACE } \\
\text { are evaluating Pump } \\
\& \text { Treat Optimization. } \\
\text { ERDC (Flemming) } \\
\text { /Oregon Research } \\
\text { Institute are } \\
\text { evaluating ZVI for } \\
\text { explosives. }\end{array}$ \\
\hline Tooele, UT & $\begin{array}{l}\text { Brad Call, SAS } \\
\text { 916-557-6649. Not sure } \\
\text { about PM, Customer and } \\
\text { Regulator Support }\end{array}$ & $\begin{array}{l}\text { Low, } 15.2 \mu \mathrm{g} \mathrm{L}^{-1} \text {. } \\
\text { Originates from shell \& } \\
\text { projectile demil } \\
\text { washout facility. } \\
\text { Recycled explosives } \\
\text { and discharged to } \\
\text { ponds. }\end{array}$ & $\begin{array}{l}\text { Groundwater depth } \\
200-300 \mathrm{ft} . \text { Lake } \\
\text { Bonneville Sediments. } \\
100 \text { s of feet of various } \\
\text { layers Heterogeneous } \\
\text { stratification, Moderate } \\
\text { to high permeability }\end{array}$ & $\begin{array}{l}\text { Relatively well } \\
\text { characterized. (Only } \\
6-10 \text { wells) Biggest } \\
\text { concern has be soils. }\end{array}$ \\
\hline $\begin{array}{l}\text { Picatinny Arsenal, } \\
\text { NJ }\end{array}$ & $\begin{array}{l}\text { Russ Marsh, NAB } \\
410-962-2227 \text {. Wasn't sure } \\
\text { whether this would be a } \\
\text { good site or not. }\end{array}$ & Not available. & Not available & \\
\hline
\end{tabular}




\begin{tabular}{|c|c|c|c|c|}
\hline \multicolumn{5}{|c|}{$\begin{array}{l}\text { Table A2 } \\
\text { Selection Criteria Data from Selected Five Sites }\end{array}$} \\
\hline Site & $\begin{array}{l}\text { RDX } \\
\text { Concentration }\end{array}$ & $\begin{array}{l}\text { Hydrogeologic Data: } \\
\text { Groundwater velocity, } \\
\text { Hydraulic } \\
\text { Conductivity } \\
\end{array}$ & $\begin{array}{l}\text { Geochemical Data: } \\
\text { D.O., } \\
\text { Nitrate, } \\
\text { Sulfate, } \\
\text { Organic Carbon, } \\
\text { pH, } \\
\text { Bicarbonate, } \\
\text { Alkalinity } \\
\end{array}$ & $\begin{array}{l}\text { Infrastructure: } \\
\text { Leverage Funding, } \\
\text { Electricity, } \\
\text { Water, } \\
\text { Monitoring Wells } \\
\end{array}$ \\
\hline $\begin{array}{l}\text { Nebraska } \\
\text { Ordnance } \\
\text { Plant }\end{array}$ & "MW 5B $220 \mu \mathrm{g} \mathrm{L}^{-1}$ & $\begin{array}{l}\text { Hydraulic Conductivity: } \\
50-160 \mathrm{ft} \mathrm{d}^{-1} \\
\text { Groundwater velocity } \\
2 \mathrm{ft} \mathrm{d}^{-1}\end{array}$ & $\begin{array}{l}\text { D.O varies } 0-10 \mathrm{mg} \mathrm{L}^{-1} \\
\text { Nitrate: } 6.3-7.9 \mathrm{mg} \mathrm{L}^{-1} \\
\text { Sulfate: } 39-110 \mathrm{mg} \mathrm{L}^{-1} \\
\text { Organic Carbon: } 1.5-2.81 \\
\mathrm{mg} \mathrm{L} \mathrm{L}^{-1} \\
\text { PH: } 6.6-7.3 \\
\text { Bicarbonate Alkalinity: } 170- \\
190 \mathrm{mg} \mathrm{L}^{-1}\end{array}$ & $\begin{array}{l}\text { More than } 160 \text { monitoring } \\
\text { wells on site. Will facilitate } \\
\text { access, coordinate sampling } \\
\text { events, etc... }\end{array}$ \\
\hline $\begin{array}{l}\text { Cornhusker } \\
\text { Army } \\
\text { Ammunition } \\
\text { Plant }\end{array}$ & $\begin{array}{l}35 \mu \mathrm{L} \mathrm{L}^{-1} \text { with hot } \\
\text { spots as high as } \\
2,000 \mathrm{ppb}\end{array}$ & No data & No data & No data \\
\hline $\begin{array}{l}\text { Pueblo } \\
\text { Army Depot }\end{array}$ & $23-55 \mu \mathrm{g} \mathrm{L}^{-1}$. & $\begin{array}{l}\text { Hydraulic Conductivity: } \\
28 \mathrm{ft} \mathrm{d}^{-1} \\
\text { Groundwater velocity } \\
6.5 \mathrm{ft} \mathrm{d}^{-1}\end{array}$ & $\begin{array}{l}\text { D.O: } 12.4-20 \mathrm{mg} \mathrm{L}^{-1} \\
\text { Nitrate: } 18-80 \mathrm{mg} \mathrm{L}^{-1} \\
\text { Sulfate: } 77-480 \mathrm{mg} \mathrm{L}^{-1} \\
\text { Organic Carbon: no data } \\
\text { PH: } 7-7.6 \\
\text { Bicarbonate Alkalinity: } 160- \\
265 \mathrm{mg} \mathrm{L}^{-1}\end{array}$ & $\begin{array}{l}\text { Leverage "In Kind services" } \\
\text { on-site lab, samplers, etc. } \\
\text { Many wells currently in place. } \\
\text { GW Flux } 3.6 \mathrm{gpm} \\
\text { Hydraulic Grad. } 0.007 \mathrm{ft} \text { per ft. } \\
\text { Salinity } 0.03-0.15 \%\end{array}$ \\
\hline $\begin{array}{l}\text { Louisiana } \\
\text { Army } \\
\text { Ammunition } \\
\text { Plant }\end{array}$ & 20 to $17,000 \mu \mathrm{g} \mathrm{L}^{-1}$. & No data & No data & No data \\
\hline Ft. Meade & $4-120 \mu \mathrm{g} \mathrm{L}^{-1}$. & $\begin{array}{l}\text { Hydraulic Conductivity: } \\
1-5 \mathrm{ft} \mathrm{d}^{-1} \\
\text { Groundwater velocity: } \\
0.08 \mathrm{ft} \mathrm{d}^{-1}\end{array}$ & $\begin{array}{l}\text { D.O: } 4-7 \mathrm{mg} \mathrm{L}^{-1} \\
\text { Nitrate: no data } \\
\text { Sulfate: no data } \\
\text { Organic Carbon: no data } \\
\mathrm{PH}: 4.3-6 \text { one at } 9 \\
\text { Bicarbonate Alkalinity: no } \\
\text { data }\end{array}$ & $\begin{array}{l}\text { Funding uncertain, probably } \\
\text { limited. Wells are in place and } \\
\text { available }\end{array}$ \\
\hline
\end{tabular}




\section{Appendix B Plots of Results for Individual Columns}




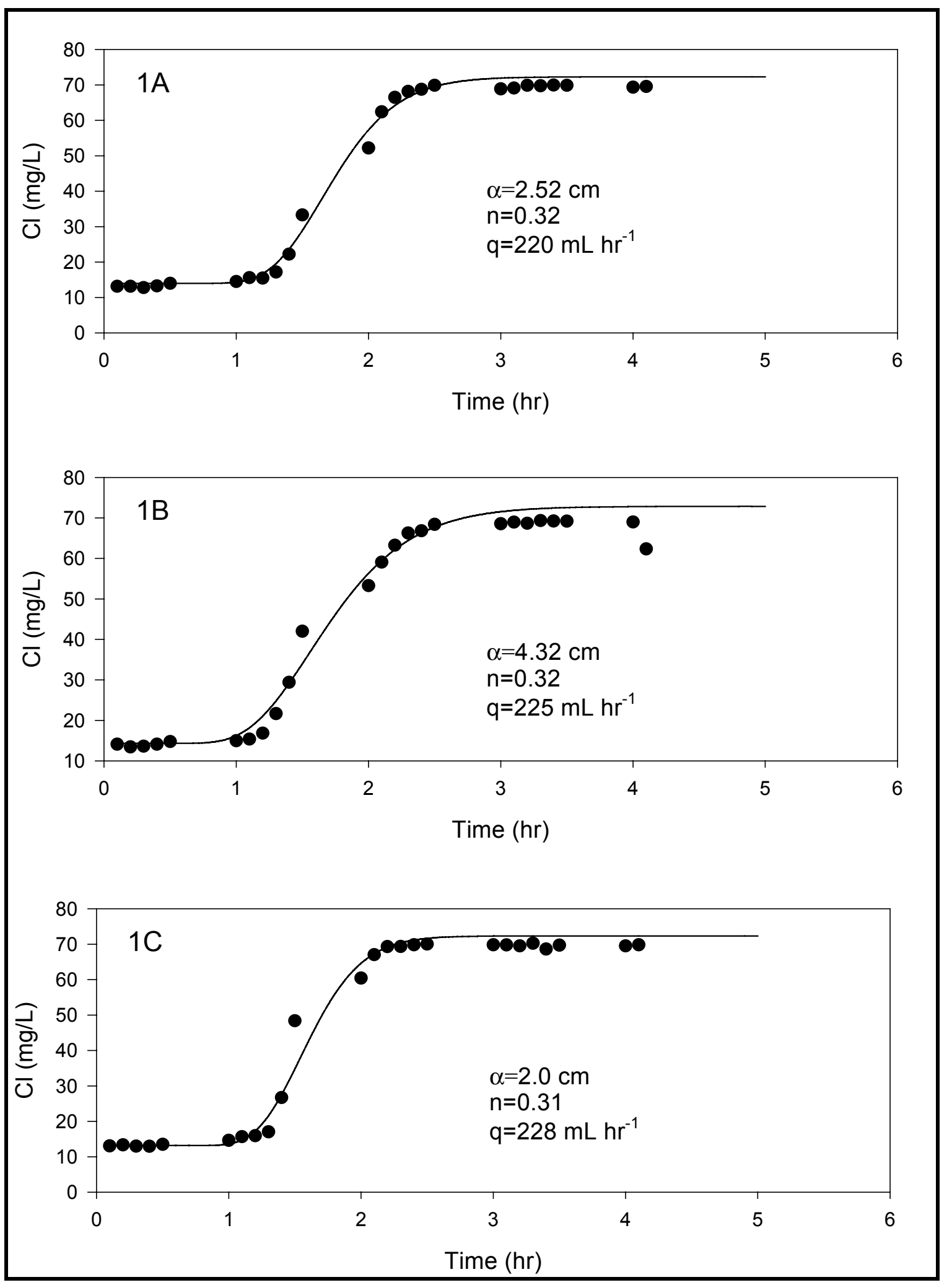

Figure B1. Chloride tracer breakthrough curve for NOP Column Set \#1 


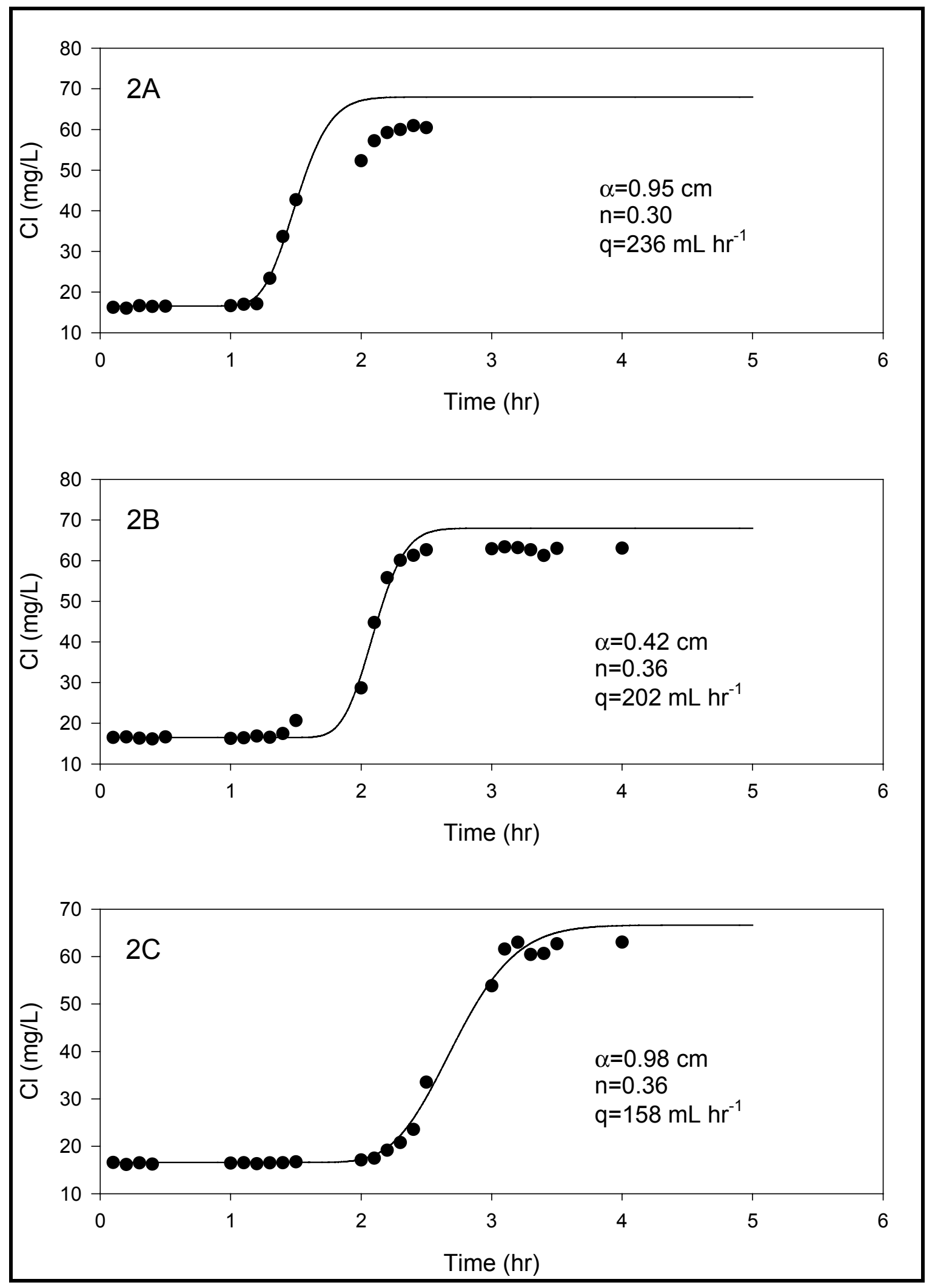

Figure B2. Chloride tracer breakthrough curve for NOP Column Set \#2 


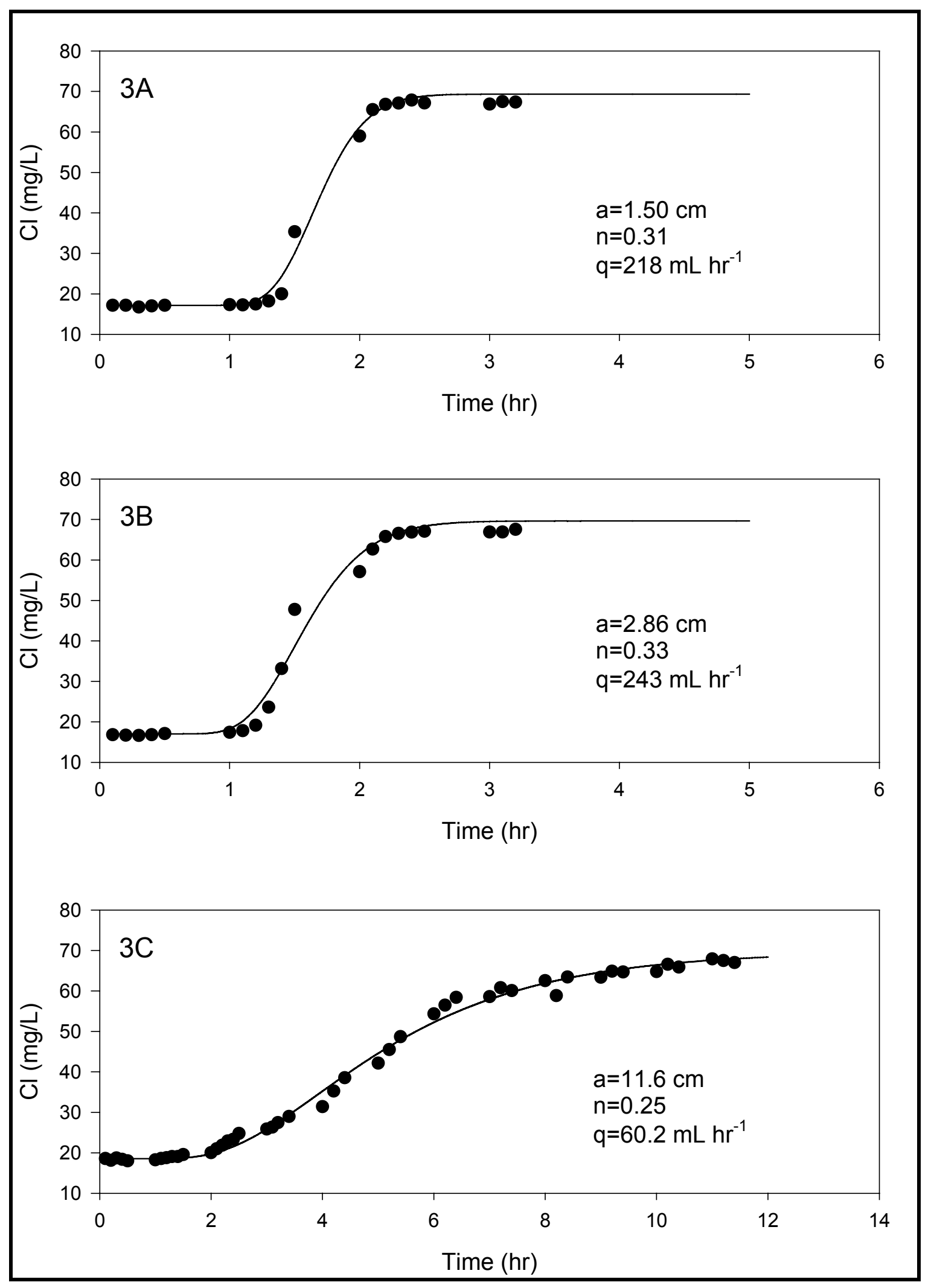

Figure B3. Chloride tracer breakthrough curve for NOP Column Set \#3 


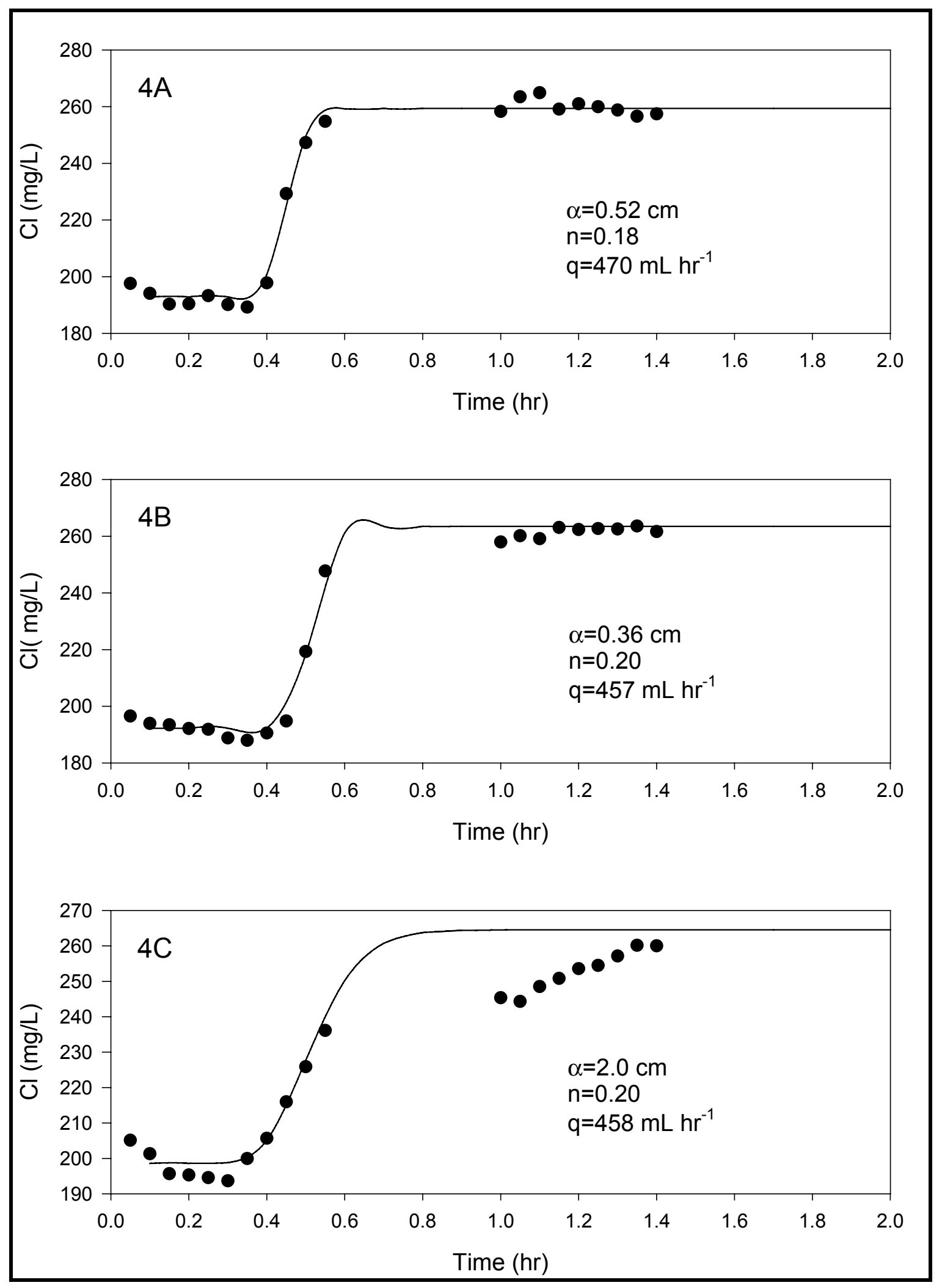

Figure B4. Chloride tracer breakthrough curve for NOP Column Set \#4 


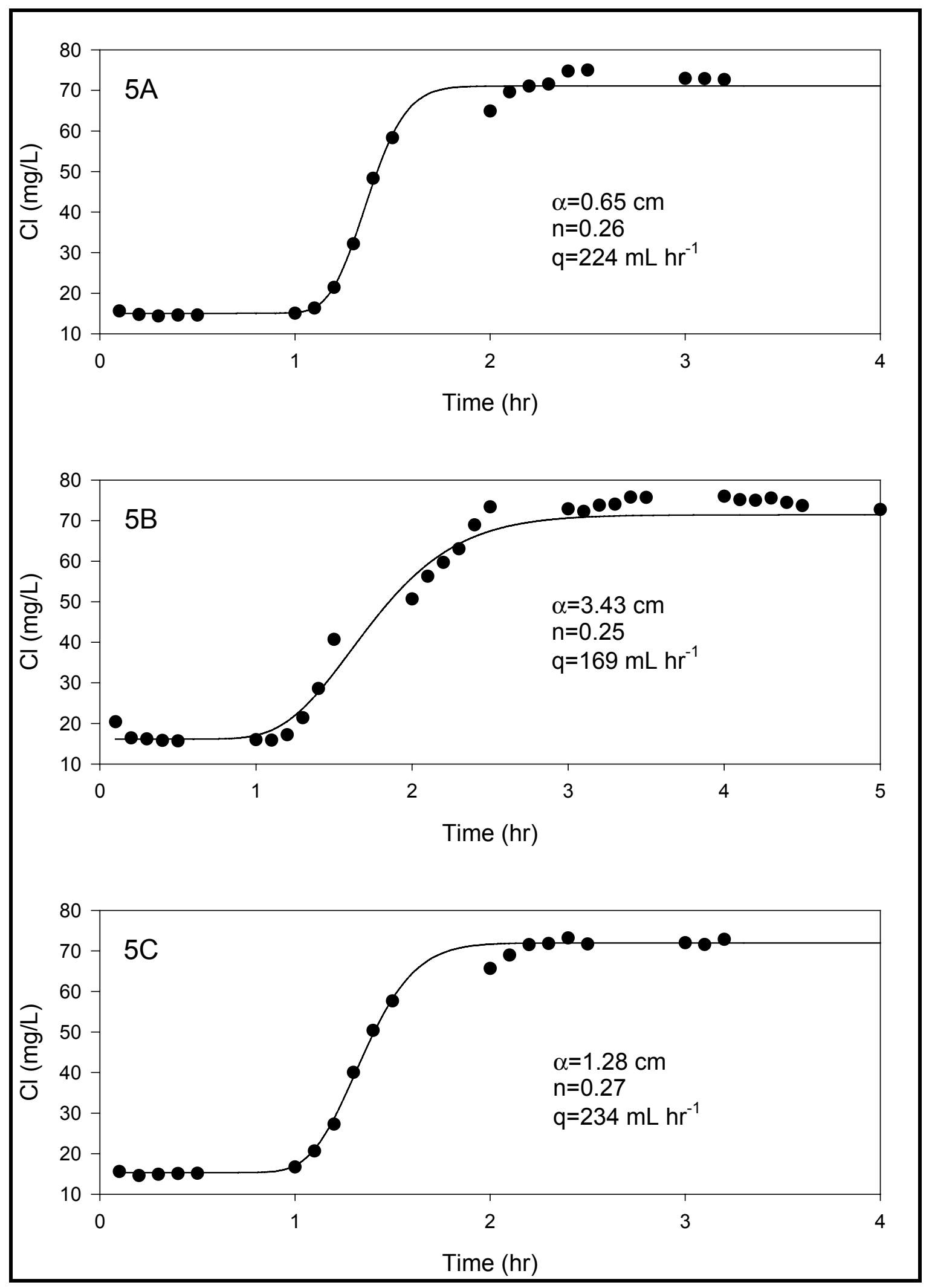

Figure B5. Chloride tracer breakthrough curve for NOP Column Set \#5 


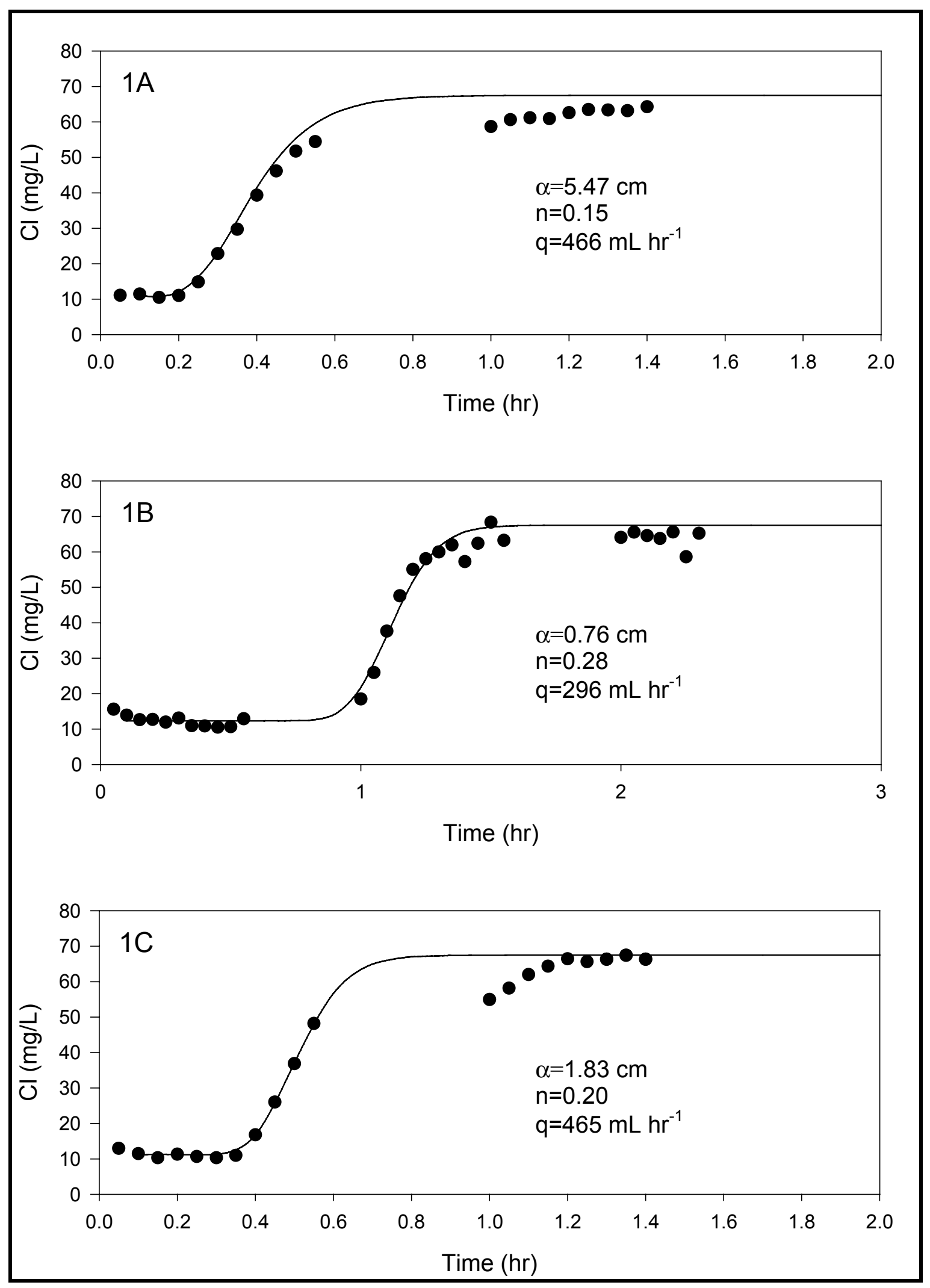

Figure B6. Chloride tracer breakthrough curve for CHAAP Column Set \#1 


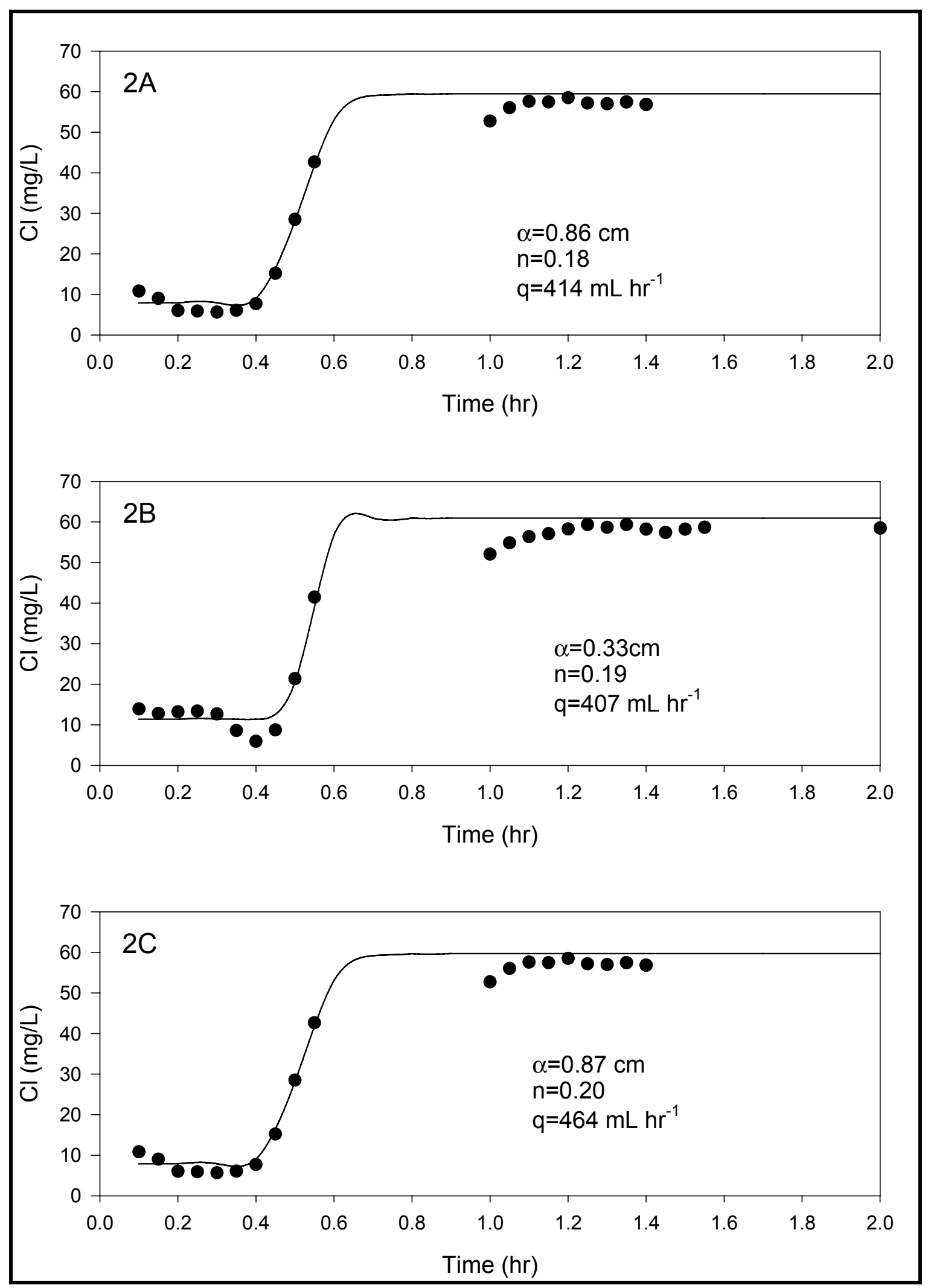

Figure B7. Chloride tracer breakthrough curve for CHAAP Column Set \#2 


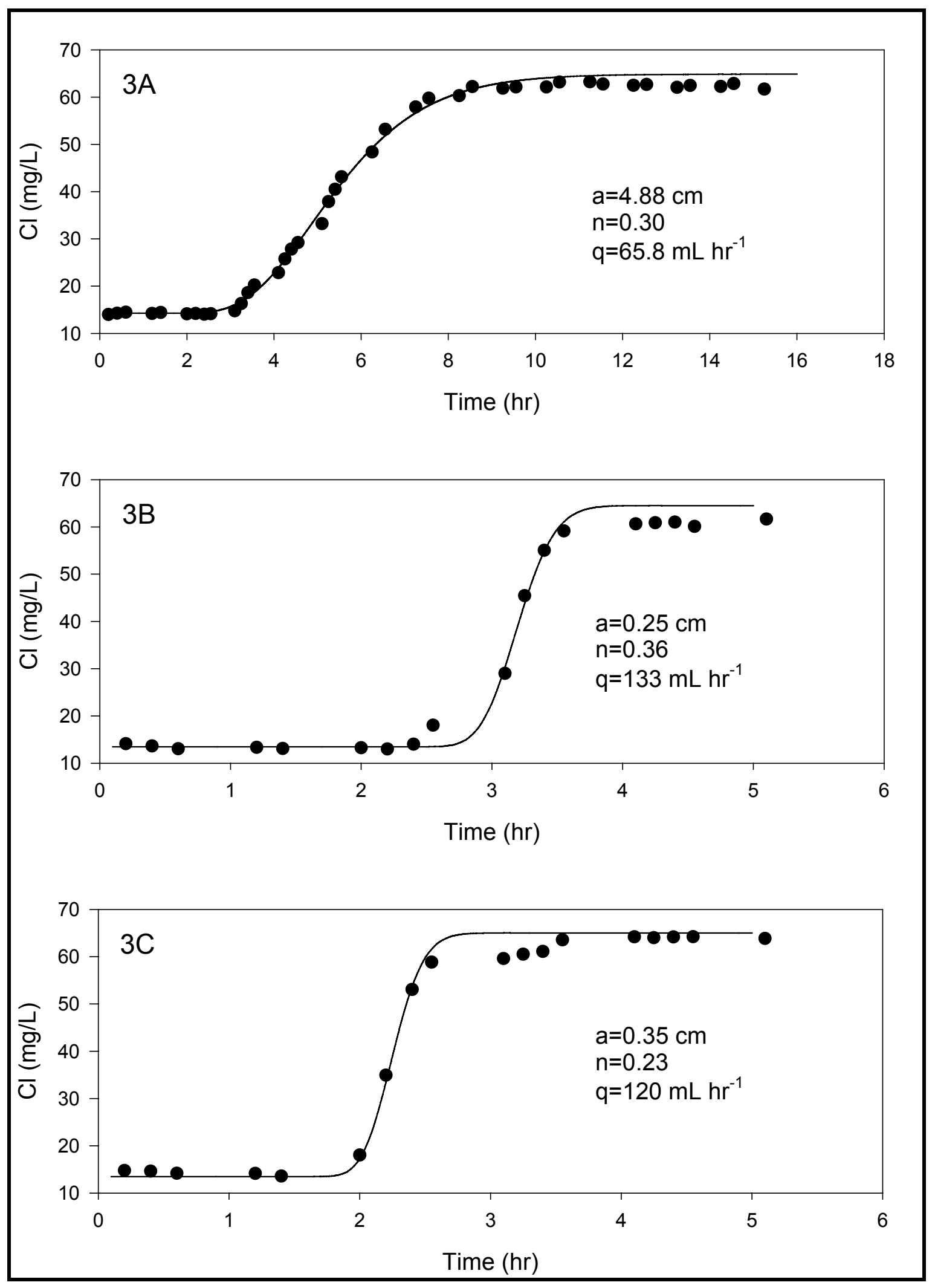

Figure B8. Chloride tracer breakthrough curve for CHAAP Column Set \#3 


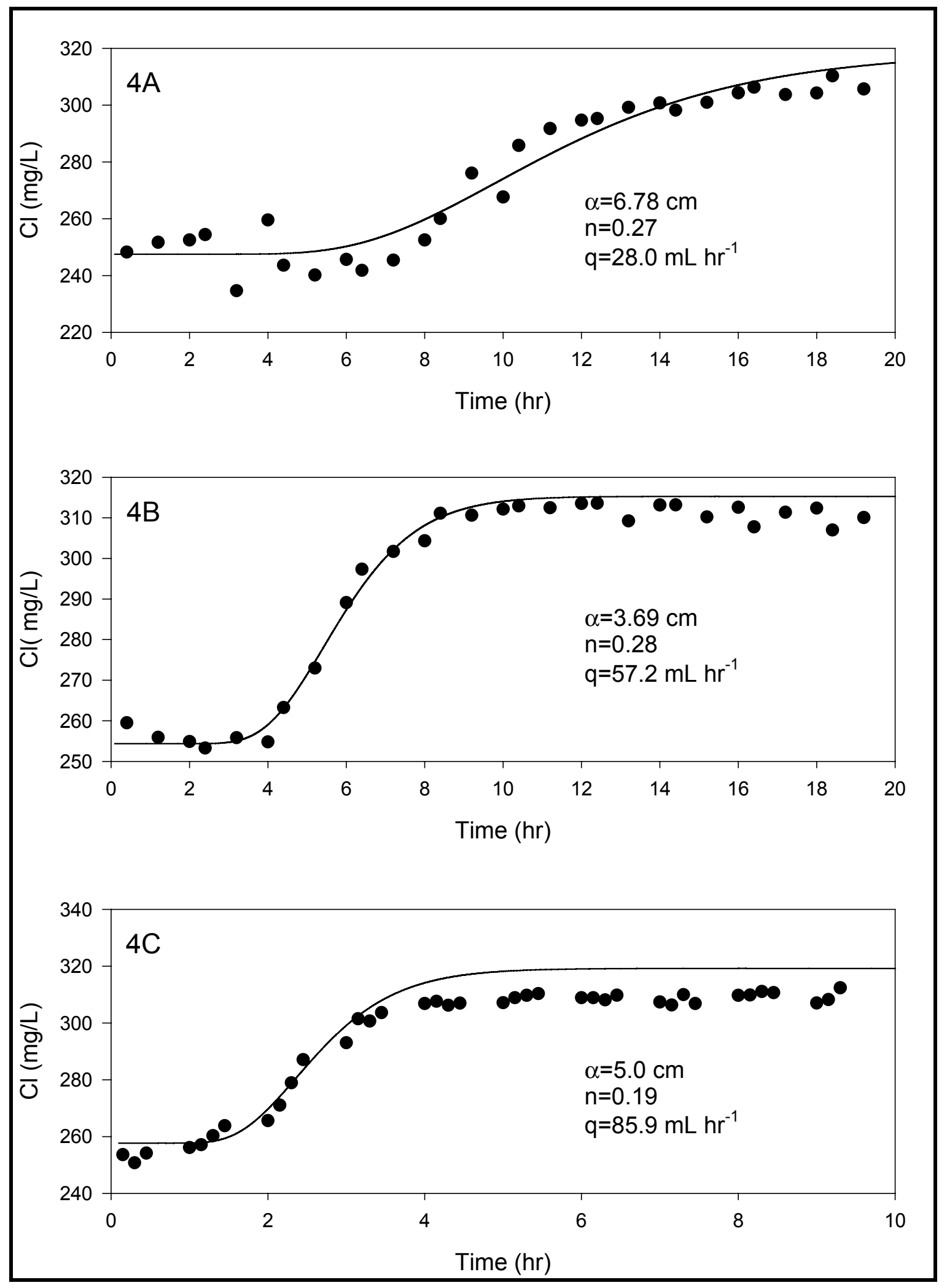

Figure B9. Chloride tracer breakthrough curve for CHAAP Column Set \#4 


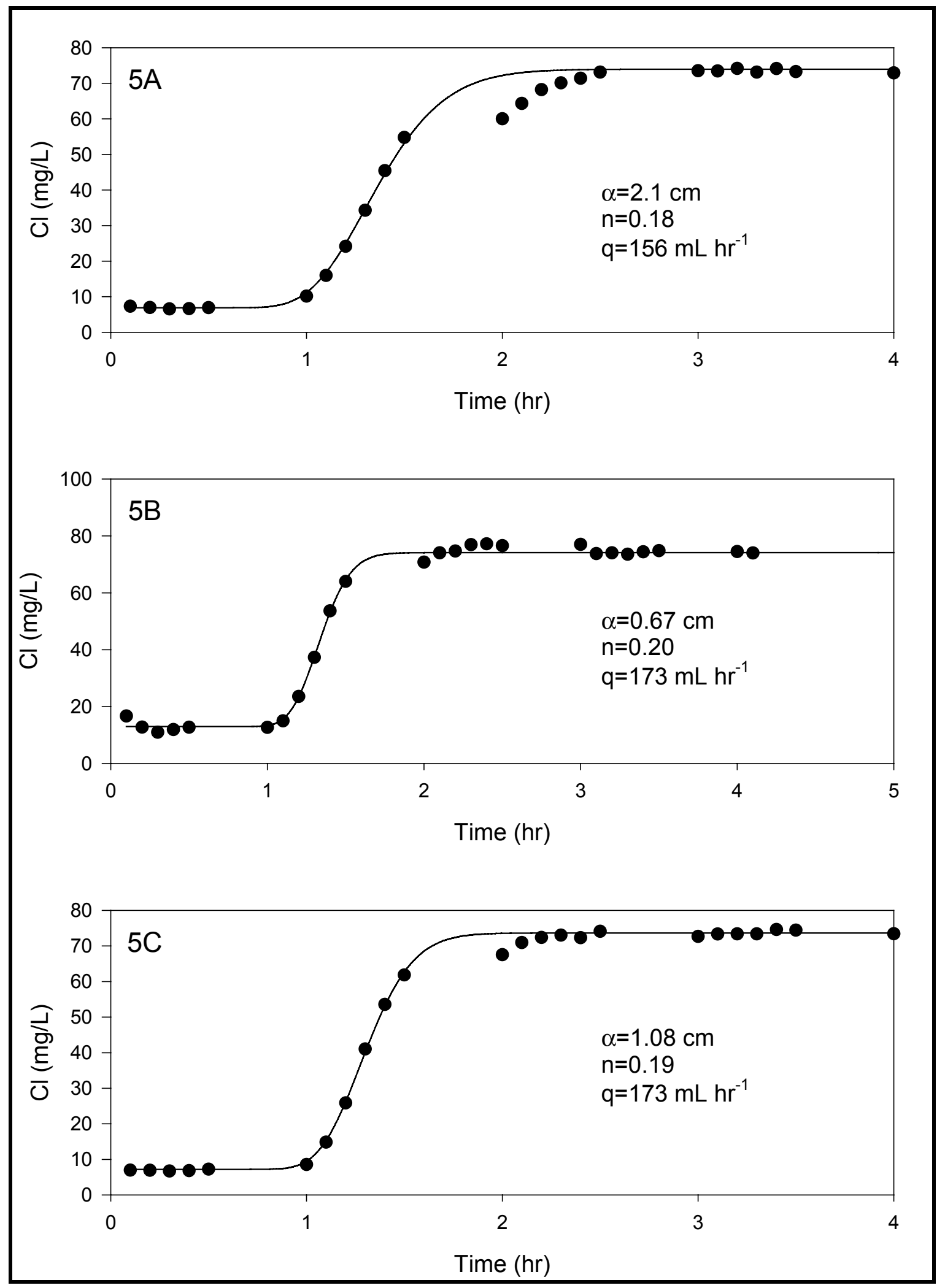

Figure B10. Chloride tracer breakthrough curve for CHAAP Column Set \#5 


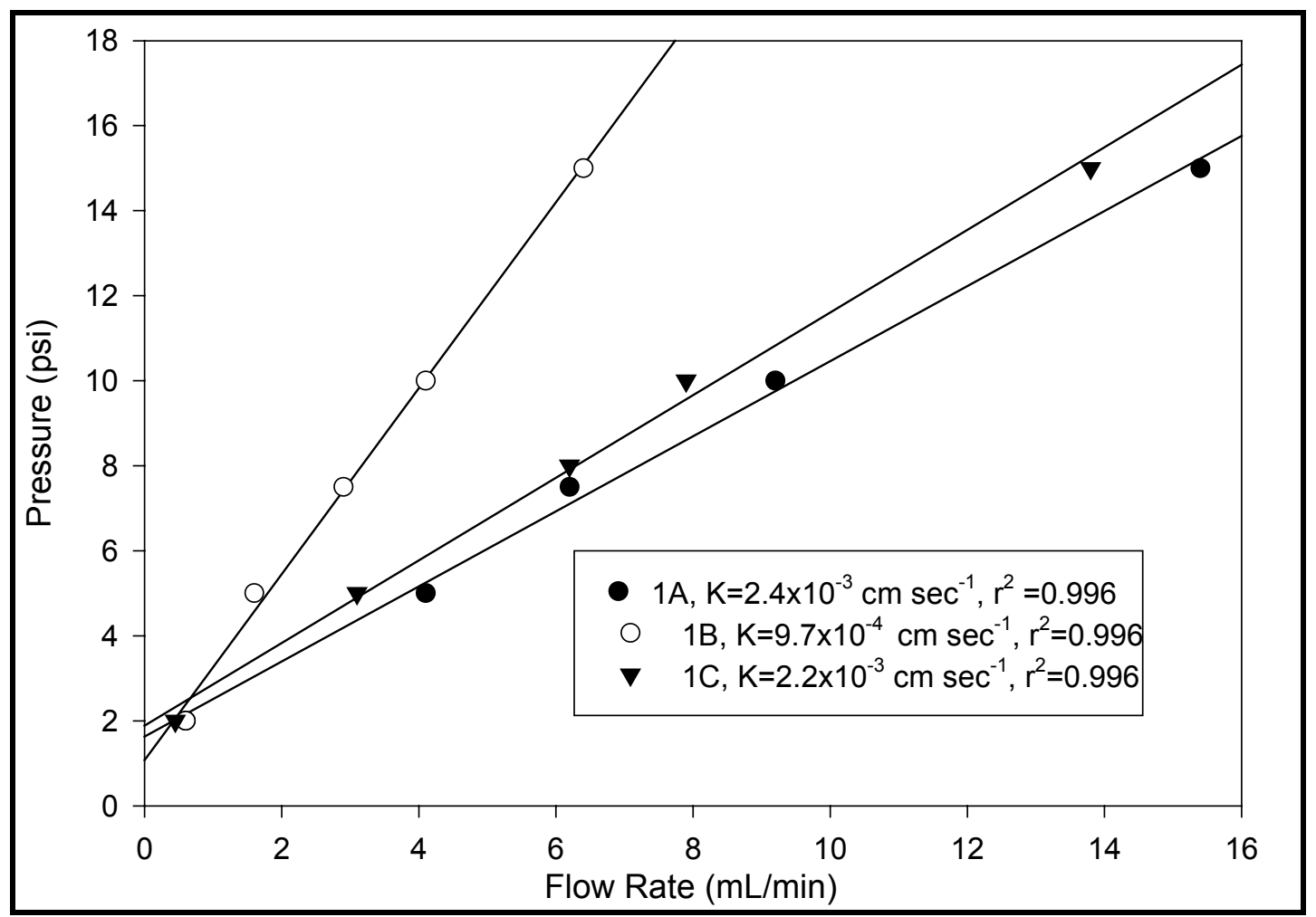

Figure B11. Hydraulic conductivity of NOP aquifer material in Column Set \#1

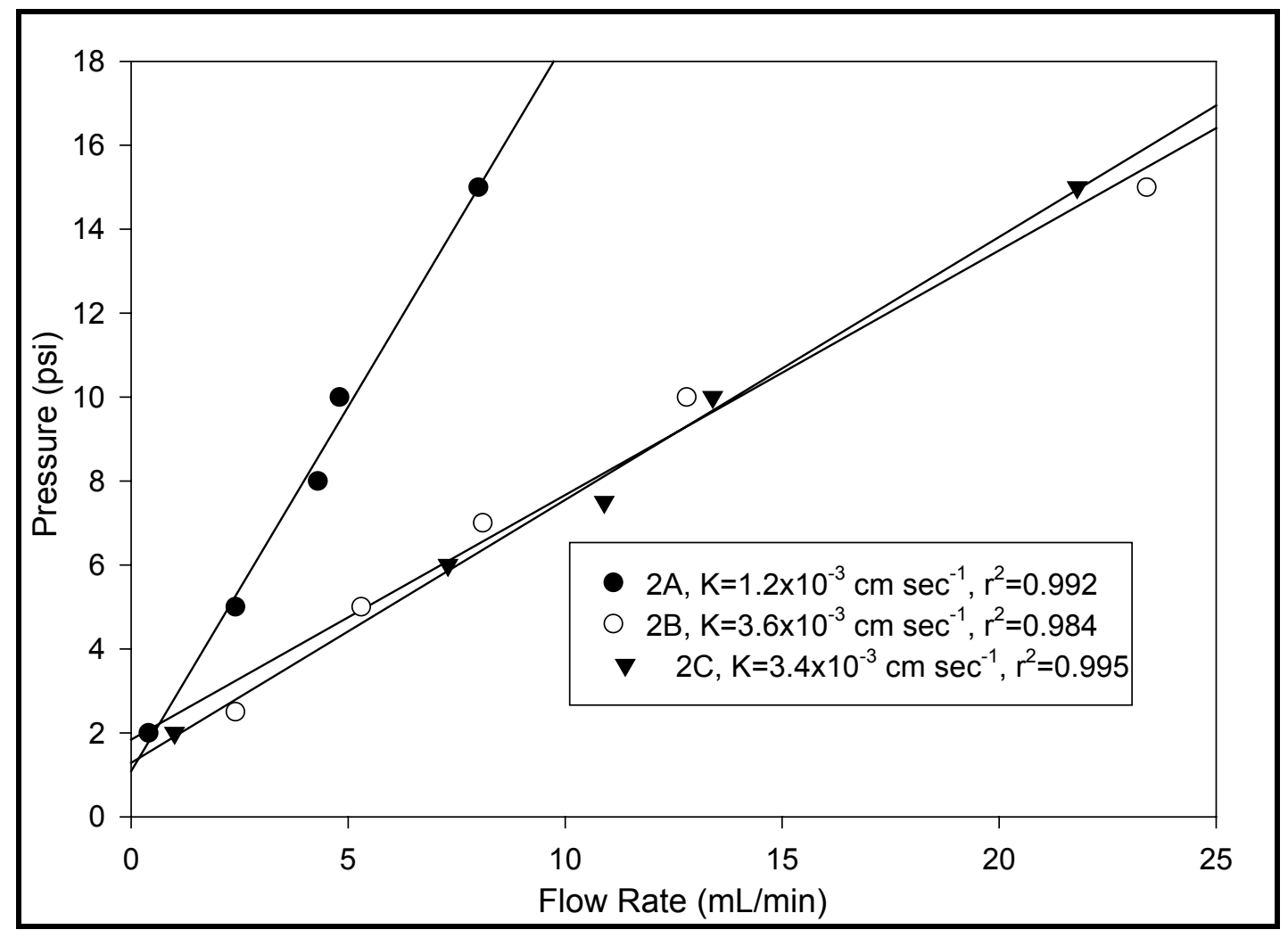

Figure B12. Hydraulic conductivity of NOP aquifer material in Column Set \#2 


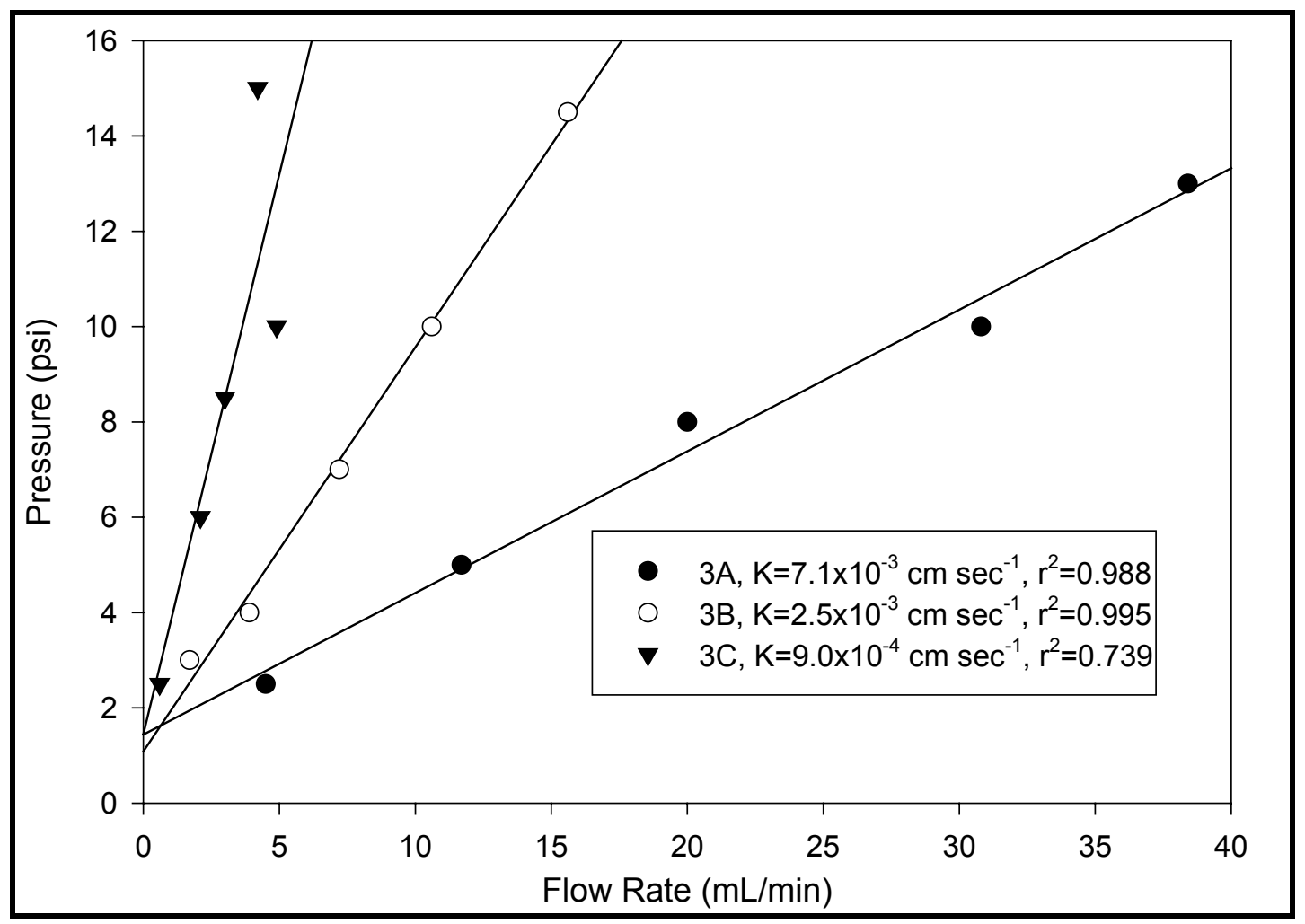

Figure B13. Hydraulic conductivity of NOP aquifer material in Column Set \#3

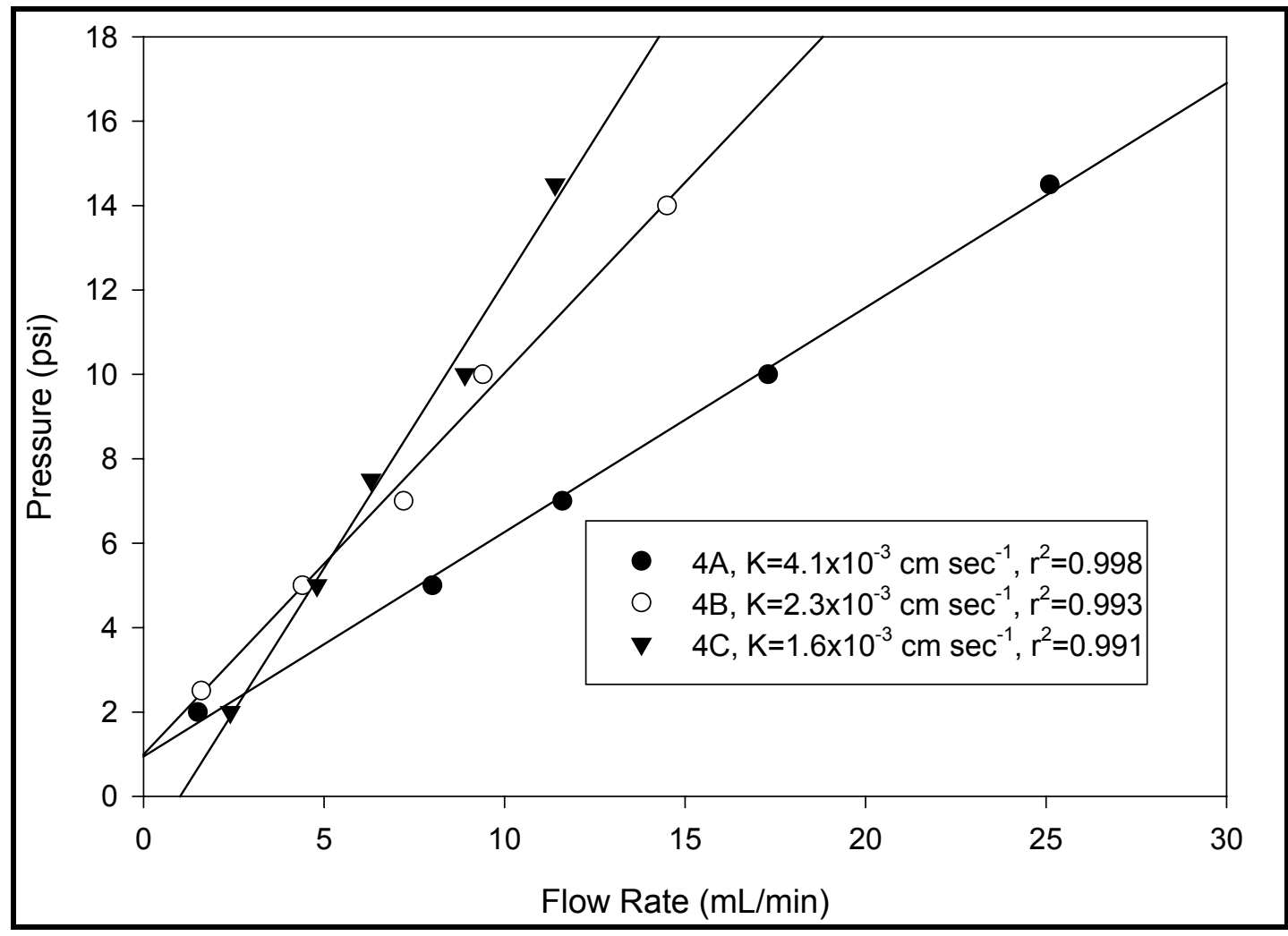

Figure B14. Hydraulic conductivity of NOP aquifer material in Column Set \#4 


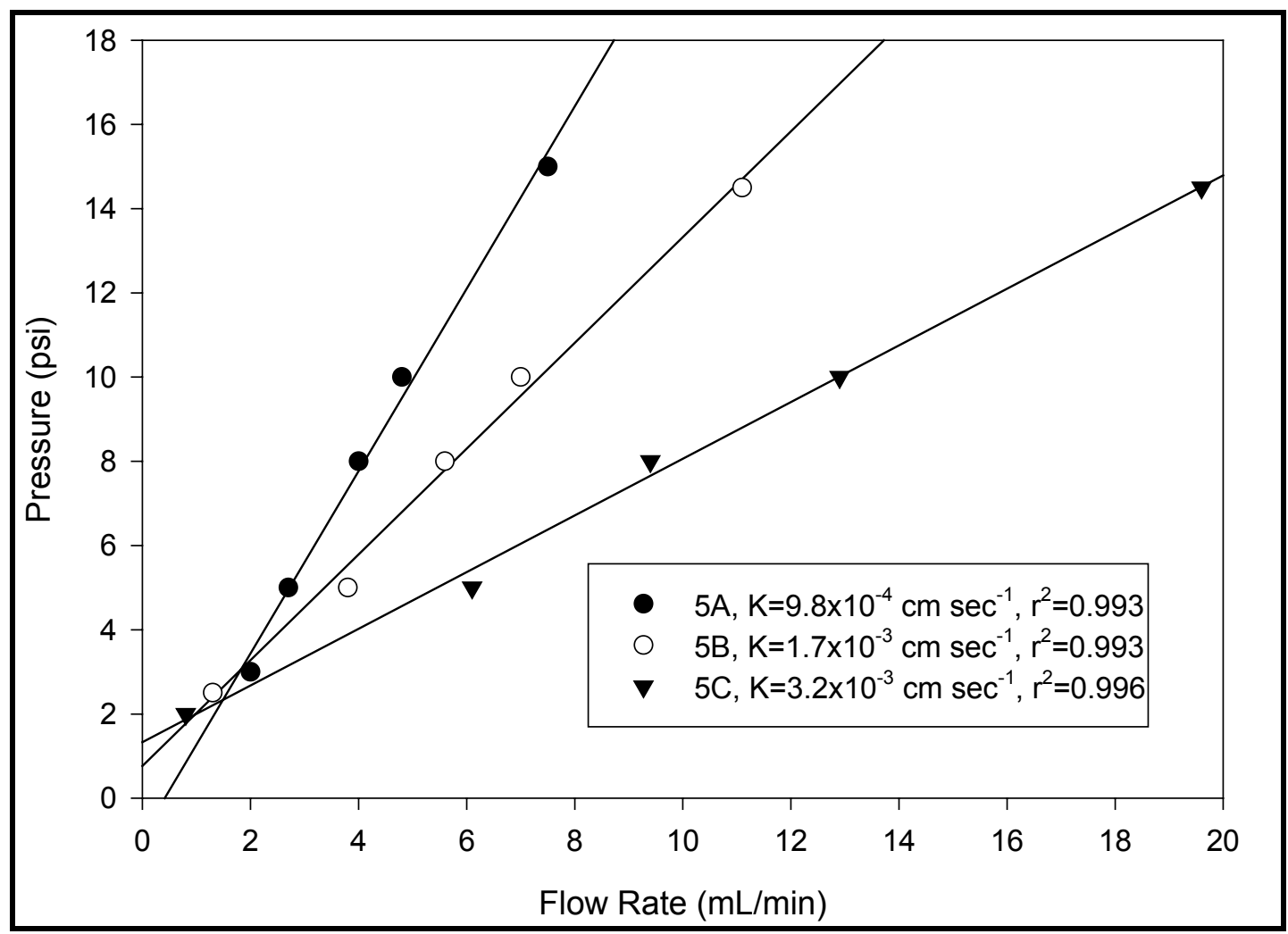

Figure B15. Hydraulic conductivity of NOP aquifer material in Column Set \#5

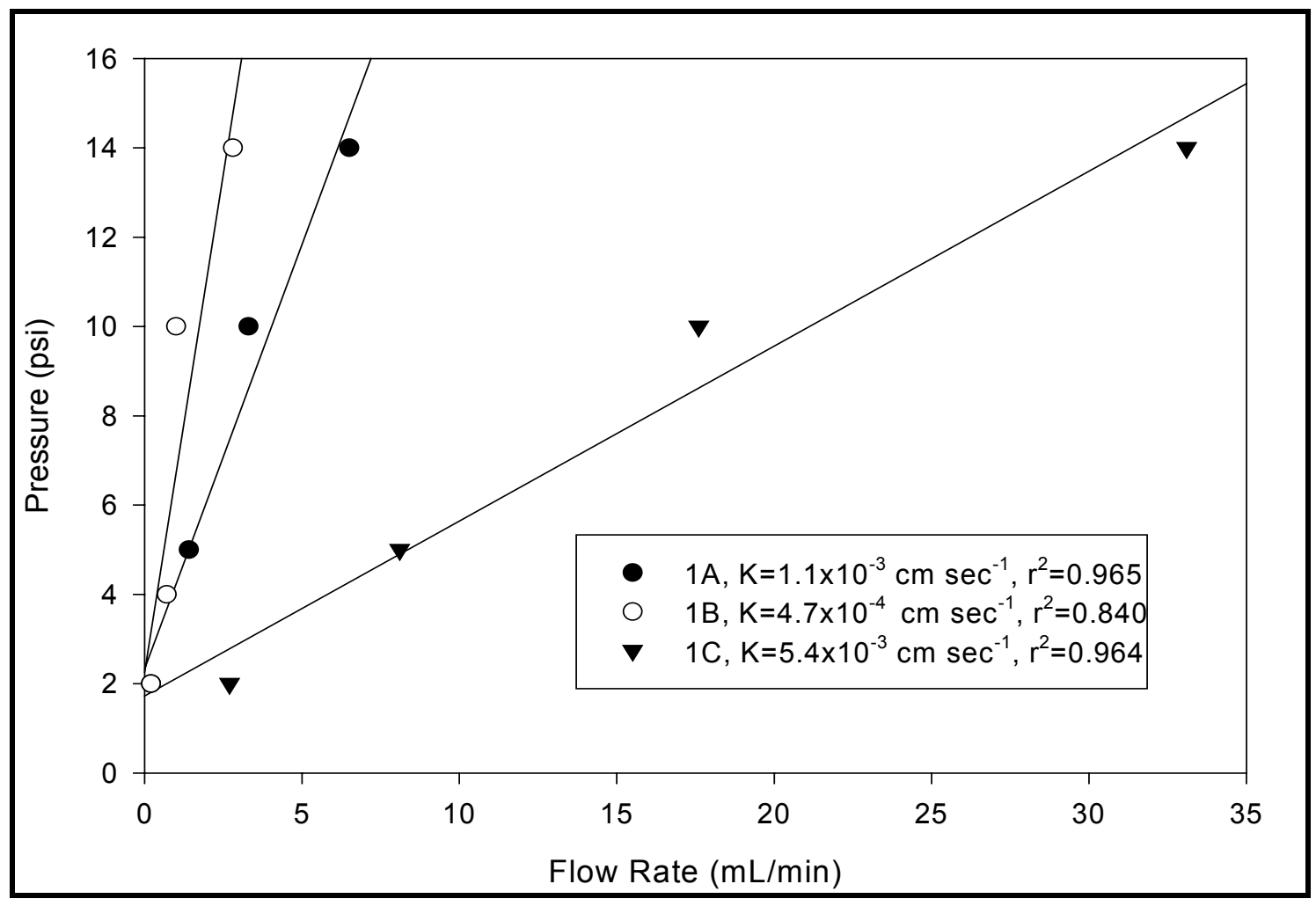

Figure B16. Hydraulic conductivity of CHAAP aquifer material in Column Set \#1 


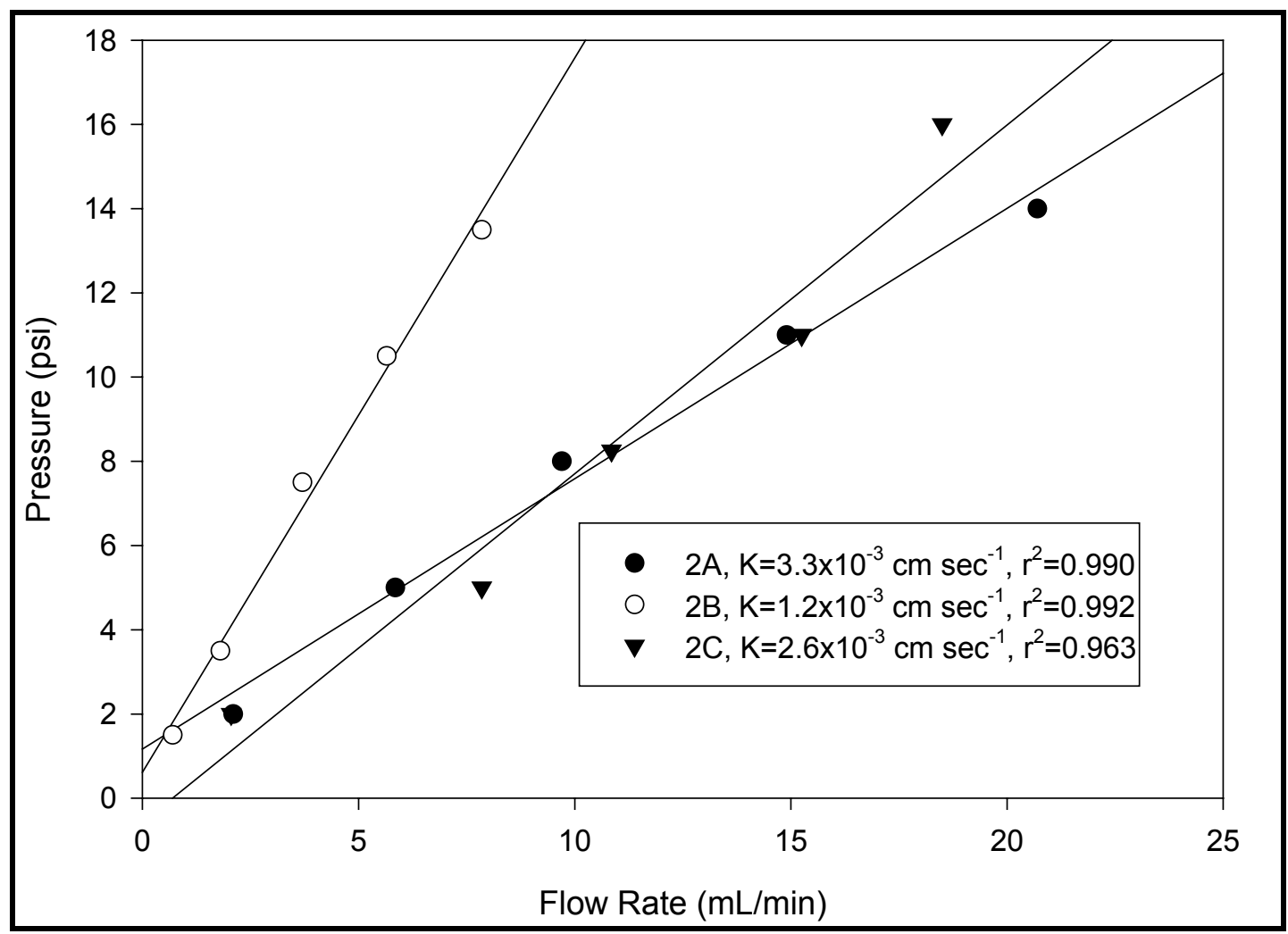

Figure B17. Hydraulic conductivity of CHAAP aquifer material in Column Set \#2

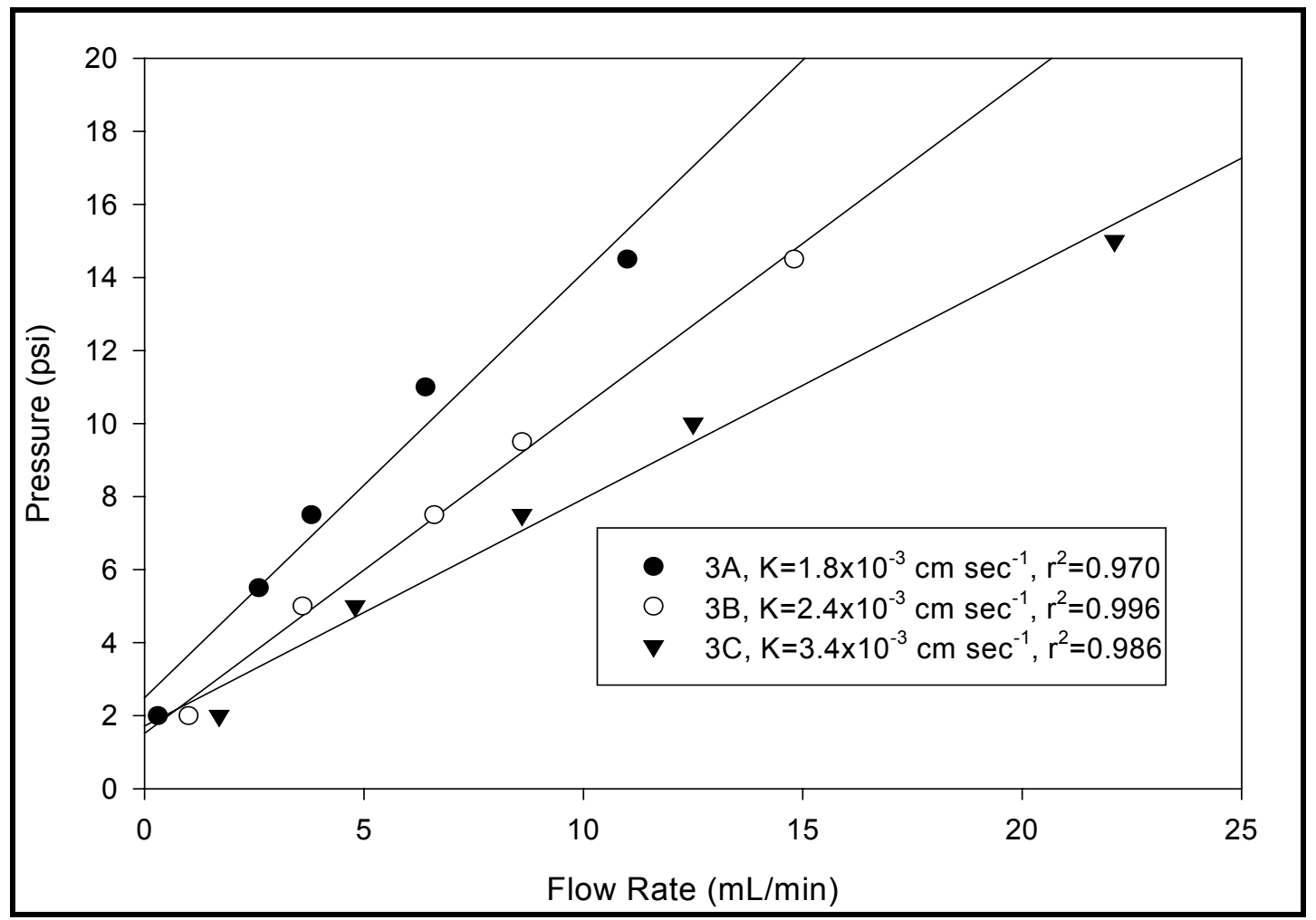

Figure B18. Hydraulic conductivity of CHAAP aquifer material in Column Set \#3 


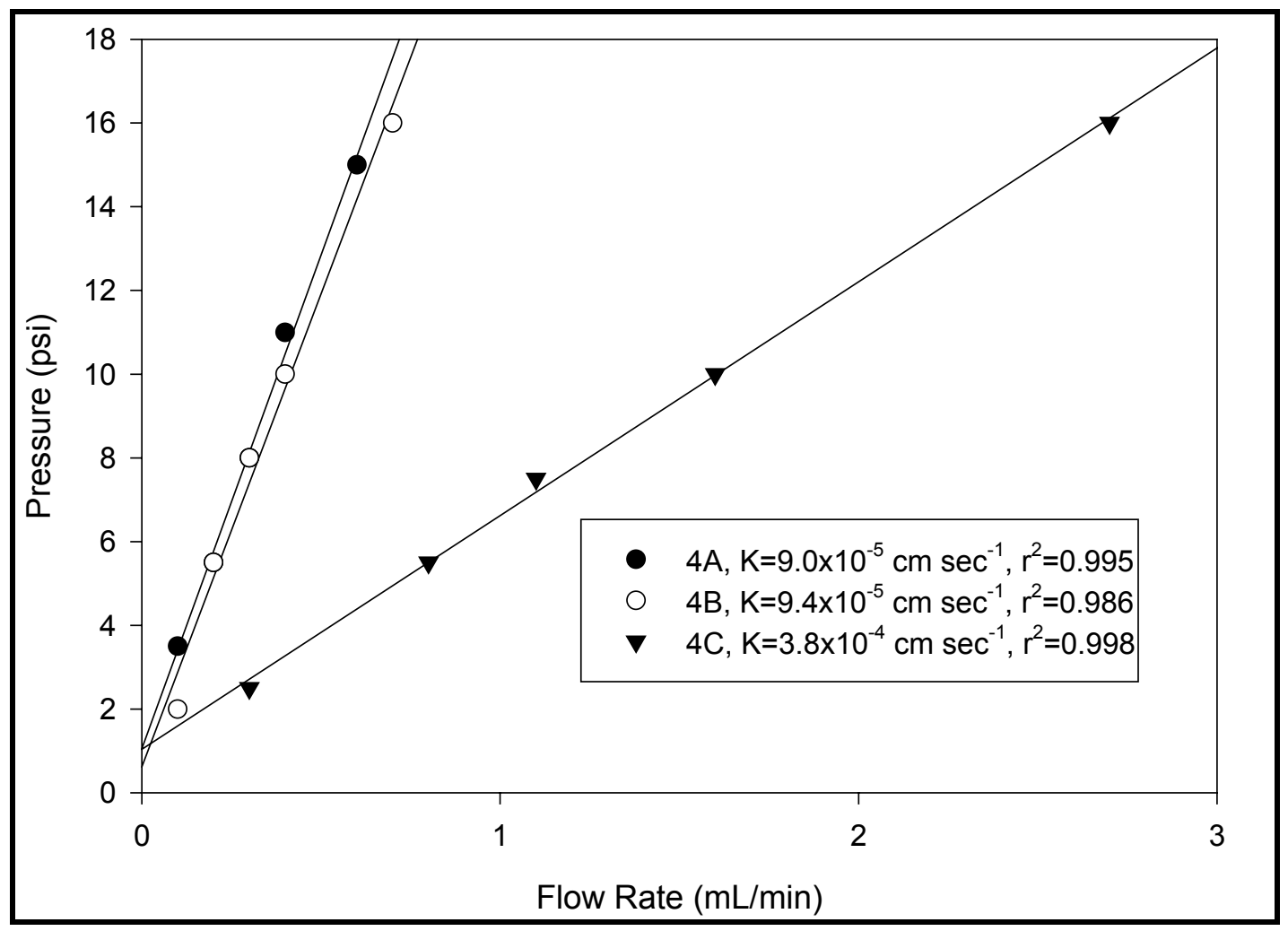

Figure B19. Hydraulic conductivity of CHAAP aquifer material in Column Set \#4

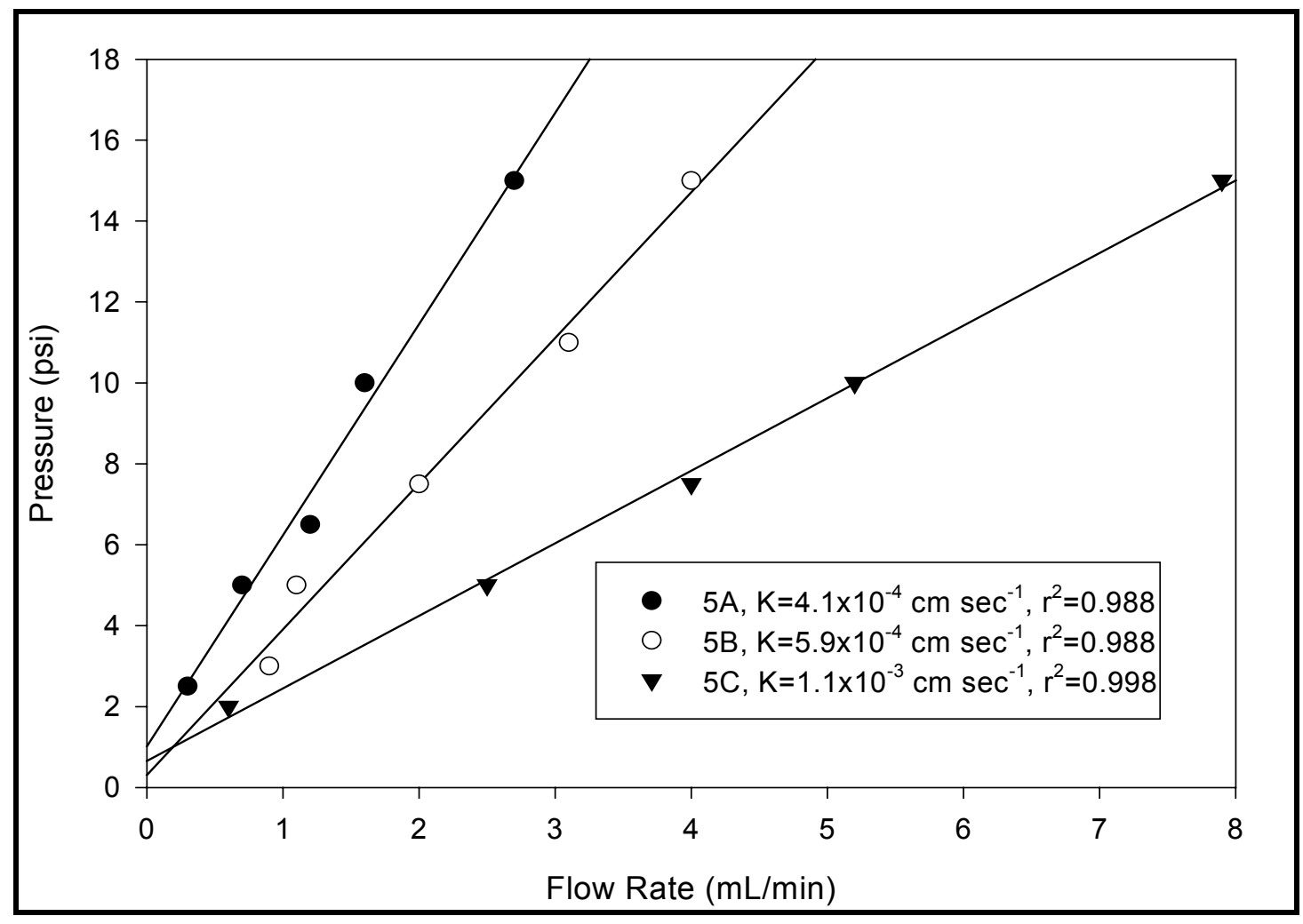

Figure B20. Hydraulic conductivity of CHAAP aquifer material in Column Set \#5 

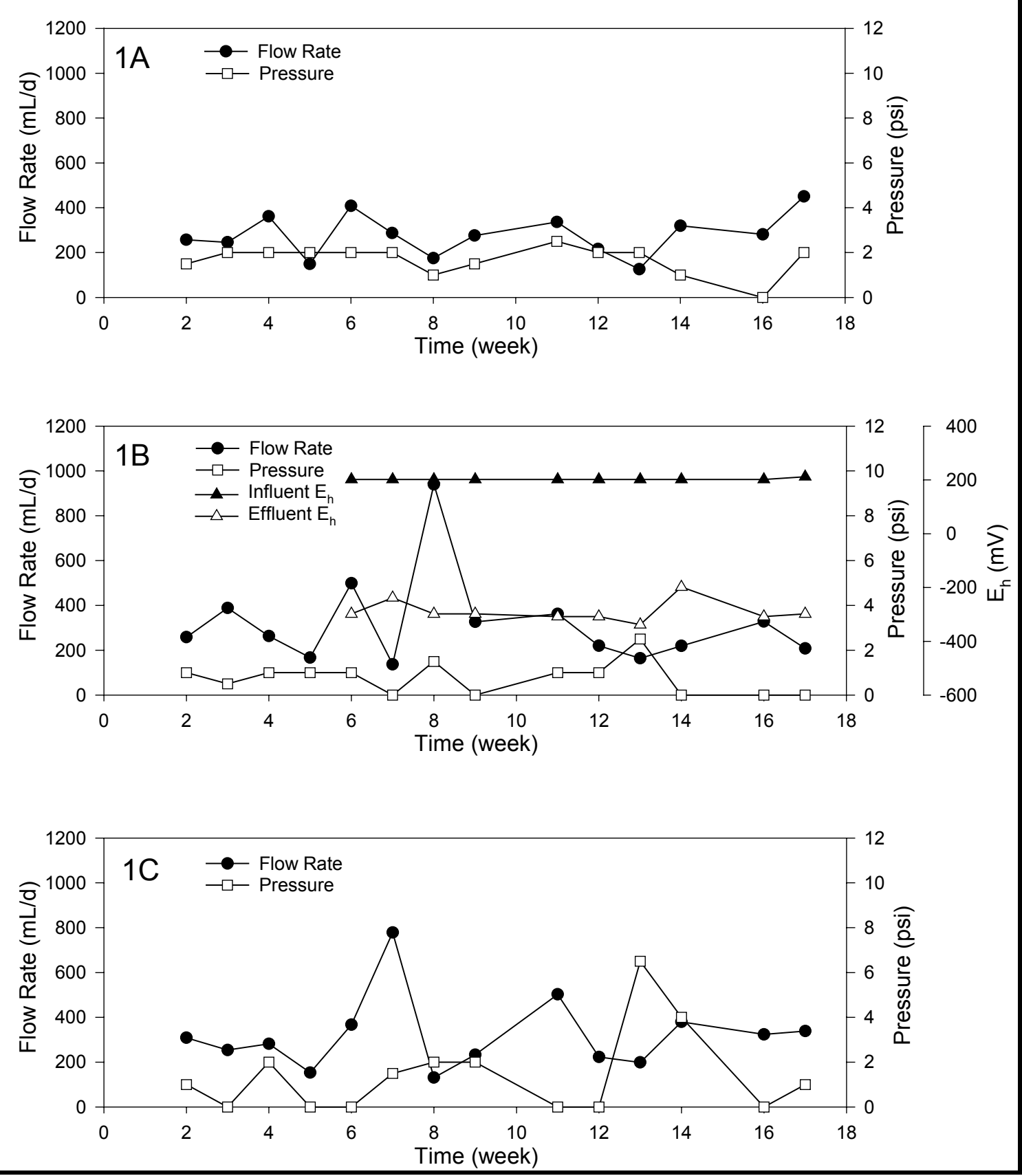

Figure B21. Column operating parameters for NOP Column Set \#1 

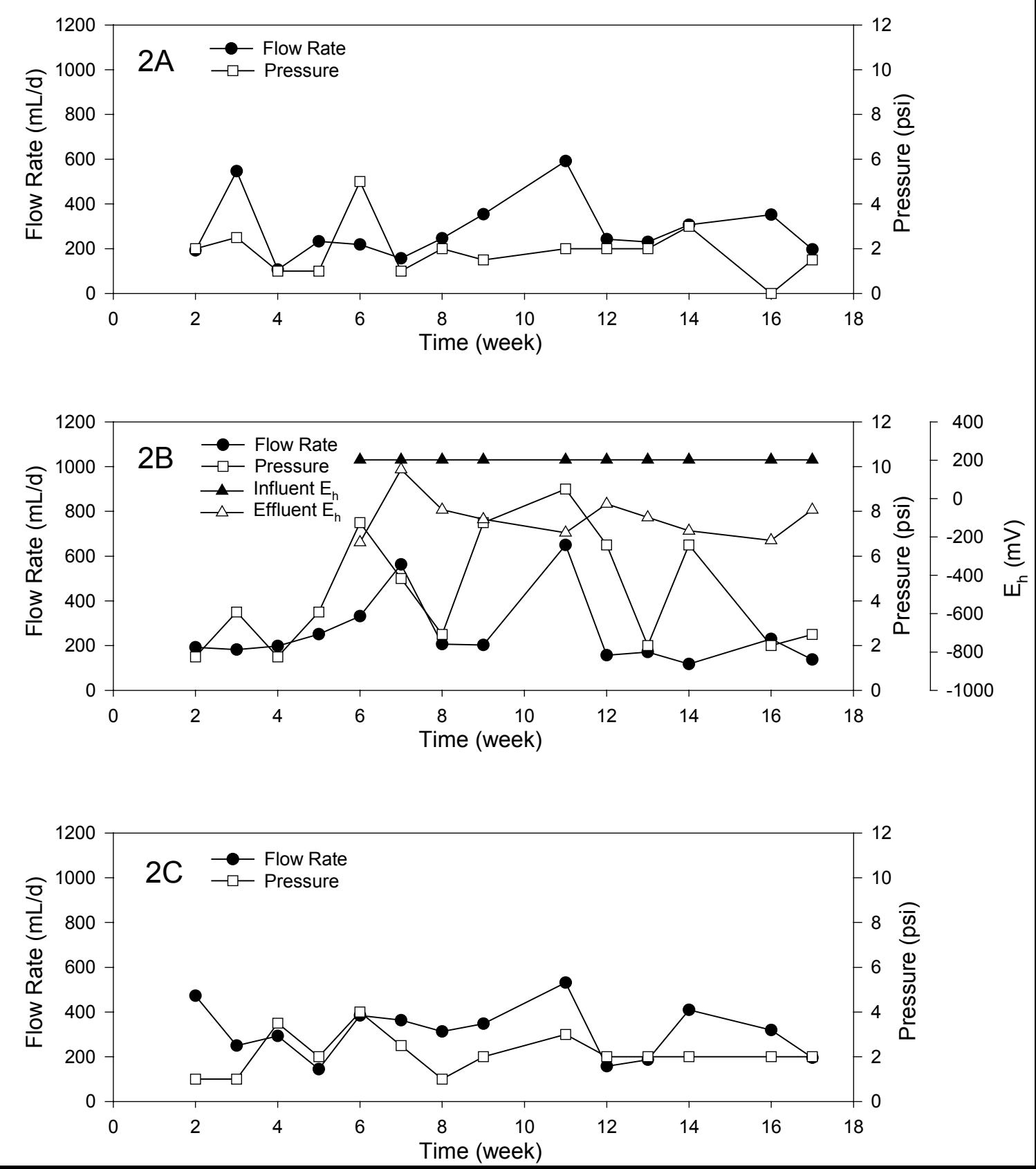

Figure B22. Column operating parameters for NOP Column Set \#2 

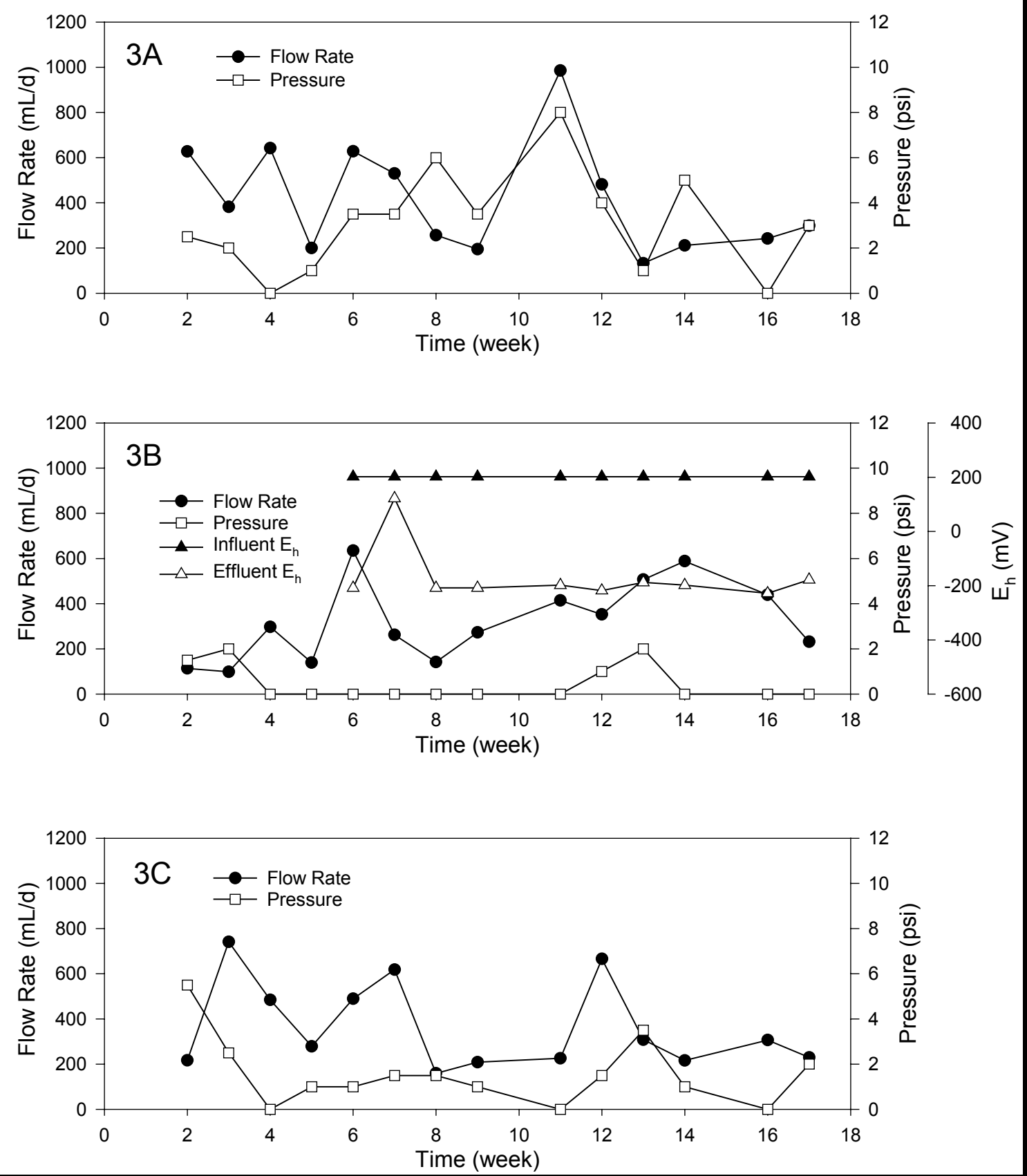

Figure B23. Column operating parameters for NOP Column Set \#3 

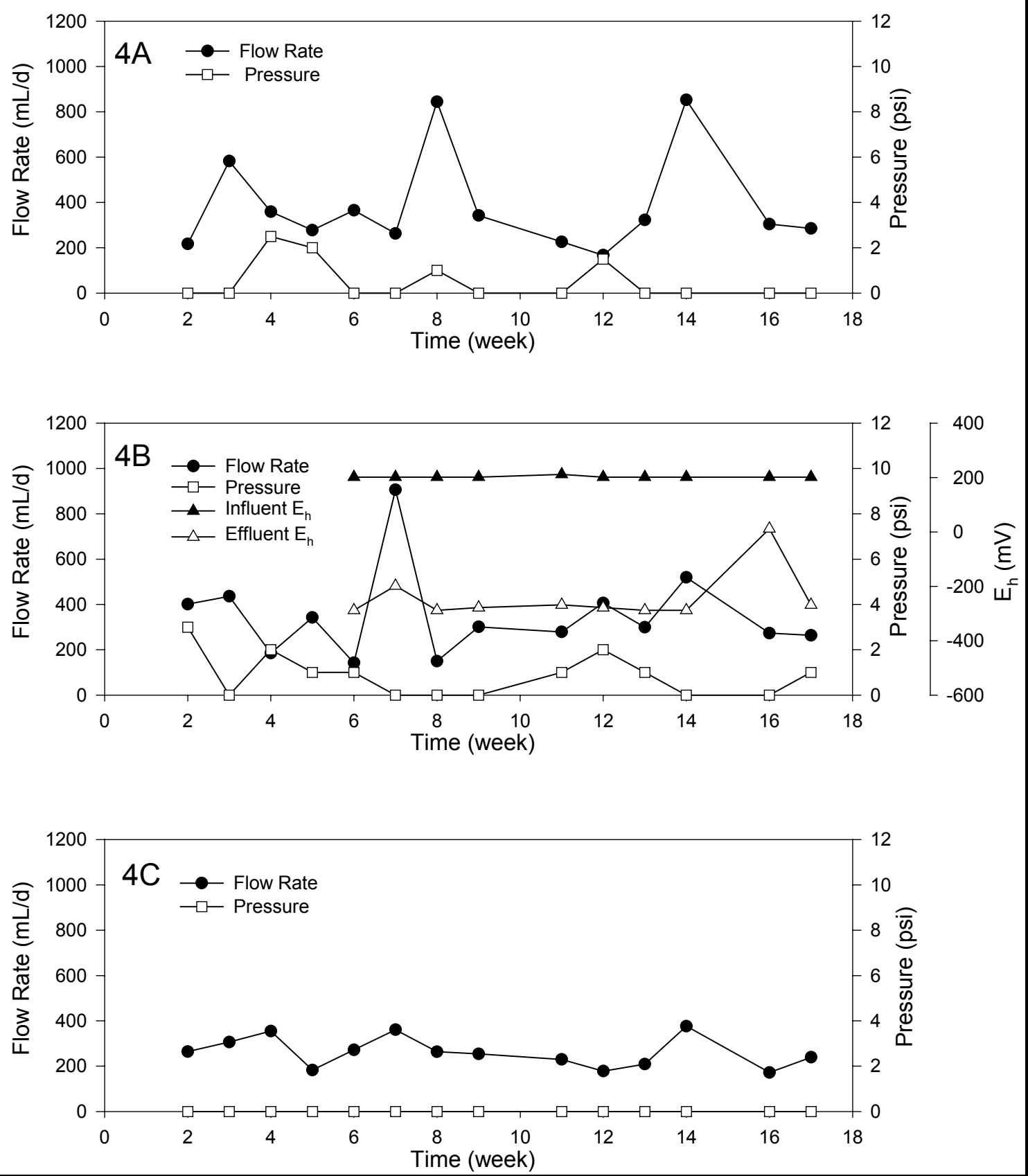

Figure B24. Column operating parameters for NOP Column Set \#4 

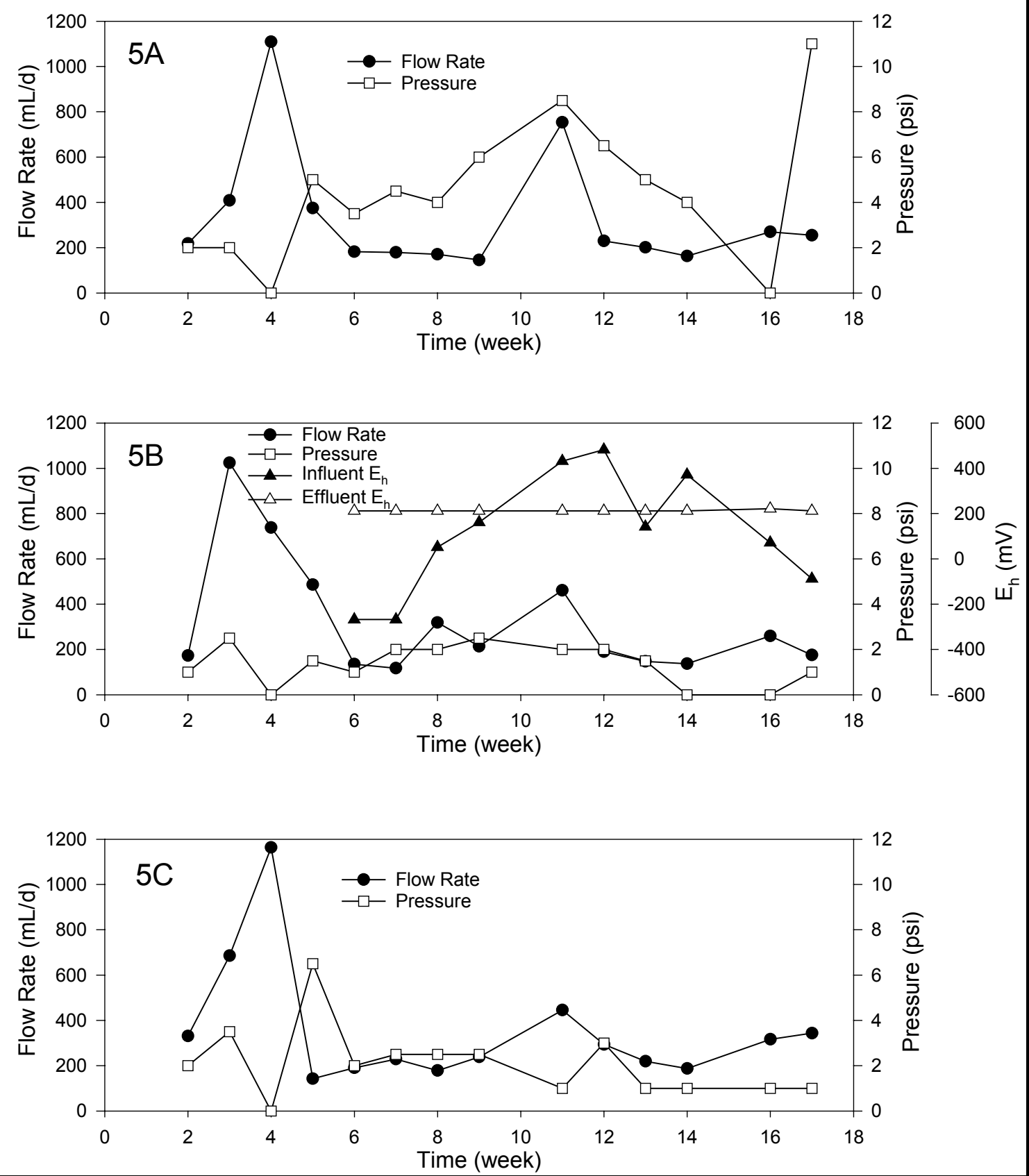

Figure B25. Column operating parameters for NOP Column Set \#5 

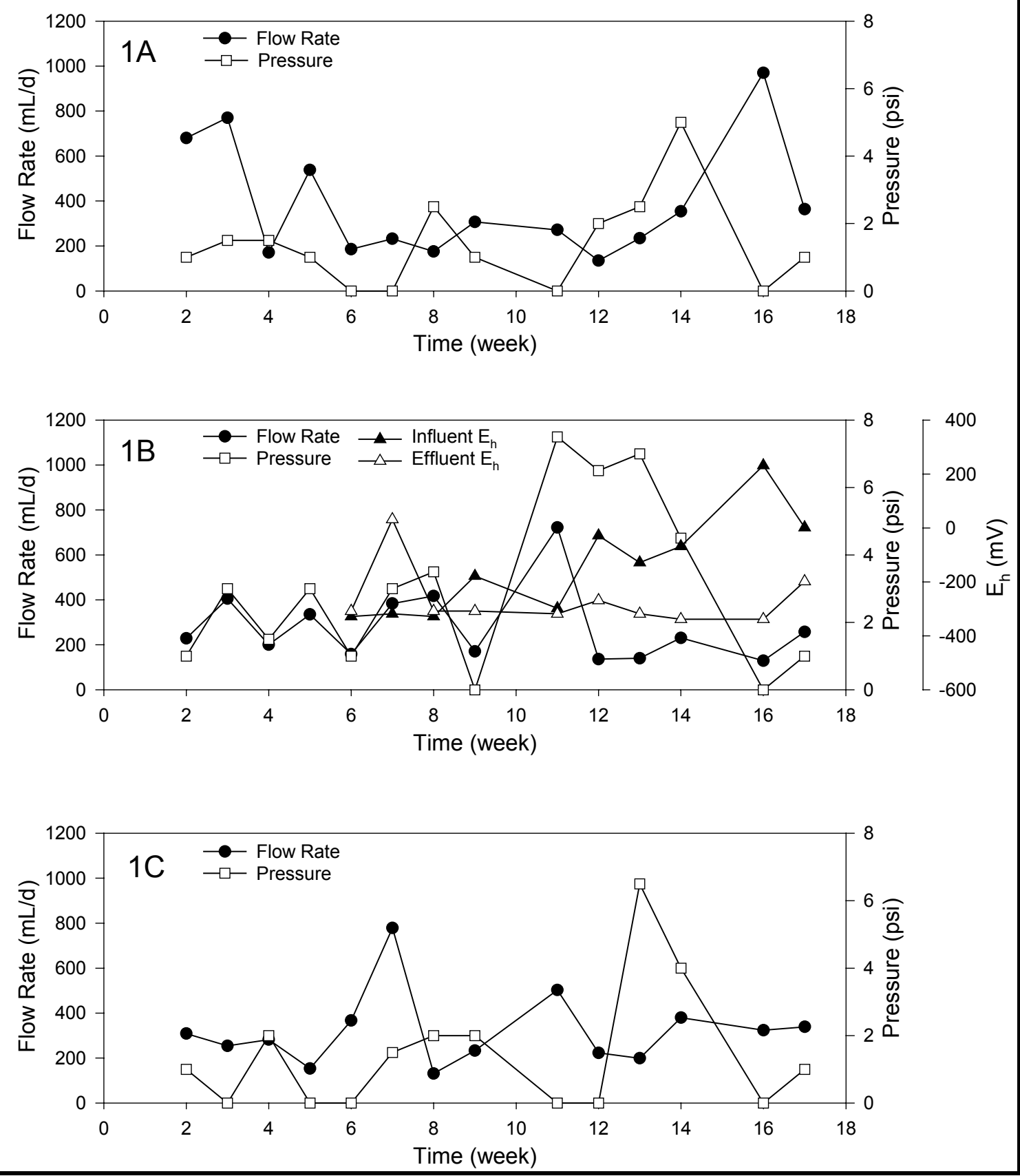

Figure B26. Column operating parameters for CHAAP Column Set \#1 

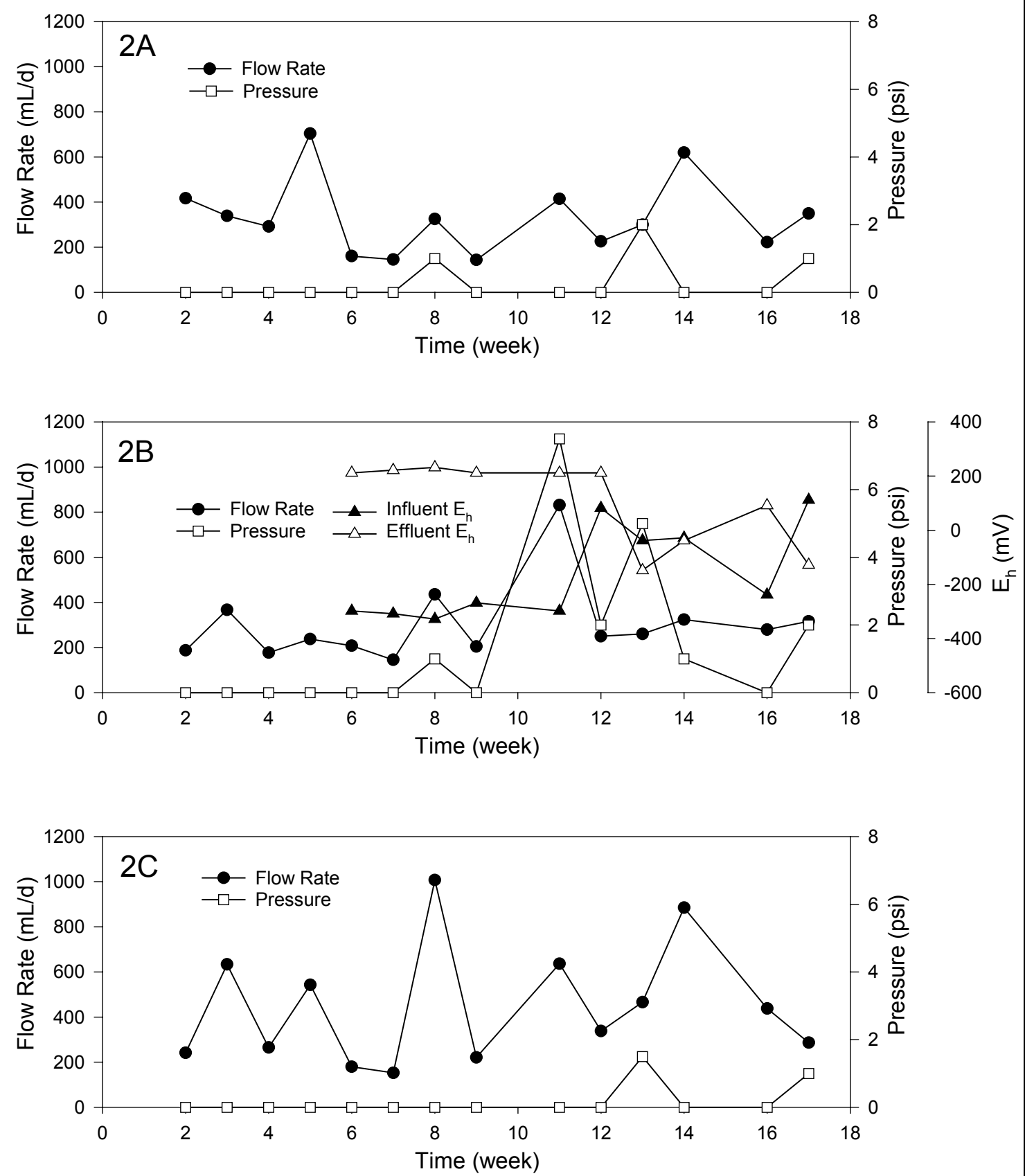

Figure B27. Column operating parameters for CHAAP Column Set \#2 

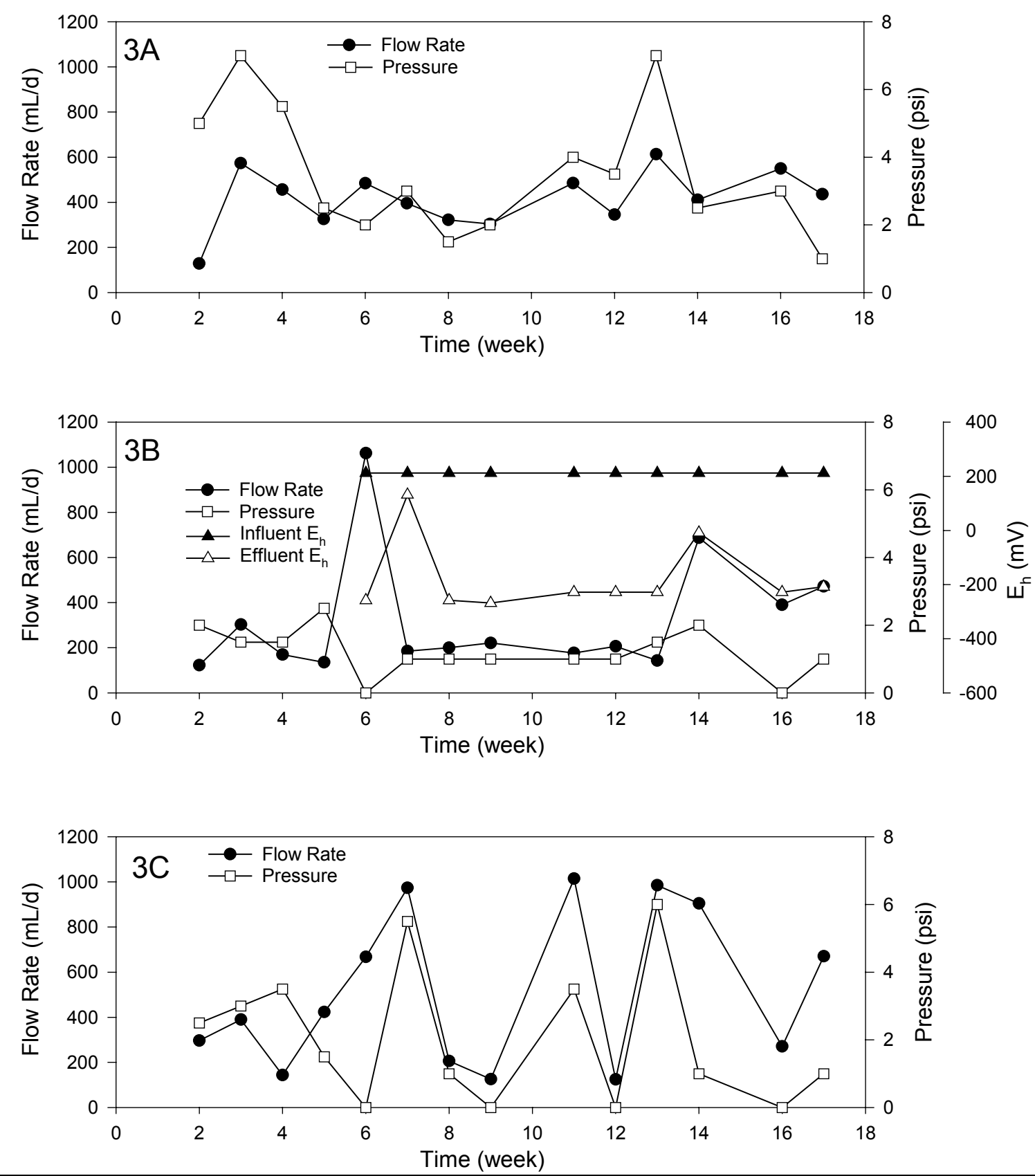

Figure B28. Column operating parameters for CHAAP Column Set \#3 

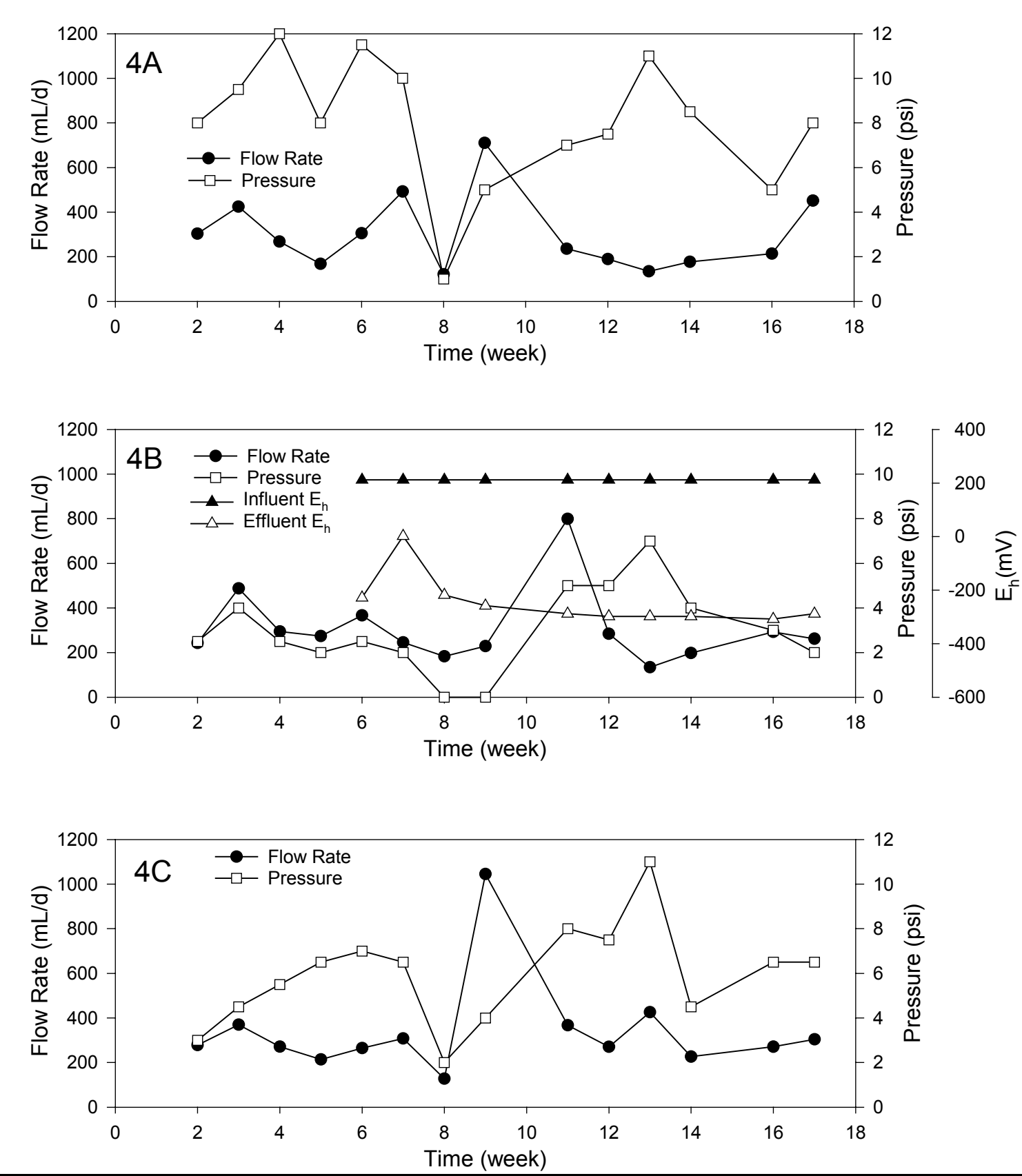

Figure B29. Column operating parameters for CHAAP Column Set \#4 

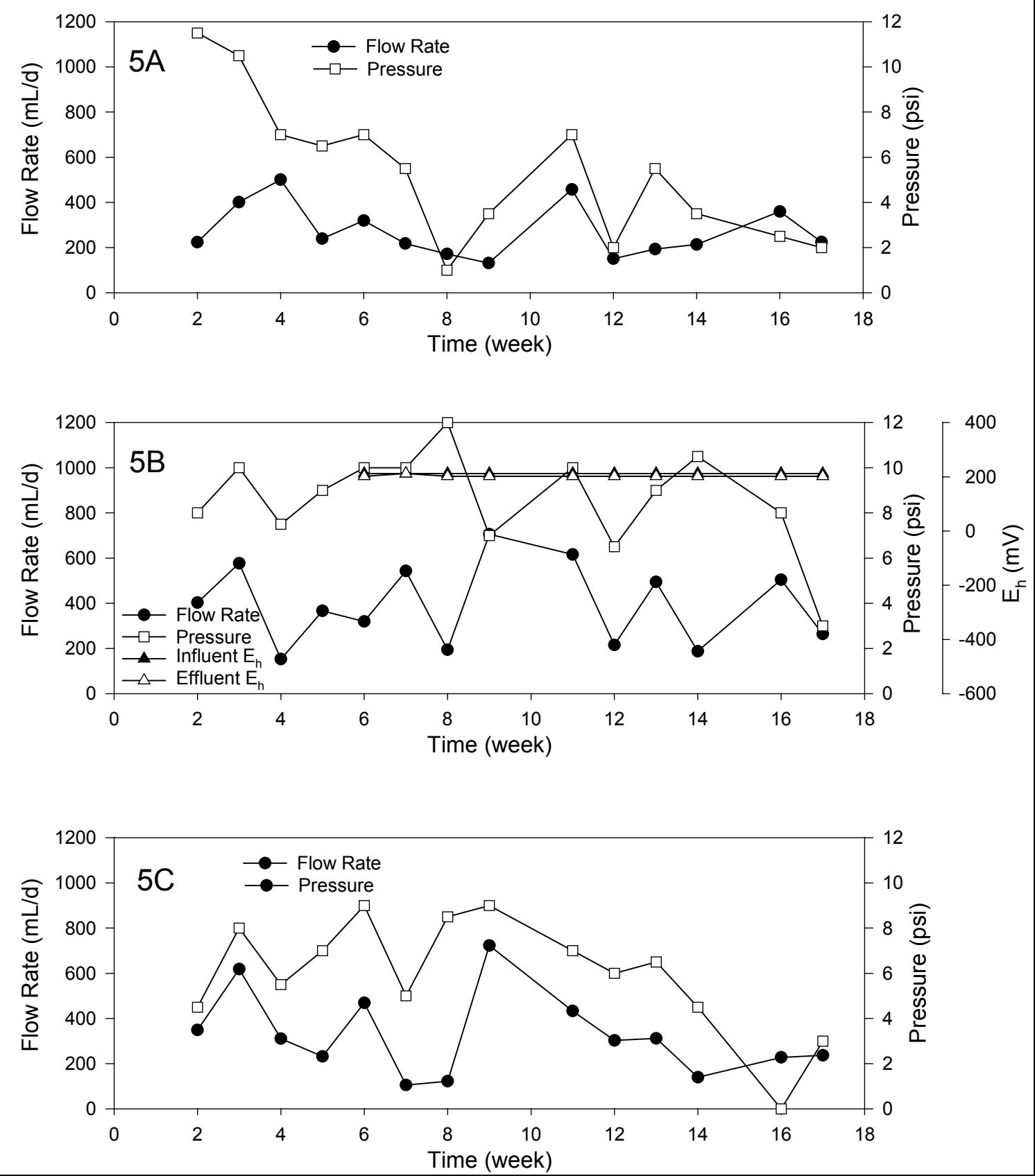

Figure B30. Column operating parameters for CHAAP Column Set \#5 


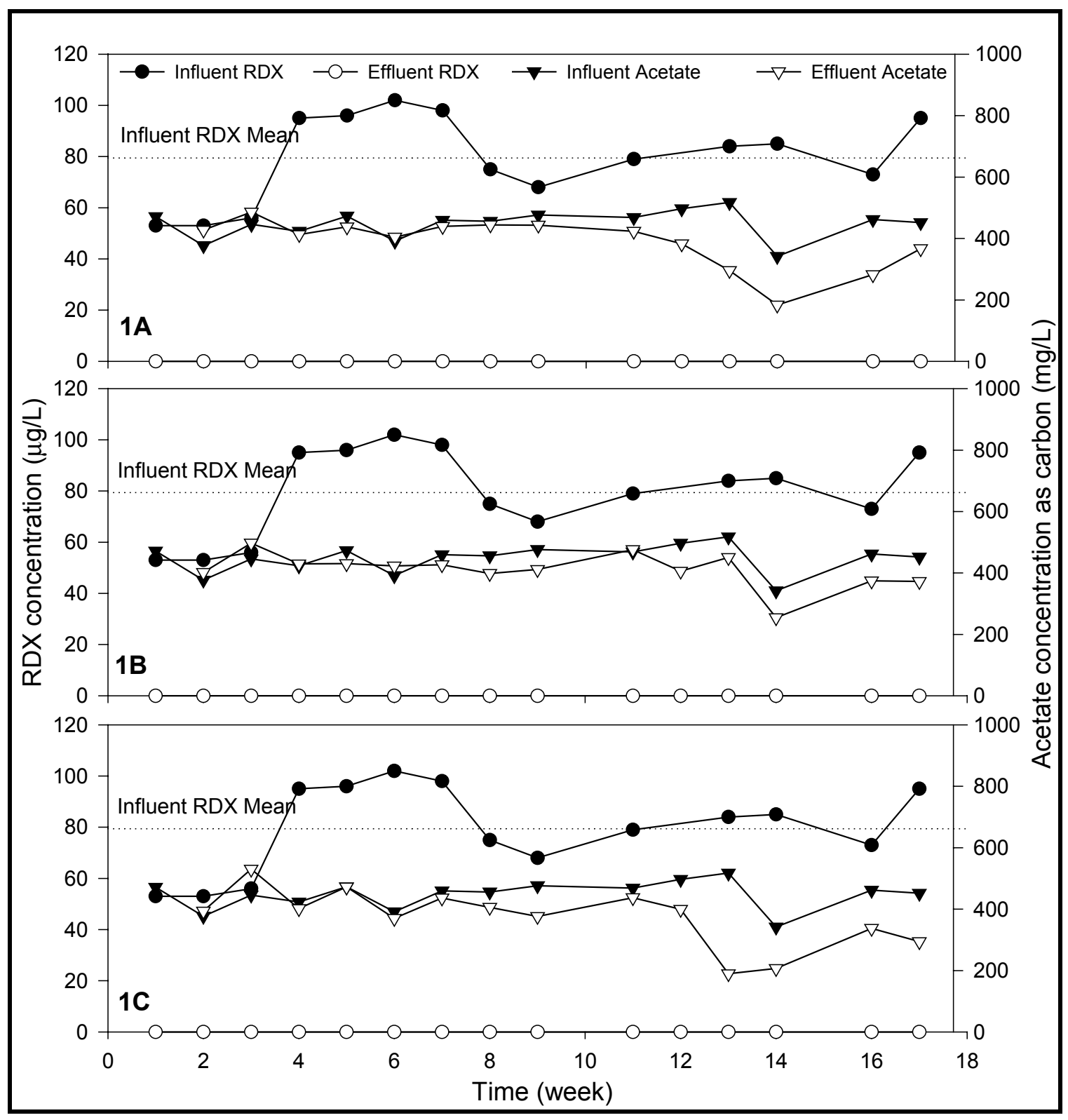

Figure B31. RDX removal from NOP groundwater amended with acetate (Acetate concentration $=500 \mathrm{mg} \mathrm{L}^{-1}$ as $\mathrm{C}$ ) 


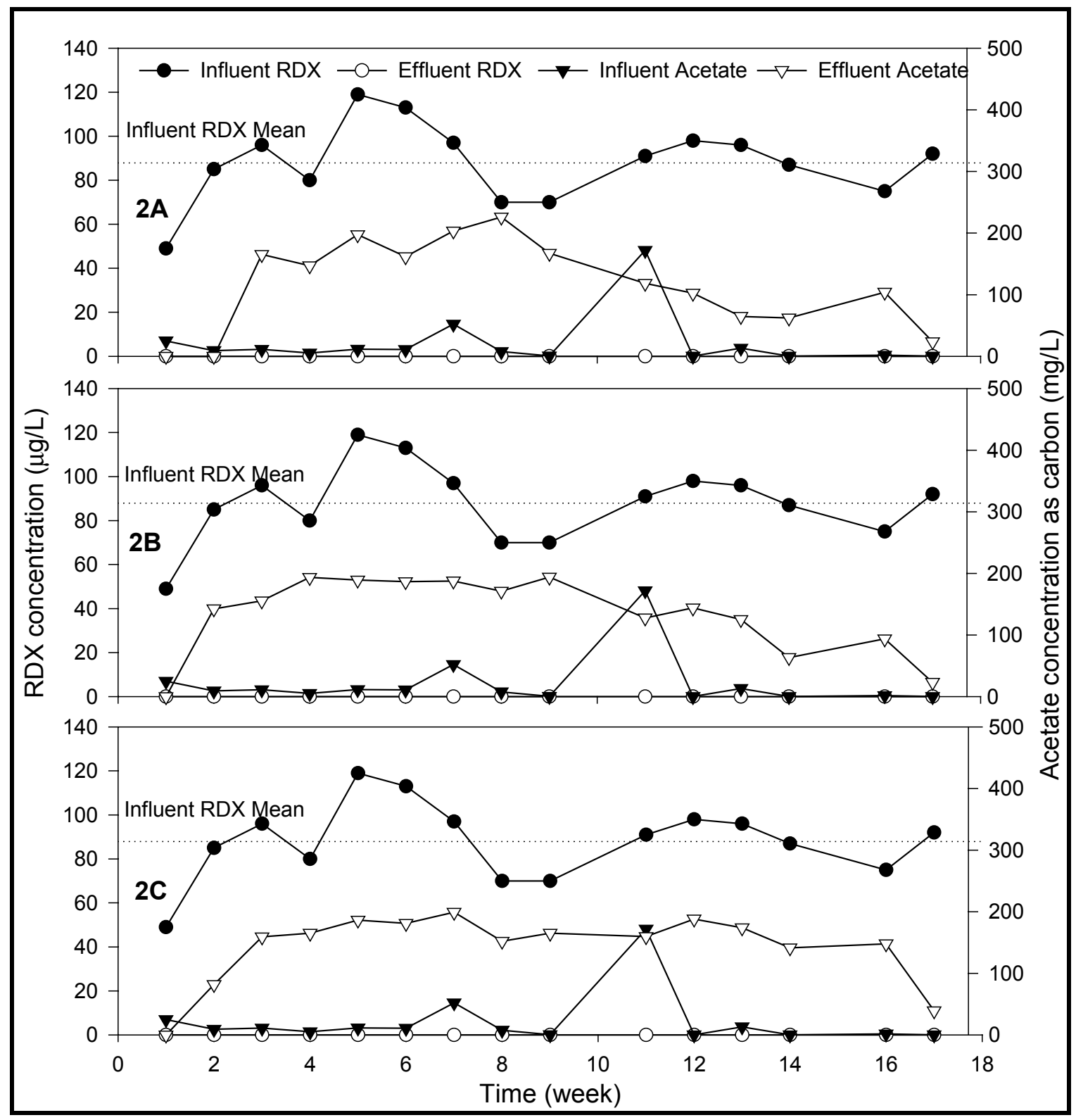

Figure B32. RDX removal from NOP groundwater amended with ethanol (Ethanol concentration $=500 \mathrm{mg} \mathrm{L}^{-1}$ as $\mathrm{C}$ ) 


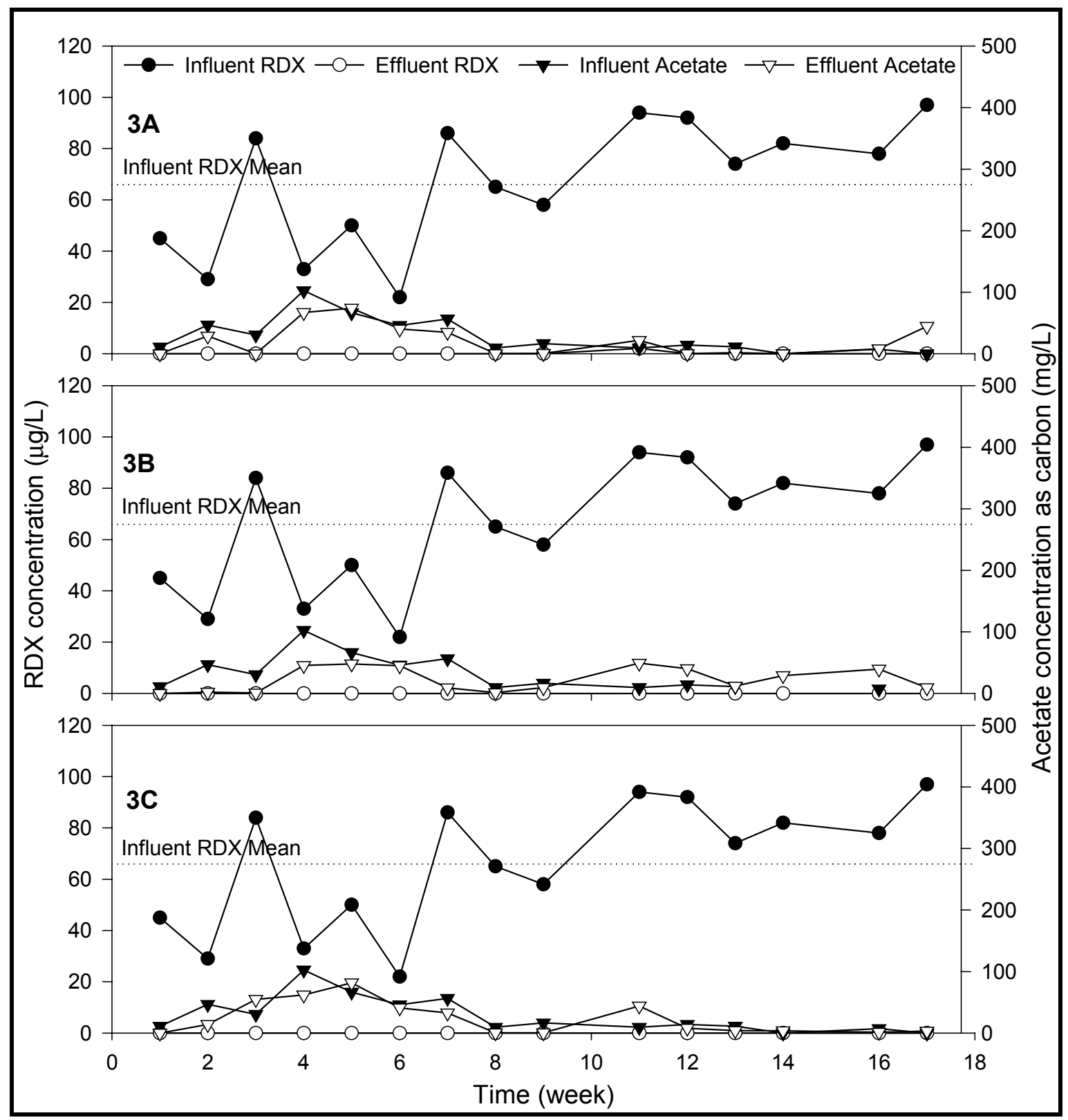

Figure B33. RDX removal from NOP groundwater amended with soluble starch (Starch concentration $=500 \mathrm{mg} \mathrm{L}^{-1}$ as C) 


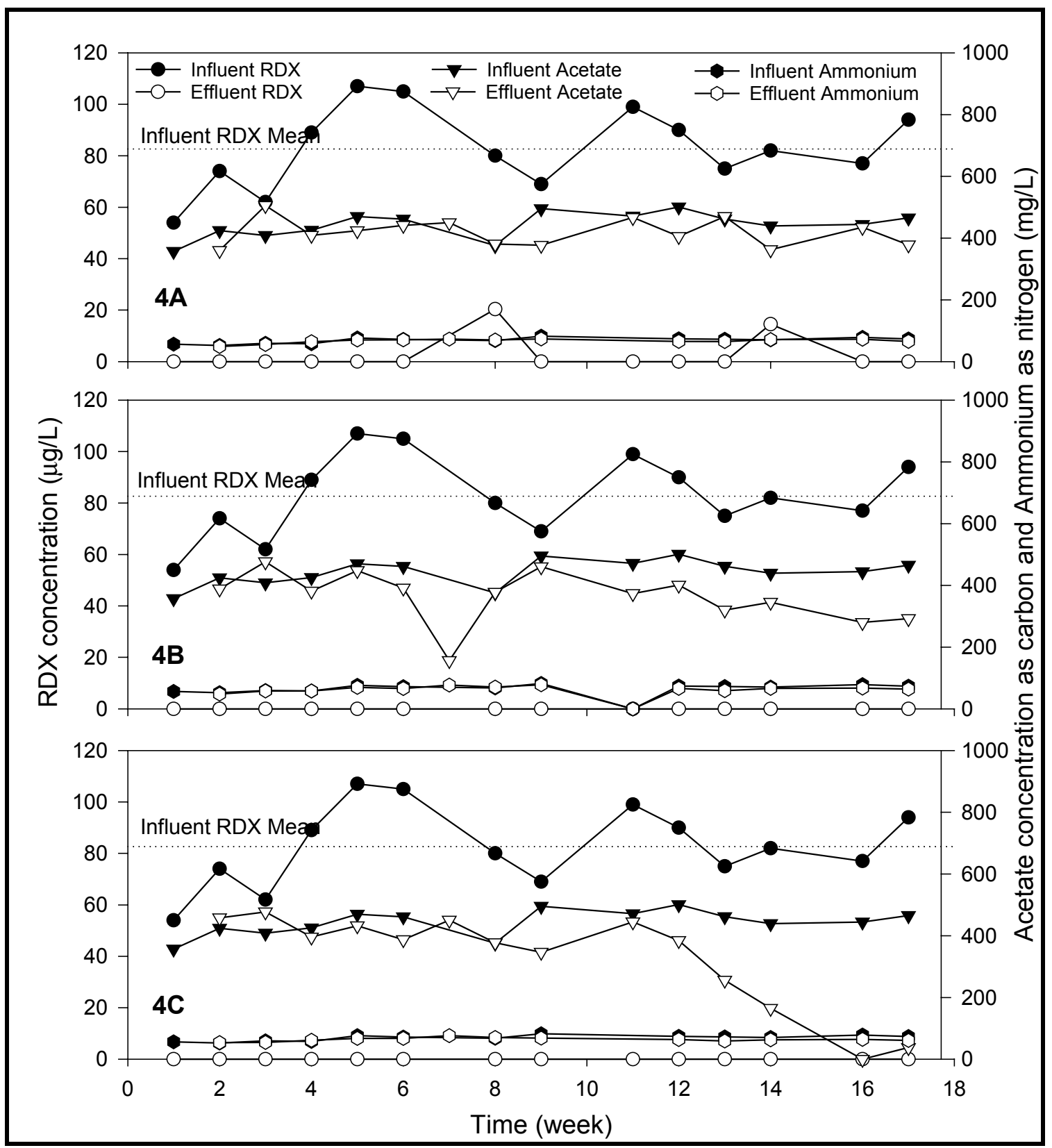

Figure B34. RDX removal from NOP groundwater amended with acetate and ammonium Acetate concentration $=500 \mathrm{mg} \mathrm{L}^{-1}$ as $\mathrm{C}$, ammonium concentration $=100 \mathrm{mg} \mathrm{L}^{-1}$ as $\mathrm{N}$ ) 


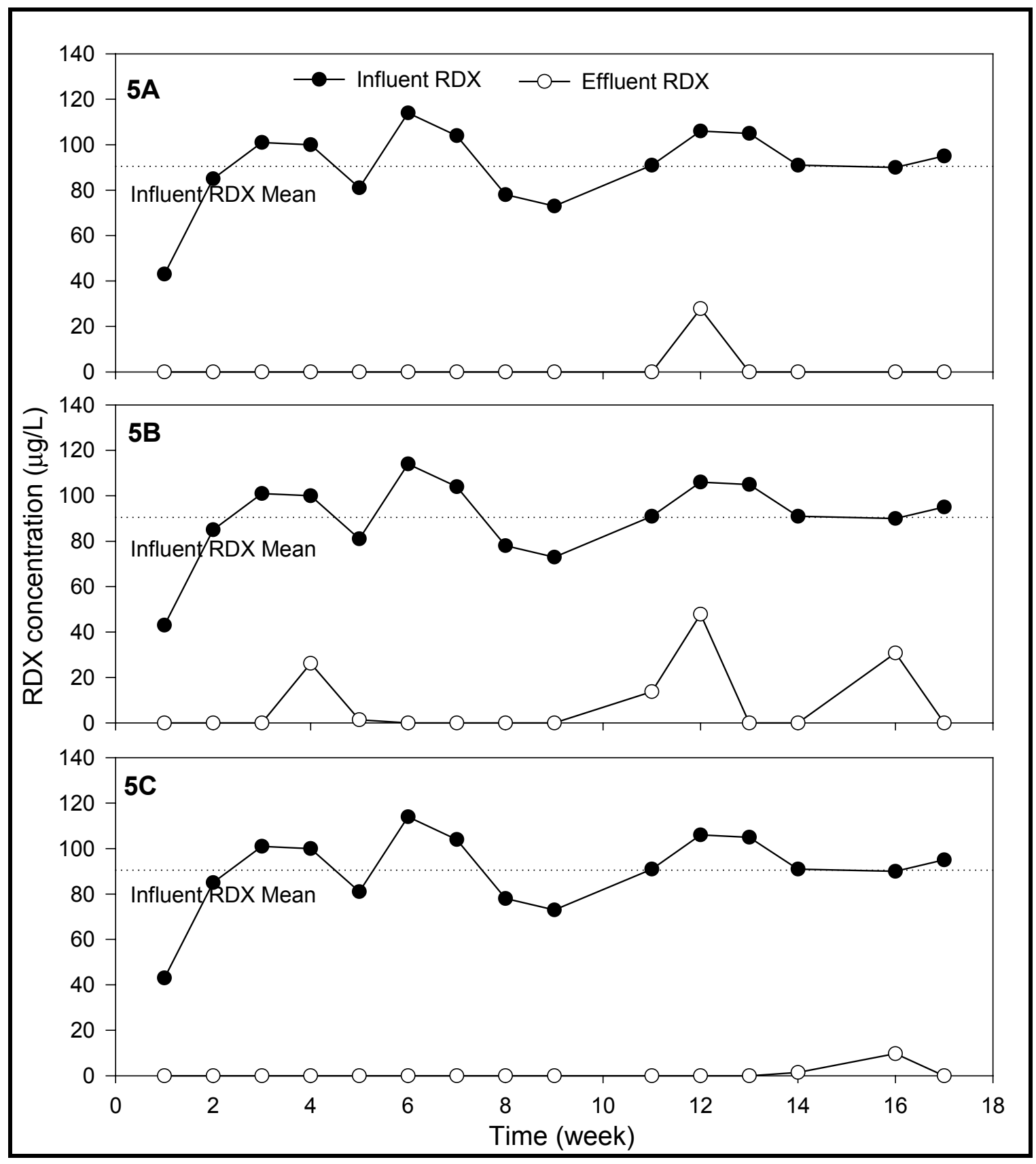

Figure B35. RDX removal from NOP groundwater without amendment 


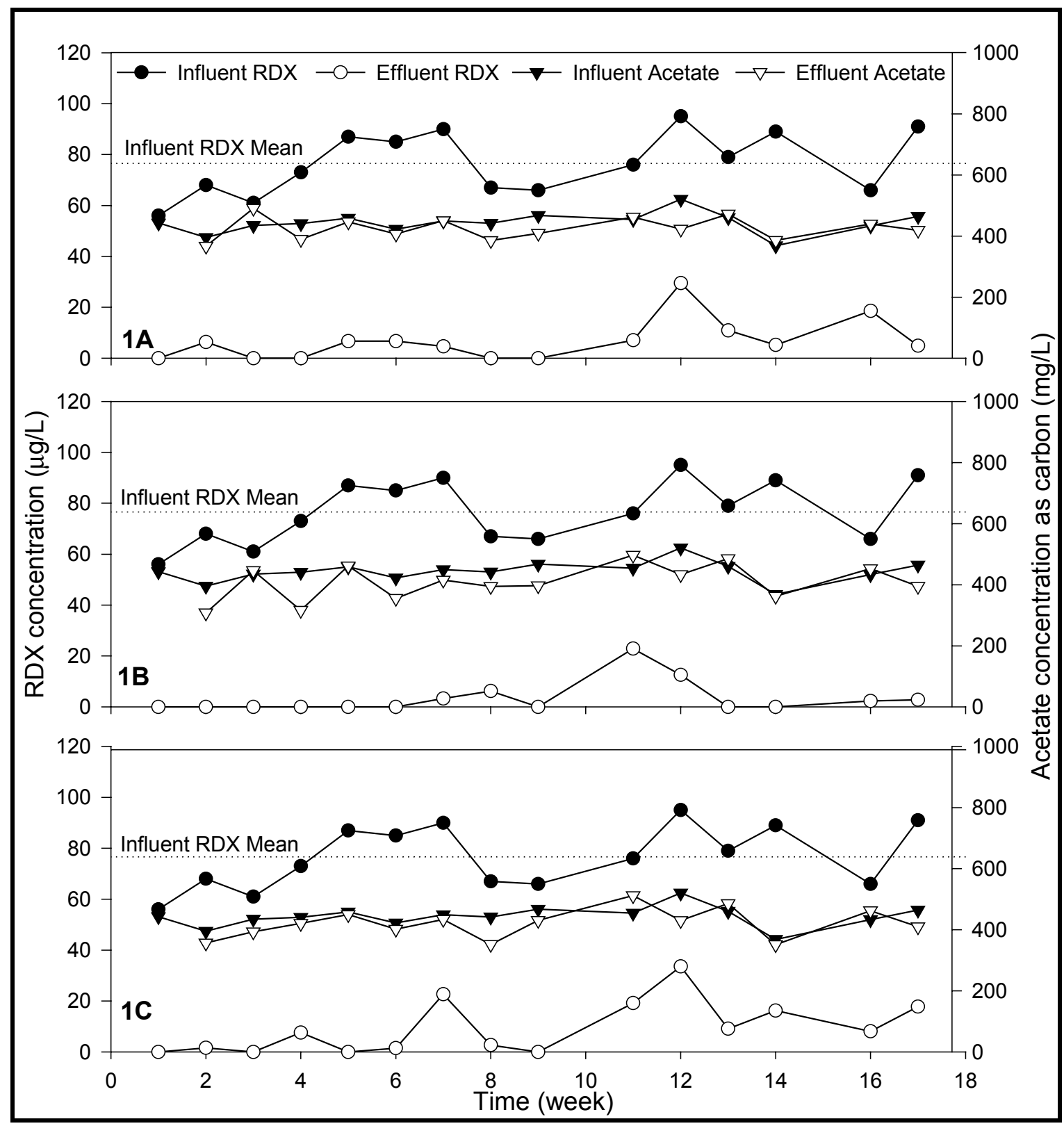

Figure B36. RDX removal from CHAAP groundwater amended with acetate (Acetate concentration $=500 \mathrm{mg} \mathrm{L}^{-1}$ as C) 


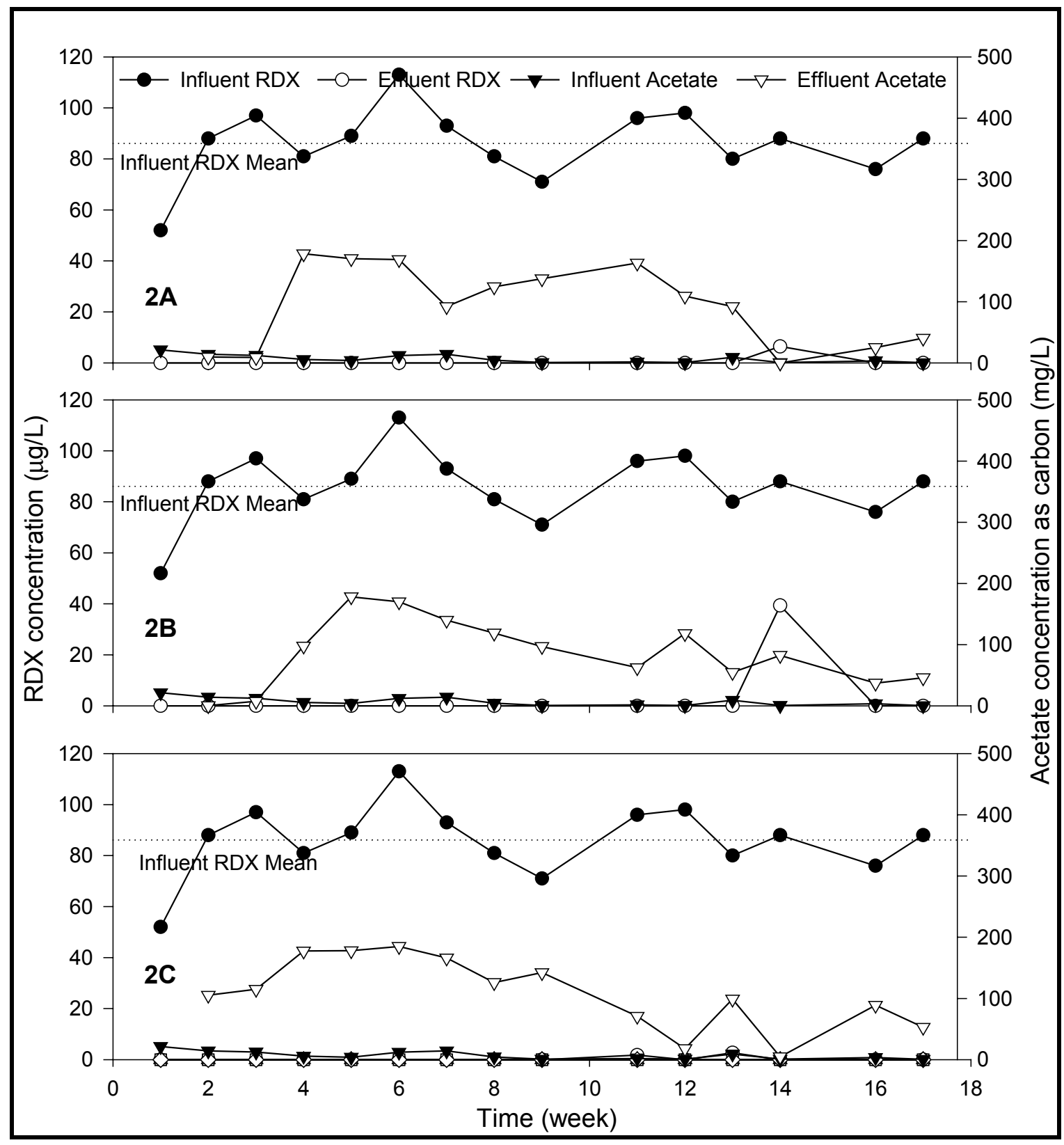

Figure B37. RDX removal from CHAAP groundwater amended with ethanol (Ethanol concentration $=500 \mathrm{mg} \mathrm{L}^{-1}$ as $\mathrm{C}$ ) 


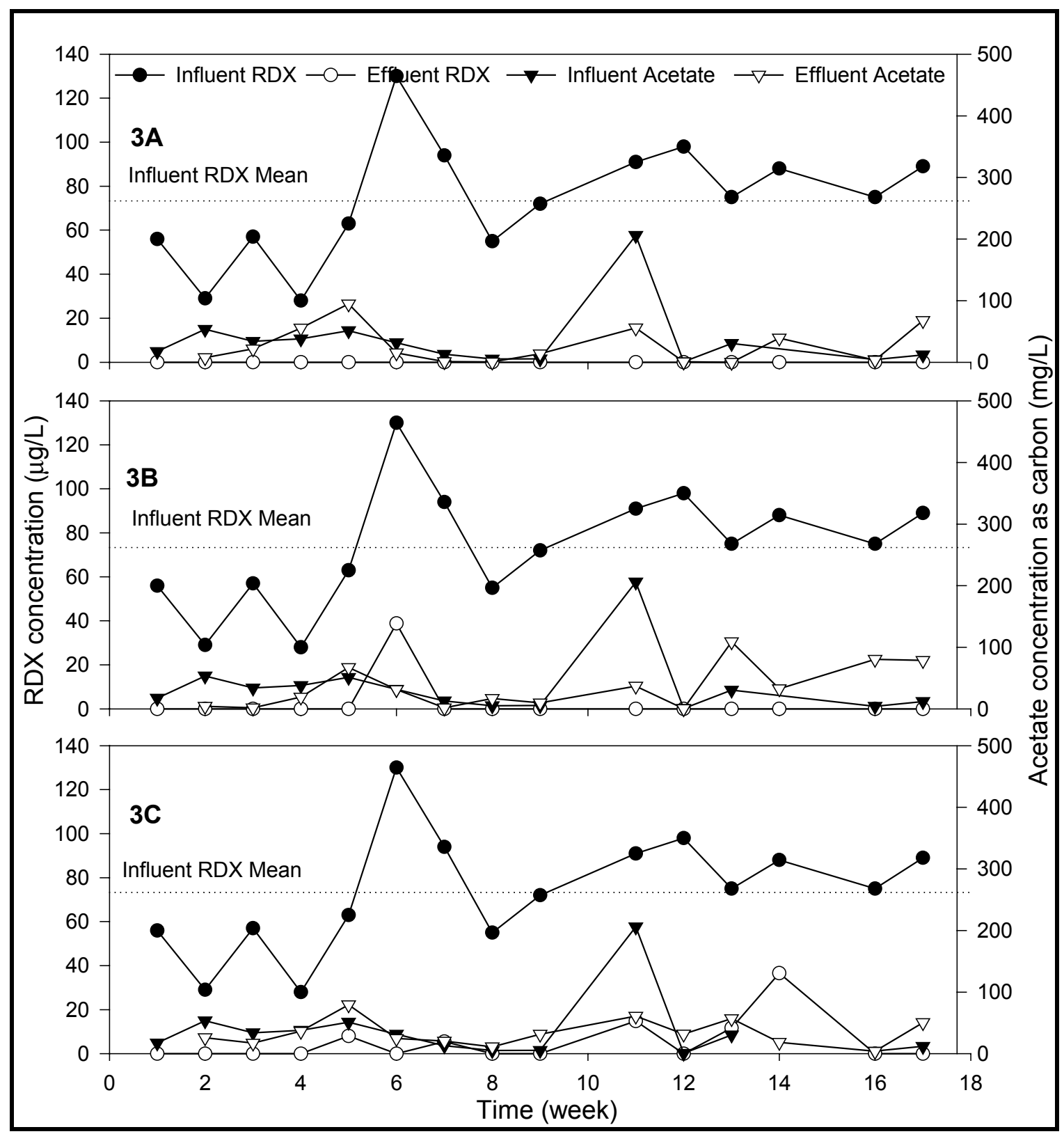

Figure B38. RDX removal from CHAAP groundwater amended with soluble starch (Starch concentration $=500 \mathrm{mg} \mathrm{L}^{-1}$ as C) 


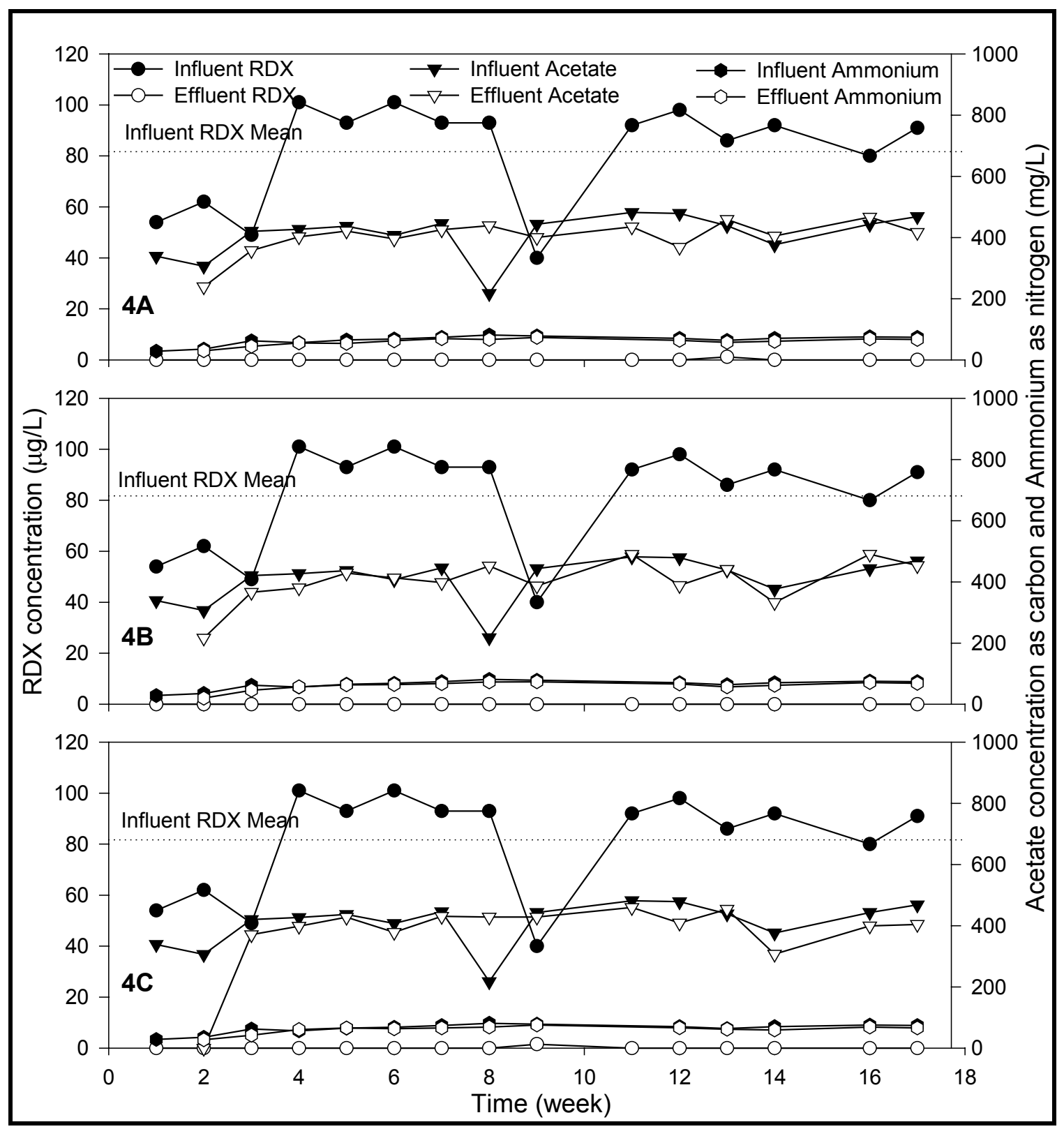

Figure B39. RDX removal from CHAAP groundwater amended with acetate and ammonium (Acetate concentration $=500 \mathrm{mg} \mathrm{L}^{-1}$ as $\mathrm{C}$, ammonium concentration $=100 \mathrm{mg} \mathrm{L}^{-1}$ as $\mathrm{N}$ ) 


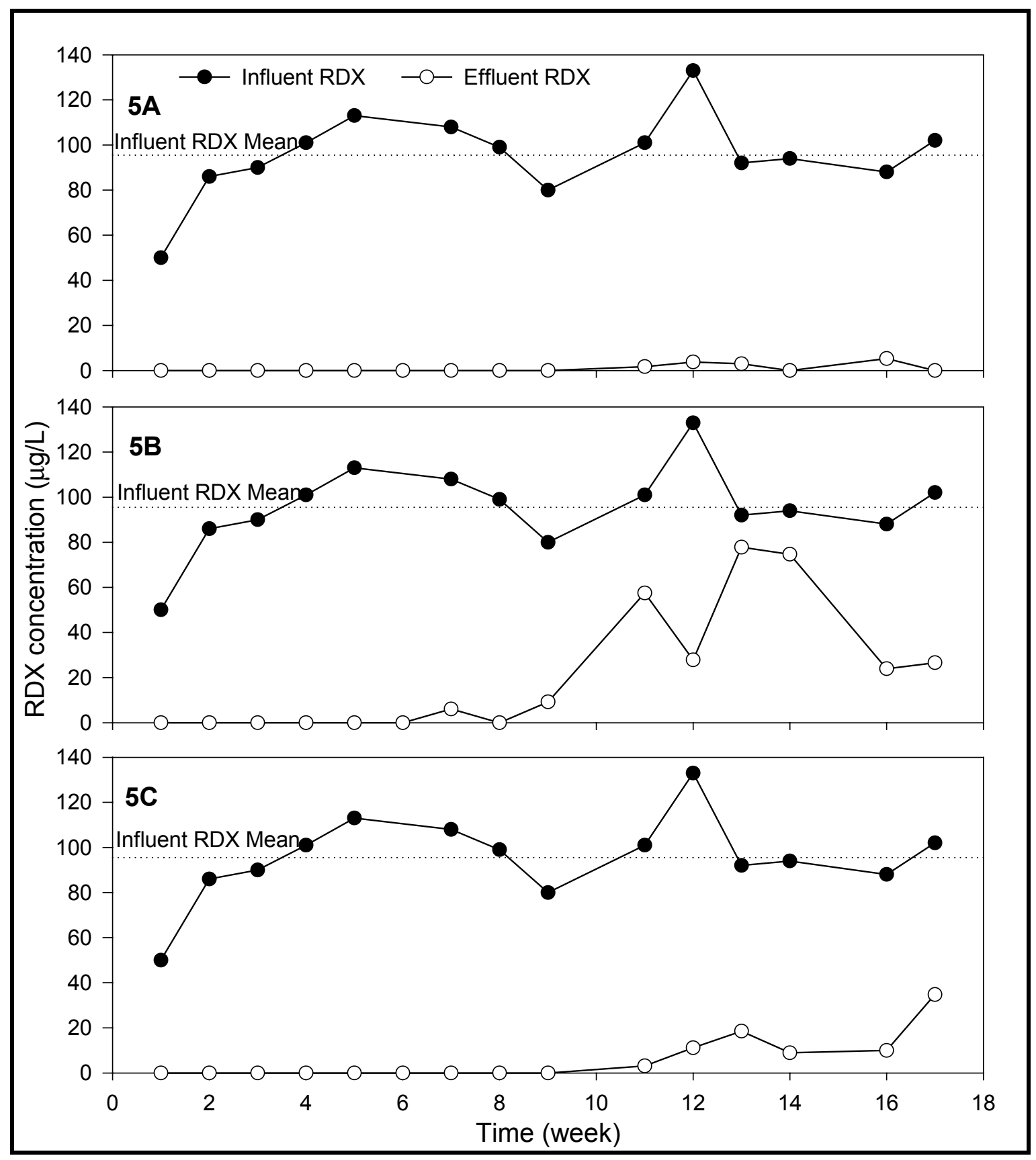

Figure B40. RDX removal from CHAAP groundwater without amendment 


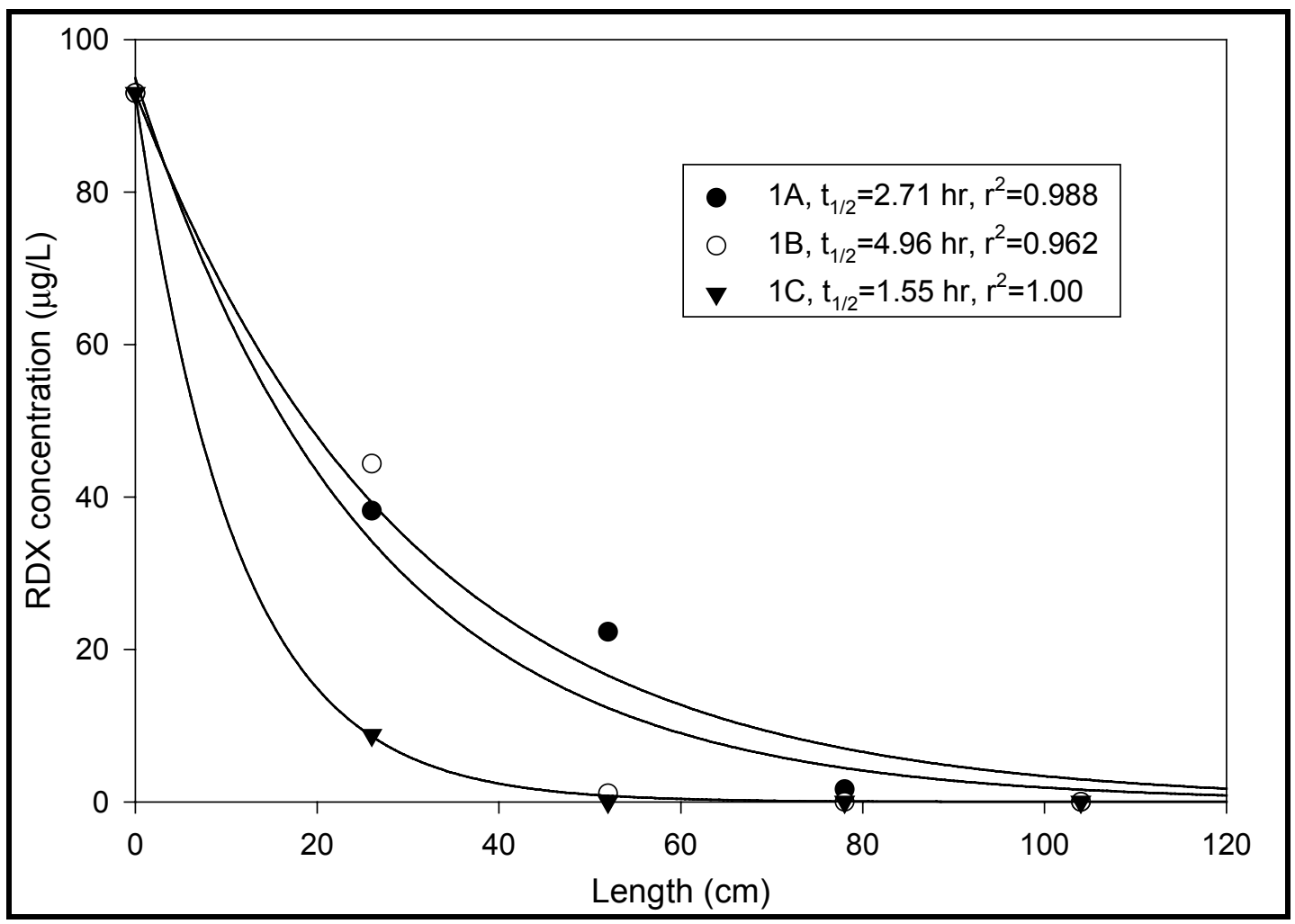

Figure B41. RDX biodegradation kinetics in NOP aquifer material (Column Set \#1)

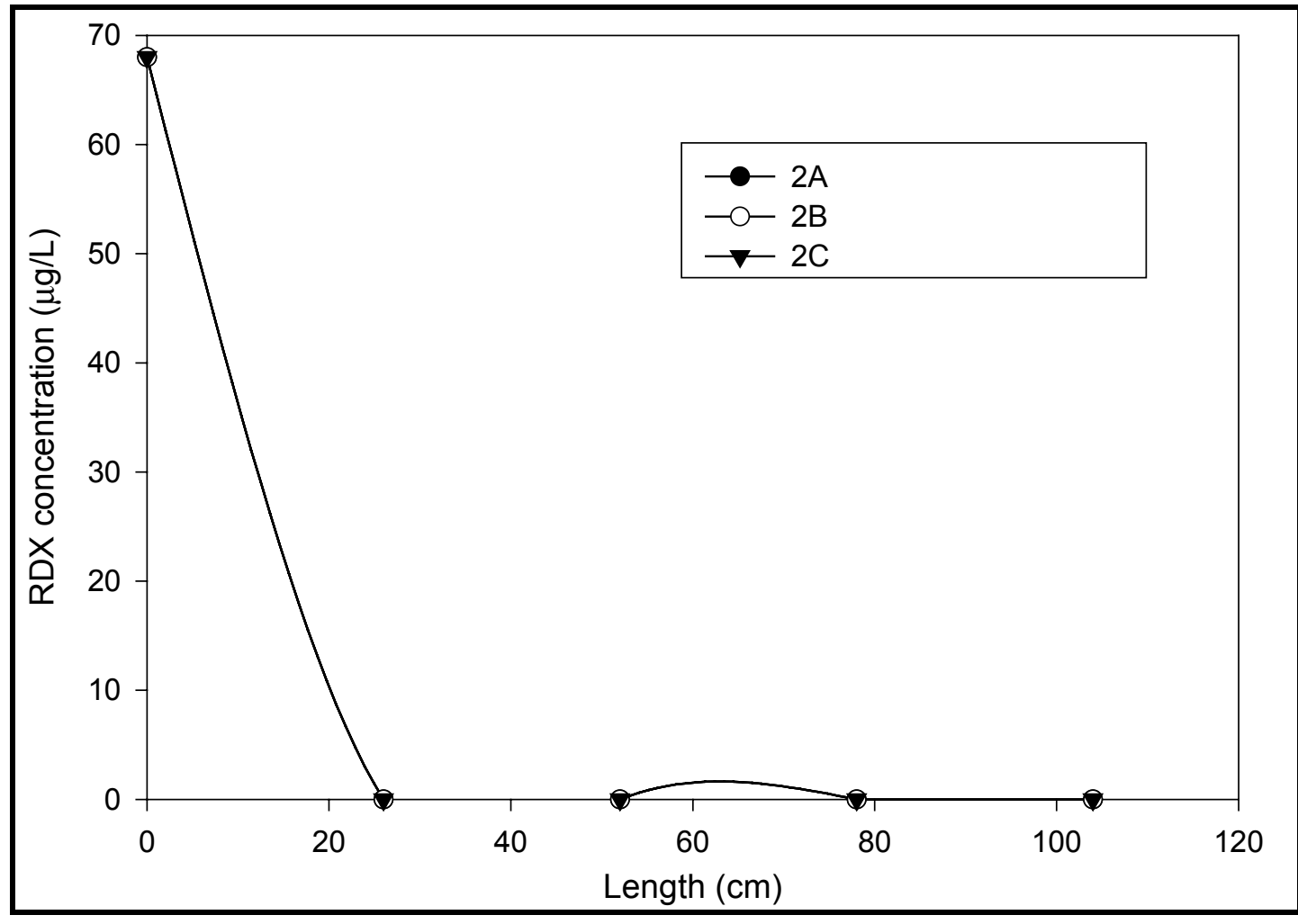

Figure B42. RDX biodegradation kinetics in NOP aquifer material (Column Set \#2) 


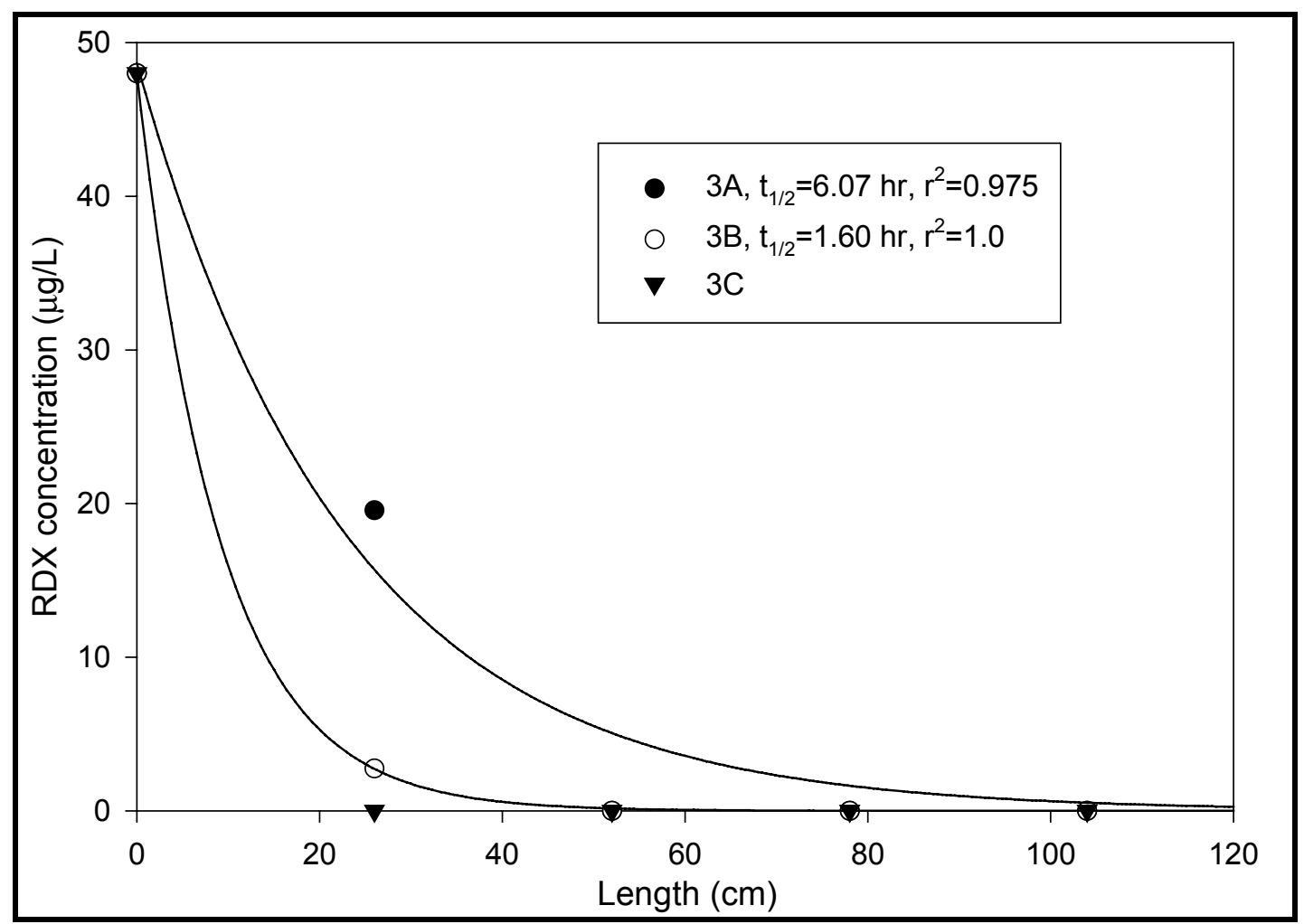

Figure B43. RDX biodegradation kinetics in NOP aquifer material (Column Set \#3)

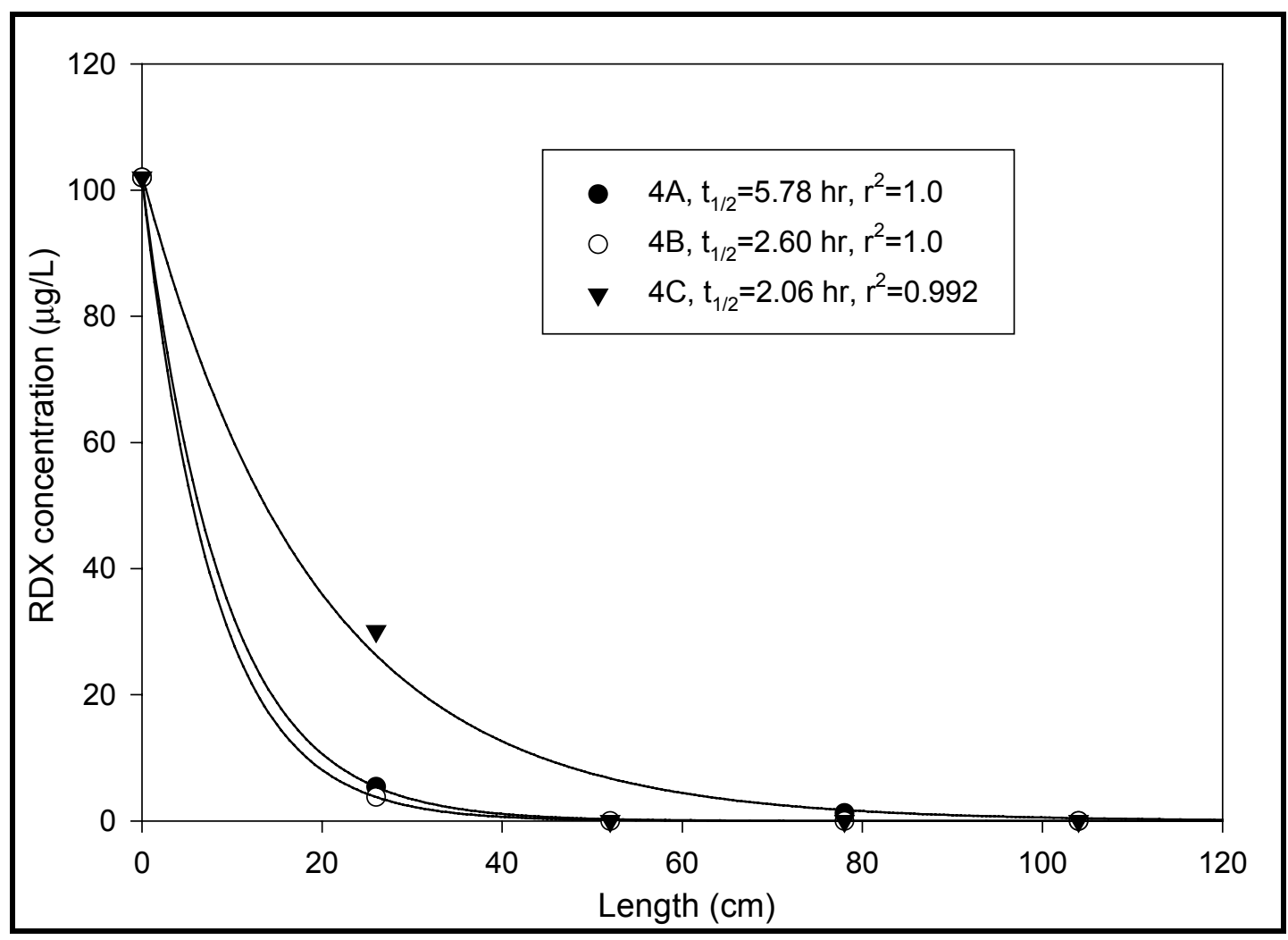

Figure B44. RDX biodegradation kinetics in NOP aquifer material (Column Set \#4) 


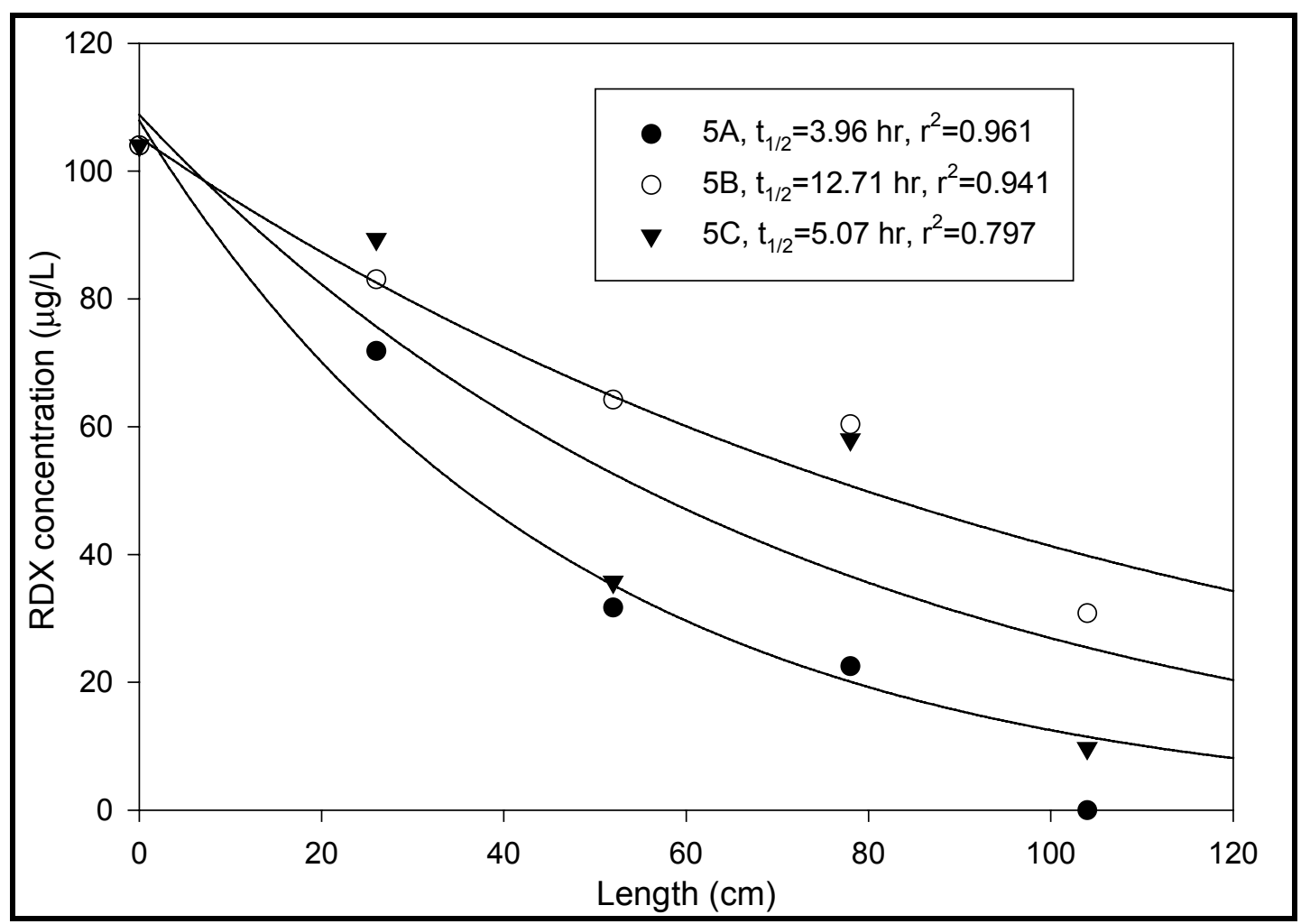

Figure B45. RDX biodegradation kinetics in NOP aquifer material (Column Set \#5)

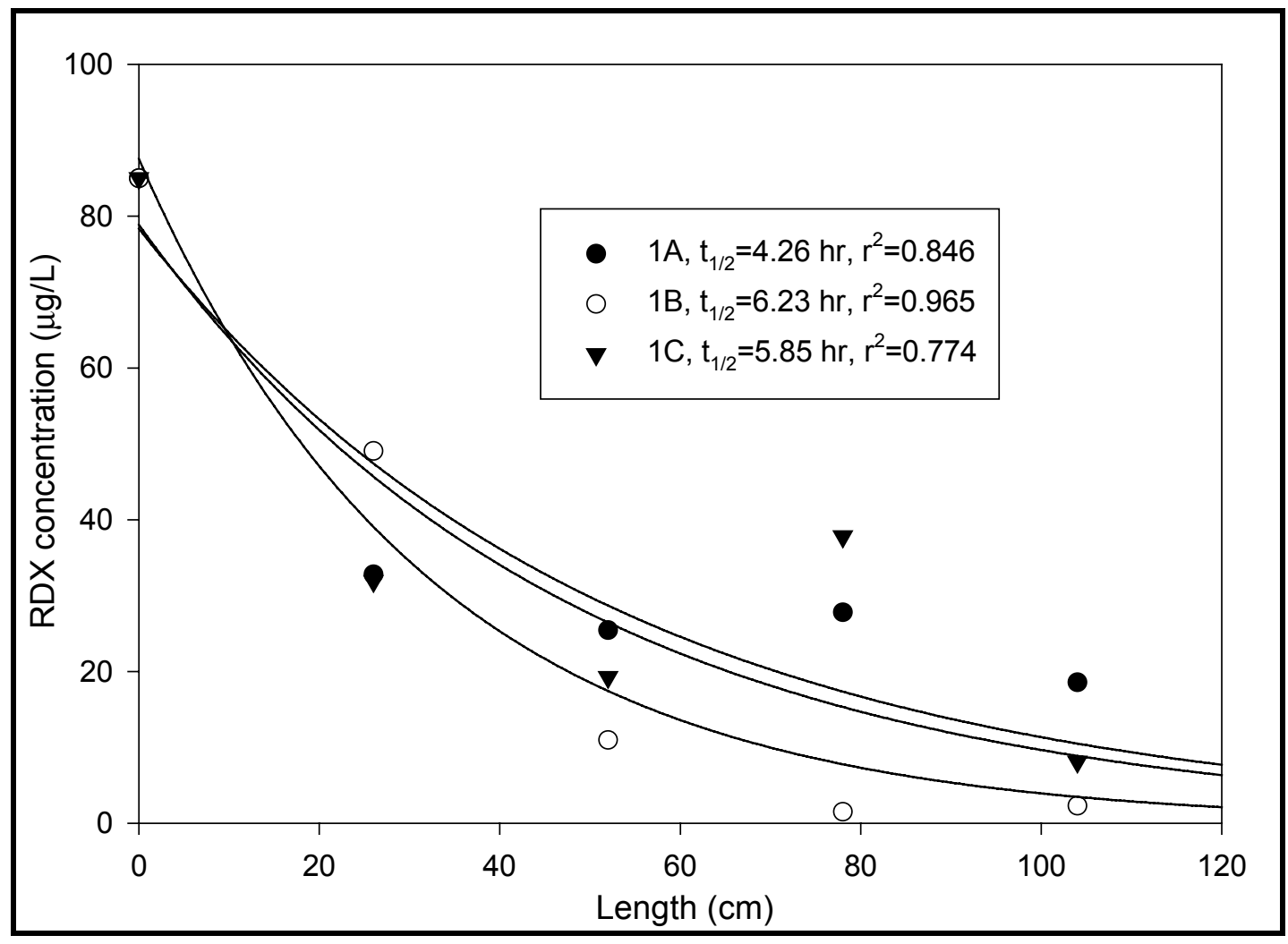

Figure B46. RDX biodegradation kinetics in CHAAP aquifer material (Column Set \#1) 


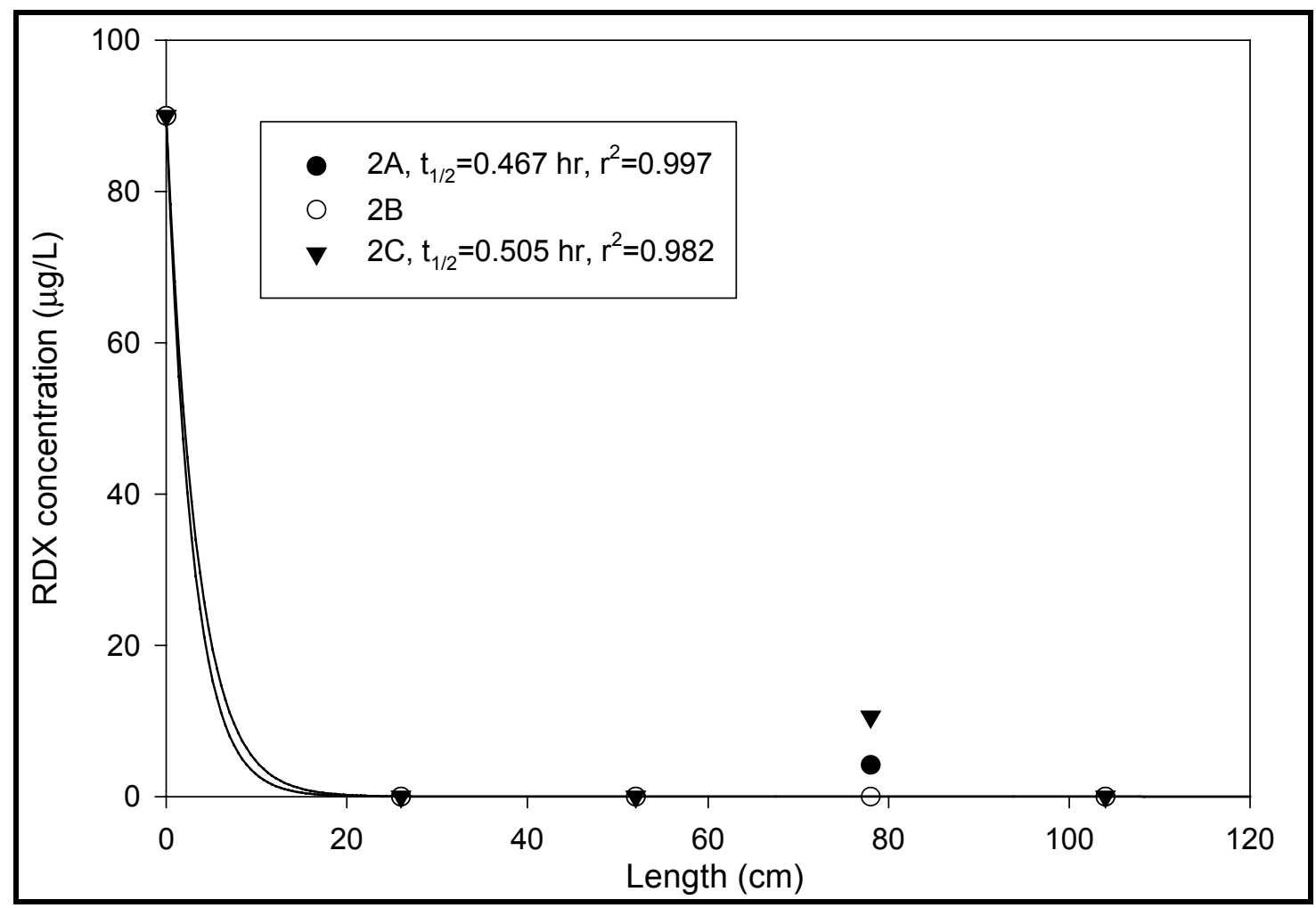

Figure B47. RDX biodegradation kinetics in CHAAP aquifer material (Column Set \#2)

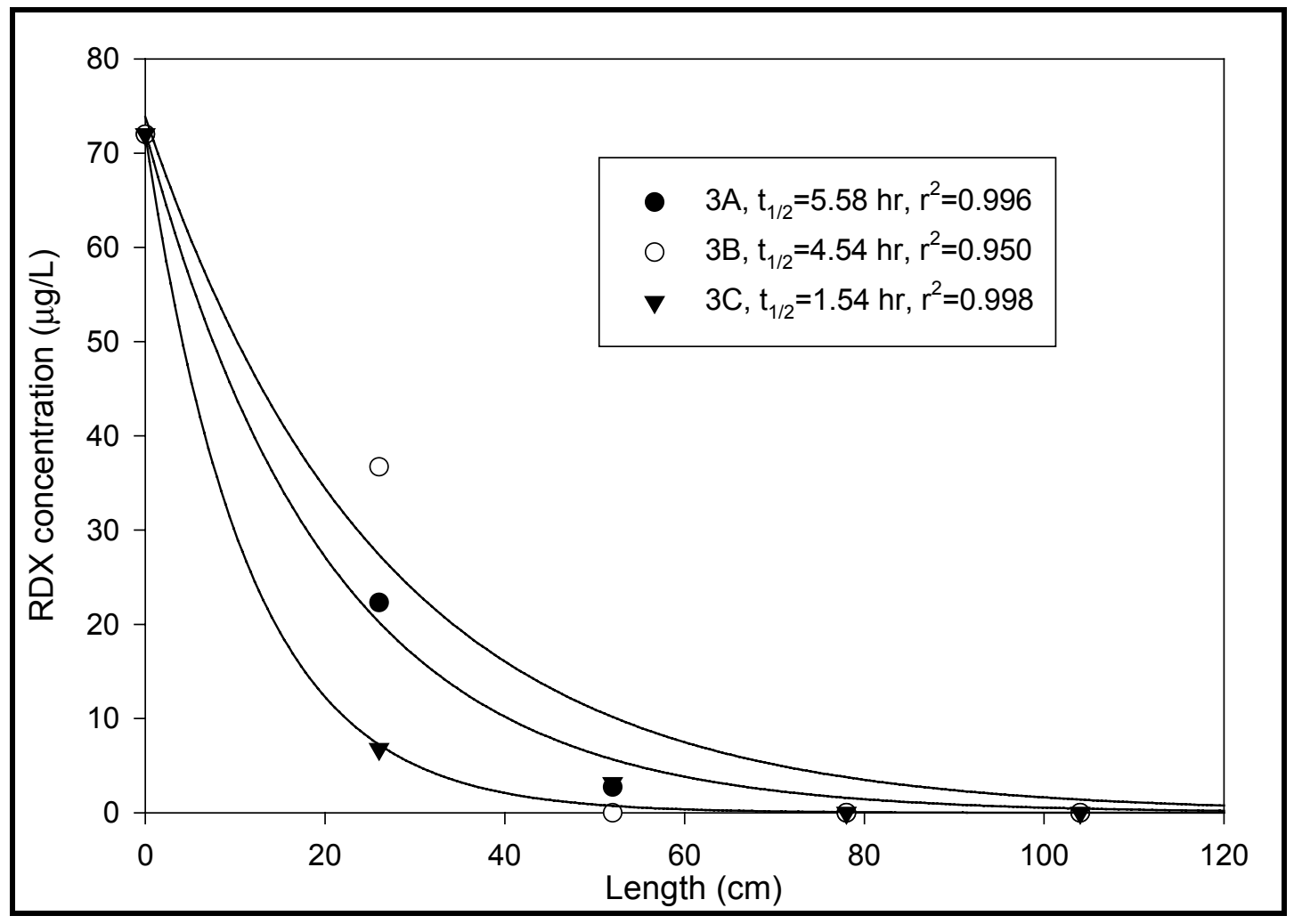

Figure B48. RDX biodegradation kinetics in CHAAP aquifer material (Column Set \#3) 


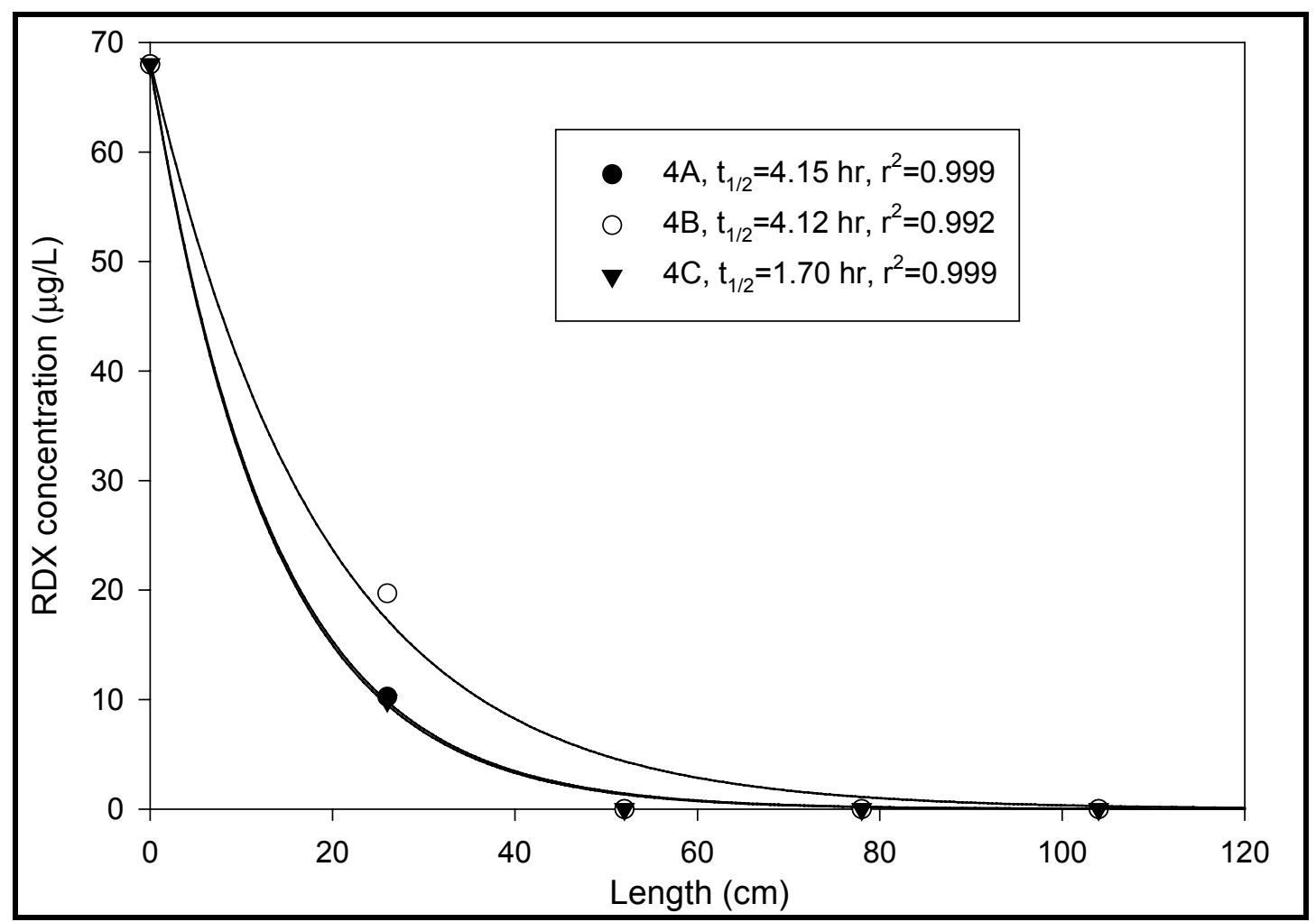

Figure B49. RDX biodegradation kinetics in CHAAP aquifer material (Column Set \#4)

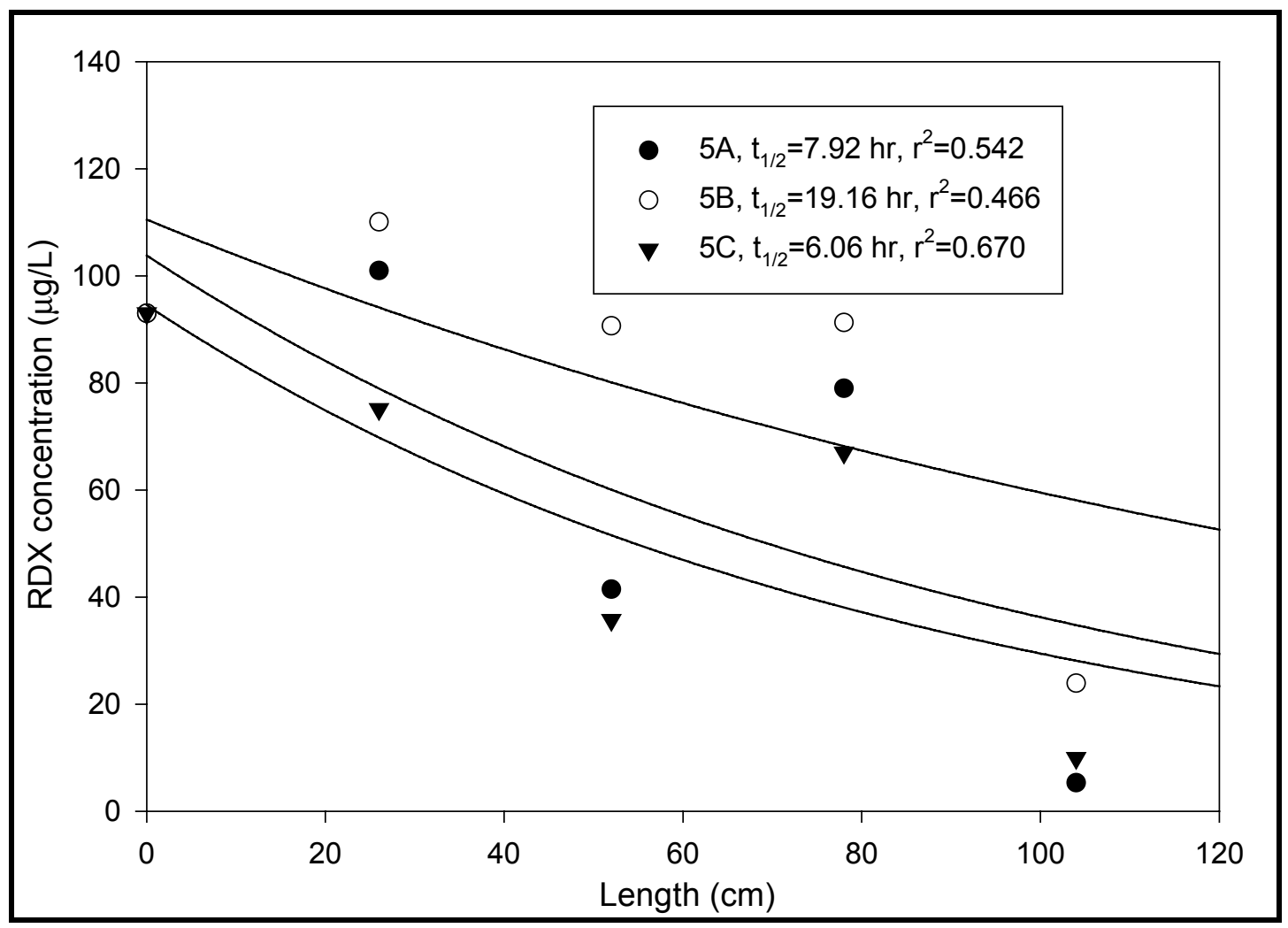

Figure B50. RDX biodegradation kinetics in CHAAP aquifer material (Column Set \#5) 


\begin{tabular}{|c|c|c|}
\hline \multicolumn{2}{|c|}{ REPORT DOCUMENTATION PAGE } & $\begin{array}{c}\text { Form Approved } \\
\text { OMB No. 0704-0188 }\end{array}$ \\
\hline \multicolumn{3}{|c|}{ 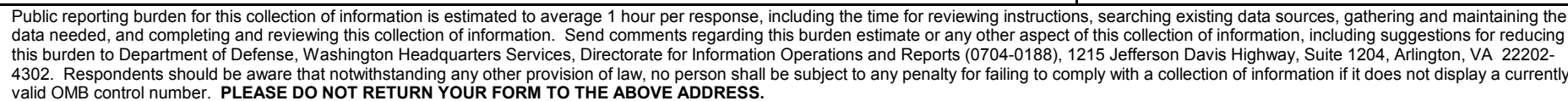 } \\
\hline $\begin{array}{l}\text { 1. REPORT DATE } \\
\text { October } 2002\end{array}$ & $\begin{array}{l}\text { 2. REPORT TYPE } \\
\text { Final report }\end{array}$ & 3. DATES COVERED (From - To) \\
\hline \multirow{3}{*}{\multicolumn{2}{|c|}{$\begin{array}{l}\text { 4. TITLE AND SUBTITLE } \\
\text { Treatability Study for Biologically Active Zone Enhancement (BAZE) for In Situ RDX } \\
\text { Degradation in Groundwater }\end{array}$}} & 5a. CONTRACT NUMBER \\
\hline & & 5b. GRANT NUMBER \\
\hline & & 5c. PROGRAM ELEMENT NUMBER \\
\hline \multirow{3}{*}{\multicolumn{2}{|c|}{$\begin{array}{l}\text { 6. AUTHOR(S) } \\
\text { Altaf H. Wani, Brenda R. O’Neal, Jeffrey L. Davis, Lance D. Hansen }\end{array}$}} & 5d. PROJECT NUMBER \\
\hline & & 5e. TASK NUMBER \\
\hline & & 5f. WORK UNIT NUMBER \\
\hline \multicolumn{2}{|c|}{$\begin{array}{l}\text { 7. PERFORMING ORGANIZATION NAME(S) AND ADDRESS(ES) } \\
\text { Applied Research Associates, Inc. } \\
112 \text { Monument Place, Vicksburg, MS } 39180 \\
\text { U.S. Army Engineer Research and Development Center } \\
\text { Environmental Laboratory } \\
3909 \text { Halls Ferry Road, Vicksburg, MS 39180-6199 }\end{array}$} & $\begin{array}{l}\text { 8. PERFORMING ORGANIZATION REPORT } \\
\text { NUMBER } \\
\text { ERDC/EL TR-02-35 }\end{array}$ \\
\hline \multirow{2}{*}{\multicolumn{2}{|c|}{$\begin{array}{l}\text { 9. SPONSORING / MONITORING AGENCY NAME(S) AND ADDRESS(ES) } \\
\text { U.S. Army Corps of Engineers } \\
\text { Washington, DC 20314-1000 }\end{array}$}} & 10. SPONSOR/MONITOR'S ACRONYM(S) \\
\hline & & $\begin{array}{l}\text { 11. SPONSOR/MONITOR'S REPORT } \\
\text { NUMBER(S) }\end{array}$ \\
\hline \multicolumn{3}{|c|}{$\begin{array}{l}\text { 12. DISTRIBUTION / AVAILABILITY STATEMENT } \\
\text { Approved for public release; distribution is unlimited. }\end{array}$} \\
\hline \multicolumn{3}{|c|}{ 13. SUPPLEMENTARY NOTES } \\
\hline \multicolumn{3}{|c|}{$\begin{array}{l}\text { 14. ABSTRACT } \\
\text { The work reported here is the first phase of a 4-year field demonstration project under DoD's Environmental Security Technology } \\
\text { Certification Program (ESTCP). The purpose of this treatability study was to determine the suitability of two formerly used Federal } \\
\text { ordnance facilities (Nebraska Ordnance Plant and Cornhusker Army Ammunition Plant) for pilot-scale demonstration/validation of in situ } \\
\text { bioremediation of hexahydro-1,3,5-trinitro-1,3,5-triazine (RDX) contaminated groundwater. A series of column studies were conducted } \\
\text { using site-specific soil and groundwater to determine the feasibility of using the biologically active zone enhancement (BAZE) process with } \\
\text { indigenous microbial population to remediate RDX-contaminated groundwater. This treatability study examined the use of four } \\
\text { amendments (acetate, ethanol, soluble starch, and acetate plus ammonium) as electron donors. All the amendments studied were able to } \\
\text { achieve the necessary reducing conditions for remediating RDX inlet concentration of } 100 \mathrm{ppb} \text { to less than } 1 \text { ppb. The addition of some } \\
\text { amendments resulted in increased toxicity based on Microtox analysis. Ethanol addition itself did not result in increased toxicity, but } \\
\text { biological activity in this system did induce high toxicity. The addition of soluble starch resulted in increased toxicity that was partially } \\
\text { removed by biological activity in the columns. The addition of ammonium as a nitrogen source did not significantly increase the removal } \\
\text { rate of RDX. Based on these observations, acetate was chosen to be used in the field evaluation. }\end{array}$} \\
\hline
\end{tabular}

\begin{tabular}{|c|c|c|c|c|c|c|}
\hline \multicolumn{7}{|l|}{ 15. SUBJECT TERMS } \\
\hline \multicolumn{3}{|c|}{ 16. SECURITY CLASSIFICATION OF: } & & $\begin{array}{l}\text { MITATION } \\
\text { STRACT }\end{array}$ & $\begin{array}{l}\text { 18. NUMBER } \\
\text { OF PAGES }\end{array}$ & 19a. NAME OF RESPONSIBLE PERSON \\
\hline $\begin{array}{l}\text { a. REPORT } \\
\text { UNCLASSIFIED }\end{array}$ & $\begin{array}{l}\text { b. ABSTRACT } \\
\text { UNCLASSIFIED }\end{array}$ & $\begin{array}{l}\text { c. THIS PAGE } \\
\text { UNCLASSIFIED }\end{array}$ & & & 89 & $\begin{array}{l}\text { 19b. TELEPHONE NUMBER (include area } \\
\text { code) }\end{array}$ \\
\hline
\end{tabular}

